\title{
O INSTITUTO DO BENEFÍCIO PARTICULAR NAS ASSEMBLEIAS GERAIS DE SOCIEDADES ANÔNIMAS
}

DEPARTAMENTO DE DIREITO COMERCIAL

ORIENTADOR: PROFESSOR Dr. FRANCISCO SATIRO DE SOUZA JUNIOR

Dissertação de Mestrado a ser apresentada ao Departamento de Direito Comercial da Faculdade de Direito da Universidade de São Paulo.

FACULDADE DE DIREITO-UNIVERSIDADE DE SÃO PAULO-

\author{
SÃo PAULO
}

2013 


\title{
O INSTITUTO DO BENEFÍCIO PARTICULAR NAS ASSEMBLEIAS GERAIS DE SOCIEDADES ANÔNIMAS
}

\author{
DEPARTAMENTO DE DIREITO COMERCIAL
}

ORIENTADOR: PROFESSOR Dr. FRANCISCO SATIRO DE SOUZA JUNIOR

Dissertação de Mestrado a ser apresentada ao Departamento de Direito Comercial da Faculdade de Direito da Universidade de São Paulo.

FACULDADE DE DIREITO-UNIVERSIDADE DE SÃO PAULO-

\author{
SÃO PAULO
}

2013 
NICOLAS CÉSAR JULIANO BUTROS PRESTES NICOLIELO

\section{O INSTITUTO DO BENEFÍCIO PARTICULAR NAS ASSEMBLEIAS GERAIS DE SOCIEDADES ANÔNIMAS}

DEPARTAMENTO DE DIREITO COMERCIAL

ORIENTADOR: PROFESSOR Dr. FRANCISCO SATIRO DE SOUZA JUNIOR

Dissertação de Mestrado a ser apresentada ao Departamento de Direito Comercial da Faculdade de Direito da Universidade de São Paulo.

DATA

BANCA EXAMINADORA 
Aos meus pais, por tudo que sou.

À querida esposa Fernanda, pelo amor incondicional e compreensão.

À minha amada filha Maria Luiza, que mesmo ainda nascitura, já é a razão da minha vida. 


\section{AGRADECIMENTOS}

Agradeço a Deus, razão de toda a existência.

Agradeço ao Professor Dr. Francisco Satiro de Souza Jr., meu orientador, por acreditar em meu trabalho e pelas valiosas instruções.

Agradeço ao amigo Dr. Ricardo de Santos Freitas, por me apresentar efetivamente ao Direito Comercial e ao mundo das assembleias das sociedades anônimas, pelas enriquecedoras discussões, bem como pelo incentivo sempre presente.

Agradeço a todos os meus colegas do escritório Freitas Leite Advogados, sobretudo ao Dr. Raul de Paula Leite Filho e ao Dr. Cristiano da Cruz Leite, pelo incentivo e compreensão.

Agradeço à amiga Sarah, pelo precioso auxílio na reta final do presente trabalho.

Agradeço à minha esposa Fernanda e meus pais, pelo apoio constante.

E também agradeço a todos aqueles que, de uma forma ou de outra, contribuíram ou estiveram envolvidos com a realização deste trabalho. 


\section{SUMÁRIO}

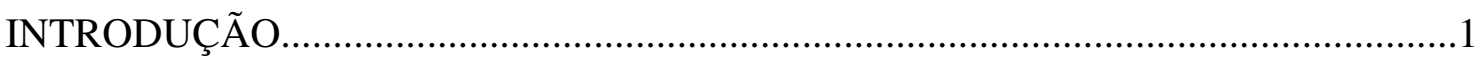

CAP. 1- O BENEFÍCIO PARTICULAR: ORIGENS, CONCEITUAÇÃO, EFEITOS E

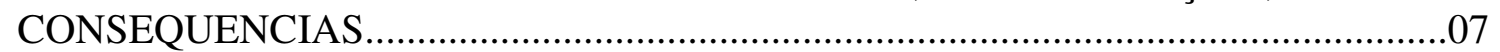

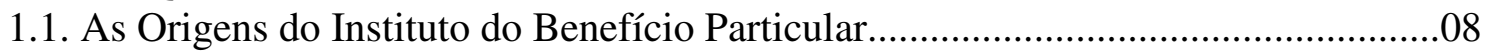

1.1.1. As Origens do Instituto do Benefício Particular na França...................................08

1.1.2. As Origens do Instituto do Benefício Particular na Alemanha................................14

1.1.3. As Origens do Instituto do Benefício Particular no Brasil...................................17

1.2. A Conceituação do Instituto do Benefício Particular...............................................19

1.2.1. O Benefício Particular como Vantagem Lícita.....................................................19

1.2.2. O Benefício Particular como Vantagem Exclusiva e Restrita que Rompe a Igualdade entre os Acionistas $\mathrm{e}$ o Preceito Nemo Iudex In Causa

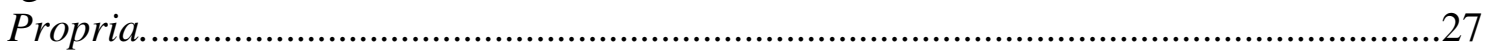

1.2.3. O Benefício Particular como Ato de Liberalidade de Natureza Pecuniária que

Rompe com o Interesse Comum dos Acionistas............................................................33

1.2.4. Conclusões sobre a Conceituação do Benefício Particular...................................43

1.3. Efeitos do Benefício Particular: O impedimento de Voto..........................................44

1.4. Consequências da Violação à Regra Legal..........................................................50

CAP. 2 - O CONFLITO DE INTERESSES E O BENEFÍCIO PARTICULAR:

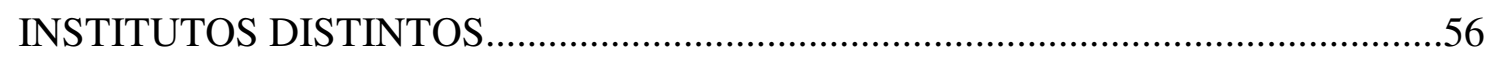

2.1. O Conflito de Interesse nas Assembleias Gerais de Acionistas...............................57

2.1.1. O Interesse Social..........................................................................................60

2.1.1.1. O Interesse Social e a Orientação de Voto das Assembleias de Sociedades Anônimas. .68

2.1.2. O Conflito de Interesses: Evolução Legislativa Comparada e a Exegese do $§ 1^{\circ}$ do

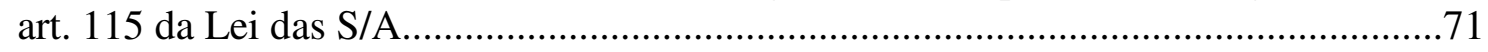

2.1.3. O Conflito de Interesse: A Vantagem Ilícita...........................................................79

2.2. O Conflito de Interesse e o Benefício Particular: Semelhanças e Diferenças...........80

CAP. 3 - APLICAÇÕES PRÁTICAS DO BENEFÍCIO PARTICULAR: A

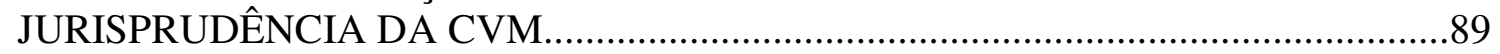

3.1 Transações com Partes Relacionadas......................................................................99

3.2. Incorporação de Ações de Companhias Controladas e sob Controle Comum e o Parecer de Orientação CVM n. 34................................................................................105

3.3. Redução do Valor Nominal das Ações com Implicações no Recebimento do Dividendo Mínimo Obrigatório e Condições para Resgate de Ações............................135

3.4. Redução de Deságio de Crédito de Acionista a ser Integralizado em Aumento de Capital..... .140

3.5. Cancelamento de Dívida de Acionista Contra a Companhia.................................144

3.6 Concessão de Bonificação a Acionistas com Implicações no Aumento da Participação do Acionista Controlador em Reorganização Societária...........................146

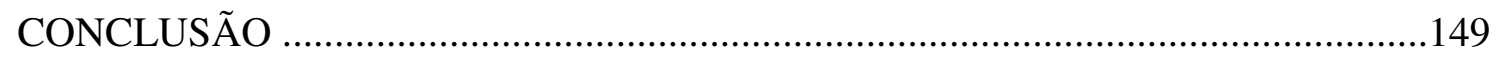

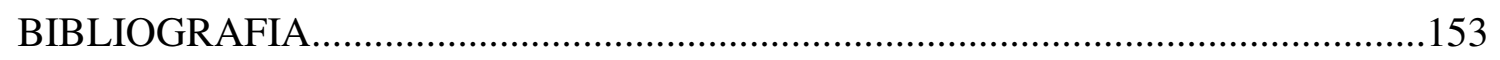




\section{RESUMO}

O presente trabalho tem por objetivo traçar os principais contornos do instituto do benefício particular, positivado na legislação brasileira por meio do artigo $115, \S 1^{\circ}$, da Lei n. 6.404/76, diferenciando-o do instituto relativo ao interesse conflitante nas sociedades, insculpido no mesmo dispositivo supra citado. A partir da análise do Direito Comparado, constatou-se que o benefício particular, tal como o conhecemos hoje no Brasil, tem origem na legislação francesa, especificamente nas Leis de 17 de julho de 1956 e 24 de julho de 1867. Os contornos de sua conceituação, portanto, estão intimamente ligados às razões de ordem histórica e teleológica que levaram o legislador estrangeiro a criá-lo, o qual visava, à época, afastar os abusos e inconveniências decorrentes da aprovação, em assembleia, de vantagens especiais e exclusivas pelo próprio sócio beneficiário dessas vantagens. Complementarmente, por meio da análise e interpretação sistemática da legislação societária brasileira e de outras fontes de direito disponibilizadas, como a doutrina e a jurisprudência, pôde-se definir algumas das características mais marcantes do instituto, das quais se pode destacar a licitude, a gratuidade e o caráter social das vantagens a ele associadas, garantindo ao beneficiado acesso aos fundos sociais. Em paralelo, para fins de mera comparação com o instituto do benefício particular, foram abordados alguns aspectos relativos ao instituto do conflito de interesses, reafirmando conceitos doutrinários já sedimentados acerca do alcance do interesse social e procurando, a partir da análise da legislação brasileira e comparada, fixar alguns elementos intrínsecos a esse instituto, tal como a ilicitude e o caráter extrassocial da vantagem visada pelo acionista conflitado. Comparando as características do benefício particular e do conflito de interesses, pode-se concluir que, apesar da aparente semelhança que carregam, tratam-se de institutos distintos, que regulam situações diversas, não podendo ser confundidos ou tomados um pelo outro, sendo possível, de fato, se estabelecer um critério relativamente seguro para distinguilos entre si, conferindo uma maior segurança jurídica aos aplicadores do direito, evitando-se, assim, algumas interpretações equivocadas acerca dos institutos, tais como aqueles constantes nos posicionamentos da Comissão de Valores Mobiliários analisados ao final desse trabalho. 
PALAVRAS-CHAVES: Sociedade Anônima. Ações. Acionistas. Assembleia. Voto. Interesse Social. Benefício Particular. Conflito de Interesses. Impedimento de Voto. Parecer de Orientação CVM n. 34. Voto Abusivo. Invalidade de Deliberações. Incorporação de Ações. Transações com Partes Relacionadas. Comissão de Valores Mobiliários. 


\begin{abstract}
The current paper has the sole purpose of designing the main lines of the private benefits regulation, reaffirmed by means of Act $115, \S 1$ st, in the Brazilian law number 6.404/76, distinguishing it from institutions that relate to conflicting partnership interests, comprehended by the same aforementioned Act. From assessing the Paired Law regulation, it has been understood that the private benefits, such as it is currently recognized in Brazil, is based on the French legislation, more specifically on the July 17, 1956 and July 24, 1867 Acts. Therefore, the contours of its conceptualism are intimately connected to historic and teleological reasoning that took the foreign regulator to create it and which aimed, at that time, to keep away abuse and inconveniences resulting from the approval, in an shareholders meeting, of special and exclusive advantages by their own beneficiary parties. In addition, by means of systematically assessing and interpreting the Brazilian Corporate Law and other Law resources made available, such as the Law doctrine and jurisprudence, it was possible to determine some of the most outstanding characteristics of such an institute, among which the lawfulness, gratuity and social character of the advantages associated with it can be highlighted, thus assuring the access of the beneficiary party to social funds. In parallel, by means of solely comparing the private benefits regulation, some aspects regarding the conflict of interests were also assessed, reaffirming doctrine concepts about the reach of social interests that are already established and trying to determine, by means of analyzing the Brazilian Corporate Law and Paired Law, some of the elements that are inherent to that establishment, such as its wrongfulness and the extrasocial character of the advantage pledged by the conflicting party. By pairing the characteristics of private benefits and the conflict of interests, it is concluded that, despite their apparent similarities, those are distinct institutes that regulate diverse situations, which cannot be confused or taken by one another and, in fact, it is possible to establish a relatively safe criteria to differentiate both, thus providing greater judicial accuracy to Law enforcers, and this way avoiding misinterpretation of regulation, such as those that are common to the positioning of the Brazilian Securities and Exchange Commission that are analyzed in the end of this paper.
\end{abstract}


KEY-WORDS: Corporation. Shares. Shareholders. Shareholders Meeting. Vote. Social Interest. Private Benefits. Conflict of Interests. Impediment of Vote. CVM Law Guidance \# 34. Abusive Vote. Void Deliberation.. Transactions with Related Parties. Brazilian Securities and Exchange Commission. 



\section{I - INTRODUÇÃO}

O trabalho desenvolvido no âmbito da presente dissertação de mestrado tratará do instituto do benefício particular nas sociedades anônimas, o qual enseja o impedimento do exercício do direito de voto do acionista particularmente beneficiado.

O impedimento do exercício do direito de voto do acionista em assembléias gerais de sociedades anônimas, em razão de seu benefício particular, está previsto no ordenamento jurídico pátrio por meio do artigo $115, \S 1^{\circ}$, da Lei $n^{\circ} 6.404$, de 15 de dezembro de 1976 (Lei das Sociedades por Ações).

A legislação em comento, além de definir especificamente duas situações em que ocorrerá o impedimento do exercício do direito de voto do acionista (aprovação de laudo de avaliação em que concorrer para a formação do capital social e aprovação de suas contas como administrador), ainda o admite, genericamente, em duas outras circunstâncias principais: no caso da concretização do conflito de interesses e/ou da configuração do benefício particular.

A principal finalidade do supra citado comando legal é proteger a companhia contra decisões impulsionadas por interesses exclusivamente particulares, alguns não condizentes com os interesses sociais (no caso do conflito de interesses), bem como contra deliberações cujos efeitos se reverterão em proveito exclusivo de apenas determinados acionistas, alterando os padrões de igualdade entre detentores de ações da mesma classe e espécie (na hipótese do benefício particular).

$\mathrm{O}$ instituto do benefício particular tem origem no direito francês, aparecendo sob a expressão "vantagens estipuladas nos estatutos ou contrato social", conforme Lei Francesa de 24 de julho de 1867, célebre carta legal que afastou a tutela administrativa do Poder Público às sociedades anônimas, instituindo o regime das liberdades regulamentadas ${ }^{1}$. A referida Lei

\footnotetext{
${ }^{1}$ FRANÇA, Erasmo Valladão e Novaes. Temas de Direito Societário, Falimentar e Teoria da Empresa. São Paulo: Malheiros, 2009, p. 570.
} 
Francesa continha previsão expressa no sentido de que "os acionistas que fizeram o aporte ou estipularam as vantagens particulares que serão submetidas à assembléia não participam da deliberação ${ }^{2} ”$.

No Brasil, termo semelhante constou na Lei $\mathrm{n}^{\circ} 3.150$ de 1882 , que, da mesma forma que a Lei Francesa supra citada, extinguiu o regime das autorizações para a constituição das sociedades anônimas ${ }^{3}$.

Como será demonstrado no decorrer do presente trabalho, as bases conceituais do instituto do benefício particular foram assentadas pela doutrina nacional e estrangeira, sobretudo francesa, podendo ser consignados alguns pontos sobre os quais não recaem maiores discussões.

Dentre eles, o entendimento de que o benefício particular ocorre em situações nas quais determinado acionista ou grupo de acionistas é contemplado com vantagens particulares, exclusivas, independentemente se o acionista particularmente interessado tenha o intento de prejudicar a companhia ou os demais acionistas, bastando que lhe sejam concedidos proveitos exclusivos, que não serão aproveitados por qualquer outro acionista ${ }^{4}$.

Nessa linha, o benefício particular passa a estar atrelado a situações que provocam um desequilíbrio da igualdade entre acionistas de uma sociedade anônima ${ }^{5}$. Vale dizer, toda vez que é concedido a determinado acionista, a título gratuito, algo que não o será aos demais

\footnotetext{
${ }^{2}$ Literalmente: Les associes qui on fait l'apport ou stipulé dês avantages particuliers sumis à l'appreciation de l'assemblée n'ont pás voiz delibérative (www.edbm.gov.mg/system/application/resources/docs/societe_commerciales_loi_24071867.doc).

${ }^{3}$ FRANÇA, Erasmo Valladão e Novaes. Conflito de Interesses nas Assembleias de S.A. São Paulo: Malheiros, 1993, p. 69

4 Parecer de Orientação CVM no 34, de 18 de agosto de 2006: "A constatação do impedimento de voto não envolve um julgamento sobre a licitude da deliberação a ser tomada. $O$ acionista potencialmente favorecido estará impedido de votar mesmo que se trate, como se espera, de deliberar sobre benefícios perfeitamente lícitos, e que possam coincidir com o interesse da companhia”.

${ }^{5}$ SCHIMIDT, D. Le Conflits d'Intérêts dans la Société Anonymme. Paris: Joly, 1999, p. 52-53.
} 
e que possa ocasionar, sobretudo, um desequilíbrio ao acesso aos fundos sociais, se estará diante de uma situação de benefício particular.

Até por essa razão, a vedação ao exercício do voto por acionista beneficiado particularmente em determinado conclave societário encontrou sua ratio no preceito "Nemo Iudex In Causa Própria”, segundo o qual ninguém pode julgar em causa própria, sendo, ao mesmo tempo, juiz e parte de seus próprios atos.

No entanto, ainda resta muita controvérsia quando o assunto é o benefício particular, sendo que alguns pontos são bastante polêmicos, merecendo atenção especial da doutrina, para que não se corra o risco de mal interpretação e/ou aplicação do referido instituto, gerando indesejável insegurança jurídica. Como exemplo de matérias que merecem ser superadas, podem ser citadas:

1) Delineamento da conceituação e definição da abrangência de aplicação do benefício particular

a) Deve ser entendido como benefício particular apenas a vantagem lícita ou também a ilícita eventualmente obtida pelo acionista?

b) O benefício particular contempla apenas as vantagens pecuniárias auferidas pelo acionista ou toda e qualquer situação que lhe promova uma vantagem exclusiva?

c) O benefício particular é toda e qualquer vantagem obtida pelo acionista ou somente aquelas em que puder auferir enquanto sócio da companhia?

2) Diferenciação do benefício particular em relação ao conflito de interesses

a) Quais as principais semelhanças e diferenças entre o benefício particular e o conflito de interesses?

b) O conflito de interesse poderia co-existir com o benefício particular em determinadas situações?

c) O conceito do benefício particular está, de alguma forma, contido no conceito de conflito de interesses? 
d) O controle do benefício particular se dá ex ante, ou seja, trata-se de genuína hipótese do que a doutrina italiana denominou divieto de voto, ou ex post da deliberação assemblear?

3) Consequências da violação à regra legal

a) Qual a consequência da violação da regra do artigo $115, \S 1^{\circ}$, da Lei das Sociedades por Ações, na hipótese do benefício particular?

No campo prático, a aplicação do instituto do benefício particular ganha destaque nas operações envolvendo reorganizações societárias, eventos cada vez mais correntes em função da crescente pujança da economia nacional e a busca pela consolidação dos mercados pelas companhias. Operações em que a discussão do benefício particular ganhou cena foram as reorganizações societárias do Grupo AMBEV (2004), FOSFERTIL (2007), MG POLIÉSTER (2007), DURATEX-SATIPEL (2009), SADIA (2009), dentre outras, dando ensejo, inclusive, à publicação pela Comissão de Valores Mobiliários do Parecer de Orientação n. 34.

Vale também destacar a discussão da existência do benefício particular em transações com partes relacionadas, ganhando vulto os casos TELE SUL PARTICIPAÇÕES (2001), PREVI-SISTEL (2002) e TRACTEBEL (2009).

Entretanto, a doutrina nacional é carente de uma monografia que trate do tema em estudo de forma sistemática e específica, destacando suas origens históricas, aclarando seus conceitos e definido o alcance e abrangência da aplicação prática do instituto do benefício particular.

Nesse sentido, é de suma importância que haja um estudo científico exclusivo do referido instituto, ainda mais no momento atual, em que sua utilidade se faz cada vez mais crescente no âmbito das companhias. 
De fato, a globalização dos mercados, facilitando o fluxo de negócios e informações, tem propiciado o ingresso de investidores estrangeiros no mercado de capitais brasileiro, contribuindo para seu crescimento ${ }^{6}$, o qual passou a contar também com grandes investidores institucionais nacionais, como os fundos de pensão e de investimento em geral ${ }^{7}$.

Tais circunstâncias têm impulsionado uma verdadeira mudança cultural e institucional nas companhias brasileiras, que, impreterivelmente, necessitam se tornar mais receptivas ao crescente ativismo acionário, ao maior interesse dos acionistas minoritários em participar dos conclaves societários e, por fim, à valorização das boas práticas de governança corporativa $^{8}$.

Assim, é evidente que o direito de voto, bem como suas condições, restrições ou impedimentos, começam a ganhar corpo, valendo lembrar, nesse sentido, que a própria CVM vem cada vez mais estimulando a presença de acionistas em assembleias gerais ${ }^{9}$, o que torna inevitável o aumento das discussões atinentes ao exercício de voto.

Neste contexto, é imprescindível que os contornos do instituto do benefício particular, o qual, como se disse, enseja o impedimento do exercício de voto do acionista, esteja bem definido e assentado, para conceder aos conclaves societários maior segurança jurídica.

Afinal, a pujança de um mercado de capitais, além dos aspectos de cunho econômico-financeiro, está estritamente relacionada com a segurança jurídica concernente aos investimentos realizados ${ }^{10}$.

\footnotetext{
${ }^{6}$ BETARELLO, F.C. Governança Corporativa: Fundamentos Jurídicos e Regulação. São Paulo: Quartier Latin, 2009, p.70-71.

${ }^{7}$ Ibdem, idem, p. 78-79.

${ }^{8}$ LODI, J.B. Governança Corporativa: O Governo da Empresa e o Conselho de Administração. Rio de Janeiro: Campus, 2000, p. 16-17.

${ }^{9}$ Exemplo disso foi a publicação da Instrução CVM n. 481, de 17 de dezembro de 2009 que, ao regulamentar a utilização de pedidos públicos de procuração, teve por intuito incentivar a participação dos acionistas no âmbito do processo decisório da companhia.

${ }^{10}$ LODI, J.B. Op.cit, p. 16-17.
} 
Vale dizer, dificilmente um mercado de capitais poderá alçar vôos mais altos se os procedimentos e práticas adotados não forem realizados em conformidade com as normas vigentes. Por mais que uma economia demonstre solidez, nenhum investidor se sentirá confortável em ambiente que não conceda um mínimo de segurança para seu investimento, ou em outras palavras, cujo regramento normativo referente às práticas e operações de mercado não esteja devidamente compreendido e interpretado.

Portanto, o tema em questão tem por intuito contribuir para a mais sadia discussão acerca da interpretação de nossa legislação societária relativa ao instituto do benefício particular nas sociedades anônimas, na expectativa de contribuir para o aprimoramento do tema objeto do trabalho, auxiliando no desenvolvimento e no crescimento do mercado de capitais brasileiro e, sobretudo, de toda a economia nacional. 


\section{I - O BENEFÍCIO PARTICULAR: ORIGENS, CONCEITUAÇÃO, EFEITOS E CONSEQUENCIAS}

O artigo 115, § $1^{\circ}$, da Lei $n^{\circ}$ 6.404, de dezembro de 1976 (“LSA”) dispõe que o acionista não poderá votar nas deliberações da assembléia-geral relativas ao laudo de avaliação de bens com que concorrer para a formação do capital social e à aprovação de suas contas como administrador, nem em quaisquer outras que puderem beneficiá-lo de modo particular, ou em que tiver interesse conflitante com o da companhia.

A norma supra citada é expressa ao prescrever que o acionista não poderá votar nas deliberações que puderem beneficia-lo de modo particular. No entanto, no que consiste o benefício particular?

Semanticamente, a palavra "benefício" significa serviço ou bem que se faz gratuitamente; favor, graça; vantagem, proveito. Por outro lado, o termo "particular" diz respeito a algo relativo a apenas uma ou algumas pessoas, algo privativo ${ }^{11}$.

Deste modo, a partir da interpretação semântica do instituto, o benefício particular poderia ser conceituado como a vantagem concedida a título gratuito a determinada pessoa ou grupo de pessoas.

No entanto, a boa hermenêutica não se restringe ao aspecto semântico do texto normativo, devendo o operador do direito se valer de outros critérios de interpretação, tal como a interpretação histórico-teleológica da norma ${ }^{12}$.

\footnotetext{
${ }^{11}$ Dicionário Aurélio da Língua Portuguesa, $4^{\circ}$ ed. Rio de Janeiro: Nova Fronteira, 2001.

${ }^{12}$ No que se refere às técnicas de exegese, ANGÉL afirma que: "A partir del supuesto de que el legislador es omnisapiente, la exégesis considera su obra perfecta, y en consecuencia, lo que este diga, dicho está; y lo que lo calle, callado está. Tanto lo afirmado como lo omitido constituyen clara expresión de la vontade del legislador. Esta voluntad se puede descobrir por tres caminos distintos, así: a) En primer lugar, a través del significado de los terminos en los cuales está redactado ela mandacto; es el análisis semantico; b) En segundo lugar, cuando las normas tienem vacíos, es necesario llenarlos utilizando de los principios de la logica [...]; c) En tercer lugar, también se puede descobrir la voluntad del legislador a través del analisis de los documientos producidos
} 
Assim, para uma mais precisa conceituação da expressão "benefício particular", útil seria realizar uma breve incursão às origens do instituto, com vistas a se buscar a finalidade buscada pelo legislador da época.

\section{$\underline{1.1 \text { - Origens do Instituto do Benefício Particular }}$}

O instituto do benefício particular, tal como se conhece hoje no Brasil, tem sua fonte no Direito Continental Europeu, sobretudo França e Alemanha, cujas legislações acabaram por conceder as diretrizes da construção de tal instituto no Brasil.

\section{$\underline{1.1 .1-\text { As origens do Benefício Particular na França }}$}

As origens do instituto do benefício particular remontam ao direito francês. RIVIÈRE, jurista francês do século XIX, afirma que o termo "avantage particulier" apareceu pela primeira vez na Lei de 17 de julho de 1856, aplicada às sociedades comanditas por ações $^{13}$.

O supra citado autor relata alguns problemas existentes no âmbito dos procedimentos de constituição das sociedades comanditas por ações, ensejando abusos por parte de acionistas no momento de atribuição de valor de seus aportes ou estipulação de vantagens pessoais. A exemplo, aponta que nas sociedades comanditas por ações, a formalização da ata de constituição da sociedade prescindia da assinatura de todos os acionistas, o que ensejava exageros na fixação de valores dos bens e vantagens aos

durante el proceso de formulation de la norma, como la exposicion de motivos, los debates en el Congreso, etc." No mais, versando sobre outras técnicas de interpretação, consigna que "Por ultimo, se puede interpretar la norma teniendo en cuenta las condiciones empiricas concretas que le van a permitir alcanzar el fin a que se pretende com ella" (ANGÉL, J.G.. Hermenéutica Juridica: Homenaje al Maestro Darío Echandía. Santa Fé de Bogotá: Rosaritas, 1997).

${ }^{13}$ Nesse sentido: "Les lois antérieures y avaient déjà pourvu; l'art.4 de la loi du 1867 en reproduit les sages prescription. La plupart des disposition de cet article sont empruntées à l'art.5 de la loi de 23 maio 1863, sur les sociétés à responsabilité limitée, qui avait elle-même reproduit plusieurs dispositions de l'art.4 de la loi du 17 juillet 1856, sur les société en commandite par actions" (Commentaires sur la Loi 24 de juillet de 1867 sur les Sociétes. Paris: A.Marescq Ainé Librarie Editeur, 1868, p. 84). 
fundadores, dada a ausência de controle e verificação por parte da integralidade do corpo social $^{14}$.

Com vistas então a regular a sistemática de aportes e concessão de vantagens especiais, instituiu-se um mecanismo com a finalidade de mitigar ou mesmo afastar a prática de tais abusos, mecanismo que foi reproduzido pela Lei Francesa de 24 de julho de 1867, mas especificamente pelo seu artigo $4^{\circ}$, que assim dispunha ${ }^{15}{ }^{16}$ :

“Art. 4. - Lorsqu’un associé fait un apport qui ne consiste pas en numéraire, ou stipule à son profit des avantages particuliers, la première assemblée générale fait apprécier la valeur de l'apport ou la cause des avantages stipulés.

La société n'est définitivement constituée qu'après l'approbation de l'apport ou des avantages, donnée par une autre assemblée générale, après une nouvelle convocation.

La seconde assemblée générale ne pourra statuer sur l'approbation de l'apport ou des avantages qu'après un rapport qui sera imprimé et tenu à la disposition des actionnaires, cinq jours au moins avant la réunion de cette assemblée.

Les délibérations sont prises par la majorité des actionnaires présents. Cette majorité doit comprendre le quart des actionnaires et représenter le quart du capital social en numéraire.

Les associés qui ont fait l'apport ou stipulé des avantages particuliers soumis à l'appréciation de l'assemblée n'ont pas voix délibérative. A défaut d'approbation, la société reste sans effet à l'égard de toutes les parties."17 18

\footnotetext{
${ }^{14}$ Segundo o autor, "Dans la commandite par actions l'acte de société est rédigé en l'absence des actionnaires; il n'y a point de controle, a point de vérification. Il n'en existe pas davantage quand les actionnaires viennent souscrire; c'est ce qui était autrefois la cause de tant d'abus et d'exagération dans la valeur des apports" (RIVIÈRE, H. Commentaires sur la Loi 24 de juillet de 1867 sur las Sociétes. Paris: A.Marescq Ainé Librarie Editeur, 1868, p 24.)

15 Ibdem, idem, p. 84..

16 O dispositivo ainda vedava o voto para aprovação do valor do aporte ou das vantagens particulares para cônjuges ou parentes até quarto grau do acionista, bem como qualquer pessoa com qualquer ligação de ordem econômica com o acionista.

17 Livre tradução: Art. $4^{\circ}$. Quando um sócio faz um aporte que não consiste em um numerário ou estipula para seu proveito vantagens particulares, a primeira assembléia geral determina o valor do aporte ou a causa das vantagens particulares. A sociedade não é definitivamente constituída senão após a aprovação do aporte ou das vantagens, dada por uma outra assembléia geral após nova convocação. A segunda assembléia não poderá estatuir sobre a aprovação do aporte ou das vantagens senão após um relatório que será impresso e colocado à disposição dos acionistas no mínimo 5 (cinco) dias da reunião desta assembléia. As deliberações são aprovadas pela maioria dos acionistas presentes. Tal maioria deve obrigatoriamente compreender um quarto dos acionistas e representar um quarto do capital social em dinheiro. $\mathrm{O}$ acionista que faz o aporte ou é beneficiário das vantagens estipuladas que serão submetidas à assembléia não participam da deliberação" .
} 
A Lei Francesa de 24 de julho de 1867, também conhecida como "Lei das Sociedades", trazendo regras aplicáveis às sociedades comanditas por ações, às sociedades anônimas e às sociedades cooperativas, foi instituída em época em que a civilização ocidental experimentava significativo progresso econômico-industrial.

Deste modo, a referida Lei teve por objetivo contribuir para a manutenção e desenvolvimento de tal progresso, por meio da fixação de normas societárias tendentes a abolir barreiras que dificultavam o crescimento das sociedades ${ }^{19}$.

No tocante às sociedades anônimas, por exemplo, a Lei Francesa de 1867 extinguiu o regime das autorizações governamentais para constituição de tais sociedades, instituído pelo Code de Commerce, no início do século XIX, mais especificamente pelo seu artigo 37, o qual preconizava que "La société anonyme ne peut exister qu'avec l'autorization du governement et avec son approbation pour l'acte qui la constitue".

Até por ser trazer um mecanismo importado das normas atinentes às sociedades comanditas por ações, o supra citado artigo $4^{\circ}$ da Lei Francesa de 1867 encontrava-se na primeira seção da referida Lei, dedicada justamente às sociedades comanditas por ações.

Tal como a lei anterior, a sistemática prevista no artigo $4^{\circ}$ da Lei Francesa de 24 de julho de 1867 tinha por intuito estabelecer os procedimentos necessários para a constituição de uma sociedade cuja integralização de suas ações se desse por meio de bens e/ou direitos que

\footnotetext{
${ }^{18} \mathrm{O}$ termo "avantage particulier" voltava a aparecer no artigo 8 da mesma Lei Francesa, no qual se impunha a responsabilidade a acionistas e administradores que realizarem aportes ou estipulassem vantagens particulares sem respeitar o procedimento previsto no supra citado artigo 4.

${ }^{19}$ Nesse sentido, discurso proferido pelo Imperador Napoleão III durante a abertura da sessão legislativa de 1865: "De nouveaux projets auront pour but de laisser une liberté plus grande aux associations commerciales et de dégager la responsabilité toujours illusoire de 1 administration. J'ai tenu à détruire tous les obstacles qui s'opposaient à la création des sociétés destinées à améliorer la condition des classes ouvrières En permettant l' établissement de ces sociétés sans abandonner les garanties de la sécurité publique nous faciliterons une utile expérience" (Rivière, H. Commentaires sur la Loi 24 de juillet de 1867 sur las Sociétes. Paris: A.Marescq Ainé Librarie Editeur, 1868, p. 2).
} 
não fosse dinheiro e/ou se fosse instituído, quando de sua constituição, qualquer vantagem particular em prol de determinado acionista.

Analisando-se o texto legal, constata-se que tal mecanismo de aprovação da instituição da vantagem particular tinha por intuito conceder aos acionistas o máximo de informações possíveis para que pudessem analisar as condições e circunstâncias em que a tal vantagem estava sendo estabelecida e com isso decidir, em assembléia geral, se deveria ou não ser aprovada. Sem tal aprovação, a sociedade não seria sequer constituída.

A sistemática consistia em proceder à análise e aprovação das vantagens particulares estipuladas em duas etapas, por meio da deliberação de duas assembléias gerais.

A primeira assembléia geral determinava a causa das vantagens particulares. A sociedade não seria definitivamente constituída senão após a aprovação de tais vantagens, dada por uma outra assembléia geral após nova convocação. Essa segunda assembléia não poderia deliberar sobre a aprovação das vantagens senão após um relatório que deveria ser impresso e colocado à disposição dos acionistas com no mínimo 5 (cinco) dias de antecedência da realização dessa assembléia, sendo que o acionista que fosse beneficiário das vantagens estipuladas não participaria da deliberação.

O procedimento acima também foi estendido às sociedades anônimas, por força do artigo 24 do mesmo diploma legal ${ }^{20}$, que, como acima se afirmou, passava por um momento de transição de regime, em função da extinção da necessidade de autorização estatal para sua constituição.

Como afirma RIVIÈRE ${ }^{21}$, por meio do regime das autorizações, o Estado se incumbia de verificar o estatuto social submetido à autorização, de modo a garantir que não houvesse qualquer estipulação contrária à lei ou que pudesse prejudicar algum acionista ou

\footnotetext{
20 “Art. 24. - Les dispositions des articles 1, 2, 3 et 4 de la présente loi sont applicables aux sociétés anonymes".

${ }^{21}$ RIVIÈRE, H. Op.cit. p. 11.
} 
terceiros. Assim, para compensar a ausência da tutela do Estado, foi necessária a instituição de normas que regrassem com maior eficácia a relação entre sociedades, acionistas e terceiros.

Por essa razão, foi considerado adequado estender às sociedades anônimas as regras referentes à aprovação dos aportes ou estipulação das vantagens particulares, aplicáveis, originalmente, às sociedades comanditas por ações.

Assim, criado para mitigar um problema existente no âmbito das sociedades comanditas por ações, o instituto do benefício particular tornou-se também aplicável às sociedades anônimas por meio da Lei de 24 de julho de 1867, consolidando-se, a partir de então, no ordenamento jurídico francês.

De fato, a expressão "avantages particulier" tornou a aparecer na Lei Francesa de 24 de julho de 1966, praticamente reproduzindo, em essência, as disposições da lei anterior, porém, estendendo sua aplicação não apenas aos acionistas, mas também a terceiros. Vale dizer, o procedimento de verificação legal passou a valer para a estipulação da vantagem particular a qualquer pessoa, acionista ou não ${ }^{22}$.

\footnotetext{
${ }^{22}$ Art. 80. En cas d'apports en nature comme au cas de stipulation d'avantages particuliers au profit de personnes associées ou non, un ou plusieurs commissaires aux apports sont désignés par décision de justice, à la demande des fondateurs ou de l'un d'entre eux. Ils sont soumis aux incompatibilités prévues à l'article 220.

Ces commissaires apprécient, sous leur responsabilité, la valeur des apports en nature et les avantages particuliers. Le rapport déposé au greffe, avec le projet de statuts, est tenu à la disposition des souscripteurs, dans les conditions déterminées par décret. L'assemblée générale constitutive statue sur l'évaluation des apports en nature et l'octroi d'avantages particuliers. Elle ne peut les réduire qu'à l'unanimité de tous les souscripteurs. A défaut d'approbation expresse des apporteurs et des bénéficiaires d'avantages particuliers, mentionnée au procèsverbal, la société n'est pas constituée.

Art. 82. Chaque souscripteur dispose d'un nombre de voix égal à celui des actions qu'il a souscrites, sans que ce nombre puisse excéder dix. Le mandataire d'un souscripteur dispose des voix de son mandant dans les mêmes conditions et la même limite. Lorsque l'assemblée délibère sur l'approbation d'un apport en nature ou l'octroi d'un avantage particulier, les actions de l'apporteur ou du bénéficiaire ne sont pas prises en compte pour le calcul de la majorité. L'apporteur ou le bénéficiaire n'a voix délibérative, ni pour lui-même, ni comme mandataire.

[Livre Tradução: Art. 80. No caso das contribuições em espécie como no caso de estipulação de vantagens particulares em benefício de sócios ou não, um ou mais comissários são designados por decisão judicial, a pedido dos fundadores ou por um dentre eles, os quais serão submetidos às incompatibilidades previstas no artigo 220 . Os comissários apreciarão, sob sua responsabilidade, o valor das contribuições em espécie e das vantagens particulares. O relatório apresentado ao Registro, bem como o projeto do estatuto, serão postos à disposição dos subscritores, conforme condições determinadas por decreto. A assembleia geral de constituição decide sobre a avaliação das contribuições em espécie e sobre a concessão de vantagens particulares, os quais podem ser reduzidos pela unanimidade de todos os subscritores. Na ausência de aprovação expressa daqueles que realizaram
} 
Ao que tudo indica, essa extensão dos destinatários do benefício pretendeu alcançar as vantagens concedidas a administradores, principalmente àqueles que exerceram longos anos de serviço à companhia, muito comum no meio societário ${ }^{23}$.

Tal extensão foi mantida pelo Code de Commerce, o qual faz menção ao instituto do benefício particular em quatro hipóteses específicas: (i) constituição da sociedade (artigo 225-8); (ii) aumento de capital (artigo 225-147); (iii) fusão (artigo 236-10); (iv) transformação de uma sociedade em sociedade anônima ${ }^{24}$. Em todas as hipóteses, o acionista particularmente

a contribuição e dos beneficiários das vantagens particulares, conforme consignado em ata, a sociedade não será constituída.

Art. 82. Cada subscritor tem um número de votos igual ao número de suas ações subscritas, número esse que não excederá a dez. O mandatário de um subscritor possui o direito de voto de seu mandante nas mesmas condições e limites. Quando a assembleia deliberar sobre a aprovação de uma contribuição em espécie ou a concessão de uma vantagem particular, as ações daqueles que fez a contribuição ou daquele que foi beneficiado com a vantagem não são levadas em conta para o cálculo da maioria. Aquele que faz a contribuição em espécie ou o beneficiário de uma vantagem particular não vota, nem por si, nem como mandatário.]

${ }^{23}$ COSIAN, M. et alli. Droit des Sociétés, 19 ed. Paris: LexisNexis, 2006, item 467.

24 225-8. En cas d'apports en nature comme au cas de stipulation d'avantages particuliers au profit de personnes associées ou non, un ou plusieurs commissaires aux apports sont désignés par décision de justice, à la demande des fondateurs ou de l'un d'entre eux. Ils sont soumis aux incompatibilités prévues à l'article L. 822-11. Les commissaires apprécient, sous leur responsabilité, la valeur des apports en nature et les avantages particuliers. Le rapport déposé au greffe, avec le projet de statuts, est tenu à la disposition des souscripteurs, dans les conditions déterminées par décret en Conseil d'Etat. L'assemblée générale constitutive statue sur l'évaluation des apports en nature et l'octroi d'avantages particuliers. Elle ne peut les réduire qu'à l'unanimité de tous les souscripteurs. A défaut d'approbation expresse des apporteurs et des bénéficiaires d'avantages particuliers, mentionnée au procèsverbal, la société n'est pas constituée.

225-10. Lorsque l'assemblée délibère sur l'approbation d'un apport en nature ou l'octroi d'un avantage particulier, les actions de l'apporteur ou du bénéficiaire ne sont pas prises en compte pour le calcul de la majorité. L'apporteur ou le bénéficiaire n'a voix délibérative ni pour lui-même ni comme mandataire.

225-147. En cas d'apports en nature ou de stipulation d'avantages particuliers, un ou plusieurs commissaires aux apports sont désignés par décision de justice. Ils sont soumis aux incompatibilités prévues à l'article L. 822-11. Ces commissaires apprécient, sous leur responsabilité, la valeur des apports en nature et les avantages particuliers. Un décret en Conseil d'Etat fixe les mentions principales de leur rapport, le délai dans lequel il doit être remis et les conditions dans lesquelles il est mis à la disposition des actionnaires. Les dispositions de l'article L. 225-10 sont applicables à l'assemblée générale extraordinaire. Si l'assemblée approuve l'évaluation des apports et l'octroi d'avantages particuliers, elle constate la réalisation de l'augmentation du capital.

Si l'assemblée réduit l'évaluation des apports ainsi que la rémunération d'avantages particuliers, l'approbation expresse des modifications par les apporteurs, les bénéficiaires ou leurs mandataires dûment autorisés à cet effet, est requise.A défaut, l'augmentation du capital n'est pas réalisée. 
interessado não pode tomar parte na deliberação que tiver por objeto aprovar o benefício particular.

\subsection{2- As origens do Benefício Particular na Alemanha}

Apesar de o instituto do benefício particular não ser aplicado atualmente na Alemanha tal como o conhecemos hoje no Brasil, é importante demonstrar como a legislação alemã vem tratando tal tema.

Sob influência da Lei Francesa de 17 de julho de 1856, o termo vantagens especiais (Sondervorteile) constou no Código Comercial Geral Alemão de 1861 (Allgemeine Deutsche Handelsgesetzbuch - ADHGB), ao tratar, como a supra citada Lei Francesa, das sociedades comanditas por ações.

$\mathrm{O}$ artigo 180 do $\mathrm{ADGHG}^{25}$, de modo muito semelhante à legislação francesa, prescreve que quando um investidor integralizar suas participações societárias com outros

236-10 III. Lorsque l'opération de fusion comporte des apports en nature ou des avantages particuliers, le commissaire à la fusion ou, s'il n'en a pas été désigné en application du II, un commissaire aux apports désigné dans les conditions prévues à l'article L. 225-8 établit le rapport prévu à l'article L. 225-147.

224-3. Lorsqu'une société de quelque forme que ce soit qui n'a pas de commissaire aux comptes se transforme en société par actions, un ou plusieurs commissaires à la transformation, chargés d'apprécier sous leur responsabilité la valeur des biens composant l'actif social et les avantages particuliers, sont désignés, sauf accord unanime des associés par décision de justice à la demande des dirigeants sociaux ou de l'un d'eux. Les commissaires à la transformation peuvent être chargés de l'établissement du rapport sur la situation de la société mentionné au troisième alinéa de l'article L. 223-43. Dans ce cas, il n'est rédigé qu'un seul rapport. Ces commissaires sont soumis aux incompatibilités prévues à l'article L. 225-224. Le commissaire aux comptes de la société peut être nommé commissaire à la transformation. Le rapport est tenu à la disposition des associés.

Les associés statuent sur l'évaluation des biens et l'octroi des avantages particuliers. Ils ne peuvent les réduire qu'à l'unanimité. A défaut d'approbation expresse des associés, mentionnée au procès-verbal, la transformation est nulle.

25 Artikel 180.Wenn ein Gesellschafter eine Einlage macht, welche nicht in baarem Gelde besteht, oder wenn er sich $\mathrm{zu}$ seinen Gunsten besondere Vortheile ausbedingt, so muß in einer Generalversammlung der Kommanditisten die Abschätzung und Prüfung der Zulässigkeit angeordnet und in einer späteren Generalversammlung die Genehmigung durch Beschluß erfolgt sein. Der Beschluß wird nach der Mehrheit der in der Versammlung anwesenden oder durch Vollmacht vertretenen Kommanditisten gefaßt; jedoch muß diese Mehrheit mindestens ein Viertheil der sämmtlichen Kommanditisten begreifen und der Betrag ihrer Antheile zusammen mindestens ein Viertheil des Gesammtkapitals der Kommanditisten darstellen. Der Gesellschafter, 
recursos que não dinheiro ou se estipular para si vantagens especiais, uma reunião geral de sócios deverá avaliar tais bens aportados ou tais vantagens estabelecidas, de modo que se tenha condições de submeter a questão à aprovação da assembléia geral, a qual se fará pela maioria dos acionistas presentes ou representados por procuração.

Ainda de acordo com o ADGHG, é condição para a aprovação da fixação das aludidas vantagens que essa maioria compreenda, no mínimo, um quarto dos sócios comanditários e represente, pelo menos, um quarto do capital social. Por fim, o dispositivo em comento ainda prescrevia que o sócio que tivesse realizado tal aporte ou que fosse beneficiário da vantagem especial em questão não poderia exercer seu direito de voto no âmbito da aludida deliberação.

O conceito das Sondervorteile também esteve presente no Código Comercial Alemão de 1897, que entrou em vigor em $1^{\circ}$ de janeiro de 1900 (Handelsgesetzbuch - HGB). $\mathrm{O}$ artigo 186 do HGB, aplicado às sociedades anônimas, prescrevia que qualquer vantagem especial concedida a um determinado acionista deveria constar no estatuto da sociedade, juntamente com o nome do acionista beneficiado, sob pena de não se tornar válida a estipulação ${ }^{26}$.

Ademais, o artigo 196 do HGB previa que na hipótese de os fundadores da sociedade não subscreverem todo o seu capital, seria convocada uma assembléia geral com a participação dos demais acionistas, com vista a deliberar sobre a constituição da companhia, sendo que, em tal hipótese, a aprovação das matérias se daria com, no mínimo, um quarto dos acionistas representando um quarto do capital social, sendo que, no que se refere à fixação das vantagens especiais, não poderia fazer cômputo dessa fração de votos a participação dos acionistas beneficiados com tais vantagens ${ }^{27}$.

welcher die Einlage macht oder sich besondere Vortheile ausbedingt, hat bei der Beschlußfassung kein Stimmrecht

${ }^{26}$ SCHUSTER, A.F. The German Commercial Code. London: Stevens \& Sons Ltd, 1911, p. 74.

${ }^{27}$ Ibdem, idem, p. 83. 
Entretanto, conforme ensina HERZFELDER ${ }^{28}$, com o advento da Lei Acionária Alemã de 1937 (Aktiengesetz), o tratamento do instituto do benefício particular foi alterado, deixando de existir na legislação alemã uma disposição que prescrevesse o impedimento de voto do acionista na hipótese de estipulação de vantagens particulares.

De fato, praticamente reproduzindo a disposição constante da Lei de 1937, a atual Aktiengesetz de 1965, prescreve, em seu artigo 26, que cada vantagem especial concedida a um determinado acionista deverá estar fixada no estatuto social, juntamente com o nome do acionista beneficiado, sob pena de se tornar inválida tal estipulação, nada mencionando sobre impedimento de voto do acionista particularmente beneficiado ${ }^{29}$.

De acordo com FRANÇA ${ }^{30}$, “a fixação no estatuto faz com que os acionistas sejam esclarecidos do benefício concedido a um deles, que rompe com o princípio da igualdade, mas também é feita sobretudo para que os credores sejam advertidos de que há uma vantagem particular, que às vezes é muito difícil de seu avaliada".

Assim, ao contrário do legislador francês, que previu o afastamento do exercício do direito de voto em diversas situações, tal como mencionado acima, o legislador alemão entendeu necessário somente dar a devida transparência a todos os stakeholders das vantagens especiais estipuladas, por meio de sua fixação no estatuto social, juntamente com o nome do acionista beneficiado.

\footnotetext{
${ }^{28}$ HERZFELDER, F. La protection de la société anonyme contre des abus de vote en cas de conflits d'intérêts en droit allemand. Tradução para o francês de Jean Escarra e Roger Houin. Revue Trimestrielle de Droit Commercial, tomo XXI, Paris: Librairie Sirey, 1968, p. 274.

${ }^{29} \$ 26$. Jeder einem einzelnen Aktionär oder einem Dritten eingeräumte besondere Vorteil muß in der Satzung unter Bezeichnung des Berechtigten festgesetzt werden. [...]Ohne diese Festsetzung sind die Verträge und die Rechtshandlungen zu ihrer Ausführung der Gesellschaft gegenüber unwirksam.

${ }^{30}$ FRANÇA, E.V.A e N. Ainda o conceito de benefício particular: anotações ao julgamento do processo CVM $n$. RJ 2009/5811. Revista de Direito Mercantil, Industrial, Econômico e Financeiro n. 149/150, ano XLVII (Nova Série), jan/dez 2008, p. 316.
} 


\subsection{3 - As origens do benefício particular no Brasil}

Entre as letras jurídicas pátrias, o conceito de benefício particular apareceu pela primeira vez com o advento da Lei $\mathrm{n}^{\circ} 3150$, de 4 de novembro de 1882, a qual introduziu efetivamente o modelo liberal no Brasil, ao libertar as sociedades anônimas da tutela administrativa do Poder Público ${ }^{31}$.

Observe-se, entretanto, que, sob a influência da Lei Francesa de 1867, o conceito apareceu sob a expressão "vantagens", sendo prescrito a proibição do exercício do voto do acionista em situações que lhe pudessem render tais "vantagens":

Art. 17, § 10: "Não podem votar nas assembléas geraes os administradores para approvarem seus balanços, contas e inventarios, os fiscaes os seus pareceres, e os accionistas a avaliação de seus quinhões, ou quaesquer vantagens estipuladas nos estatutos ou contrato social" (g.n.).

Assim, tal como a legislação francesa e alemã no final do século XIX, o legislador do Império impôs à obrigação ao acionista beneficiado de não tomar parte na deliberação que tiver por intuito aprovar a fixação de tais vantagens.

Entre os anos de 1882 e 1940, o instituto do benefício particular não sofreu qualquer alteração. O Decreto $n^{\circ} 434$ de 1891 apenas consolidou a legislação societária existente, materializando o instituto em seu artigo 142 , sendo de todo idêntico ao art. $17, \S 10$ da Lei n 3150.

\footnotetext{
31 Com efeito, de acordo com FRANCA, até a publicação do Decreto 575, de 10 de janeiro de 1849, a criação de sociedades anônimas no Brasil dependia exclusivamente de autorização do governo, tratando-se, pois, de verdadeiro privilégio. Assim, eram poucos aqueles que tinham condições de utilizar dessa espécie societária. $\mathrm{Na}$ medida em que a criação das sociedades anônimas passa a ser livre, tendeu-se a aumentar o número daqueles que delas passam a se utilizar. O legislador, já imaginando os efeitos que a liberdade de criação poderia implicar, adotou regra de caráter mais cogente, no intuito de disciplinar a relação societária nesse aspecto. Nada mais natural, então, que regras para disciplinar os interesses entre a sociedade e as partes envolvidas começassem a ser criadas (Conflito de Interesses nas Assembléias de S.A. São Paulo: Malheiros, 1993, p. 69).
} 
Posteriormente, com o advento do Decreto-Lei $n^{\circ} 2627$, de 26 de setembro de 1940, nota-se pequena alteração no texto da norma, tendo o legislador se referido expressamente ao "benefício particular", em seu artigo $82^{32}$.

Artigo 82: "O acionista não pode votar nas deliberações da assembléia geral relativas ao laudo de avaliação dos bens em que concorrer para a formação do capital social, nem nas que venham a beneficiá-lo de modo particular".

Como se percebe, o Decreto-Lei ${ }^{\circ} 2627$ torna o instituto mais abrangente. De fato, a partir de então, passa a ser proibido o voto do acionista interessado não apenas em relação às vantagens que poderiam ser estipuladas nos estatutos, mas em face de todo e qualquer benefício particular, inclusive aqueles não previstos nos estatutos.

FRANÇA atribui essa alteração à possibilidade de a assembléia geral de acionistas conceder, em favor de um ou mais acionistas, a emissão de Partes Beneficiárias, a qualquer tempo, por remuneração de serviços prestados à sociedade, independentemente de previsão dos estatutos, conforme artigo 87, parágrafo único, do Decreto-Lei n 2627 Assim, a fórmula da Lei $n^{\circ} 3150$ poderia não ser suficientemente ampla para enquadrar um caso como este, que não necessariamente estaria previsto nos estatutos.

A norma positivada no Decreto-Lei ${ }^{\circ} 2627$ só foi alterada com a promulgação da atual Lei das Sociedades por Ações Brasileira, cujo mandamento vale a pena novamente transcrever:

$\S 1^{\circ}$ o acionista não poderá votar nas deliberações da assembléia-geral relativas ao laudo de avaliação de bens com que concorrer para a formação do capital social e à aprovação de suas contas como administrador, nem em quaisquer

\footnotetext{
32 Apenas para constar, nota-se que a proibição de voto para a aprovação das contas como administrador foi mantida, no artigo 100 do Decreto-Lei no 2627: Artigo 100: “Instalada a assembléia geral proceder-se-á à leitura do relatório, do balanço, da conta de lucros e perdas e do parecer do conselho fiscal. O presidente abrirá, em seguida, discussão sobre esses documentos e, encerrada, submeterá à votação as contas da diretoria, o balanço e o parecer do conselho fiscal. Não poderão tomar parte na deliberação os membros da diretoria e do conselho fiscal".
} 
outras que puderem beneficiá-lo de modo particular, ou em que tiver interesse conflitante com o da companhia.

\section{2 - A Conceituação do Benefício Particular}

Traçados em linhas gerais os principais contornos históricos de formação do instituto do benefício particular, cumpre agora tentar construir suas bases conceituais, de modo a se poder definir com maior clareza seu âmbito de aplicação.

Nos últimos anos vêm se acentuando, principalmente no âmbito da Comissão de Valores Mobiliários, as discussões envolvendo a aplicação do instituto do benefício particular $^{33}$. Infelizmente, percebe-se que muitas vezes o operador do direito tem falhado na interpretação e/ou aplicação do referido instituto, justamente porque, ao que tudo indica, não estão efetivamente assentadas, no pensamento jurídico pátrio, as suas premissas essenciais de conceituação.

De fato, o benefício particular consiste em uma vantagem lícita ou ilícita? A obtenção da vantagem especial pressupõe a ocorrência de qualquer irregularidade ou prejuízos a qualquer pessoa? O benefício particular contempla apenas as vantagens pecuniárias auferidas pelo acionista ou toda e qualquer situação que lhe promova uma vantagem exclusiva? O benefício particular é toda e qualquer vantagem obtida pelo acionista ou somente aquelas em que puder auferir enquanto sócio da companhia?

Tais são, em linhas gerais, as indagações a que se pretende superar a partir da construção das bases conceituais do instituto em tela, conforme será visto a seguir.

\subsection{1 - O benefício particular como vantagem lícita}

A partir da breve análise das origens do instituto do benefício particular, percebe-se que o intuito maior do legislador foi criar certos procedimentos tendentes a impor arestas à

\footnotetext{
${ }^{33}$ Os posicionamentos da CVM sobre a matéria serão tratadas no terceiro capítulo desta dissertação.
} 
fixação de vantagens particulares a determinados indivíduos, sobretudo fundadores, quando da constituição da sociedade.

Conforme acima se adiantou, a doutrina francesa da época, tal como RIVIÈRE, relata que era muito comum, no caso das sociedades comanditas por ações, no âmbito das quais o instituto foi primeiramente aplicado, formalizar-se o estatuto da sociedade, no momento de sua constituição, sem a presença de todos os acionistas, o que favorecia o abuso por parte daqueles que pretendiam estipular para si benefícios particulares e vantagens de qualquer natureza. Em suas próprias palavras, "Dans la commandite par actions l'acte de société est rédigé en l'absence des actionnaires; il n'y a point de controle, a point de vérification. Il n'en existe pas davantage quand les actionnaires viennent souscrire; c'est ce qui était autrefois la cause de tant d'abus et d'exagération dans la valeur des apports",34

Portanto, com base nos motivos pelos quais o legislador da época se pautou para a criação de tal instituto, quer parecer que tais "avantages" se tratavam de vantagens lícitas, legítimas, legalmente possíveis de serem estipuladas em prol de certos acionistas.

Com efeito, o fato de o legislador ter instituído um mecanismo para controlar e, frise-se, não proibir, a fixação de tais vantagens, torna evidente que sua estipulação não foi algo que o legislador quis afastar ou coibir, o que seria esperado na hipótese de um ato ilícito.

O legislador, ao criar referida sistemática trazida pelo artigo $4^{\circ}$ da Lei Francesa de 1867, tão somente intentou dar condições aos acionistas não-beneficiados de analisar e apurar os termos e as circunstâncias das vantagens que seria estipuladas, de modo a garantir que as vantagens concedidas seriam adequadas e pertinentes e não excessivas ou abusivas.

Nesse sentido, as palavras de DUVERGIER, proferidas nas discussões legislativas atinentes à Lei de 1867, no âmbito da Câmara de Paris, são esclarecedoras. O Comissário de Governo em questão, tratando da sistemática prevista no supra citado dispositivo, afirmou que

\footnotetext{
${ }^{34}$ RIVIÈRE, H. Op.cit. p. 24.
} 
o intuito da norma seria garantir que as estipulações fossem apenas honrosas, dignas e não excessivas ${ }^{35}$.

Com efeito, os juristas franceses da época entendiam que as vantagens mencionadas pela Lei Francesa de 24 de julho de 1867 consistiam em vantagens lícitas, tal como BOSVIEUX, o qual destaca que a Lei Francesa de 24 de julho de 1867 sedimentou o entendimento de que o benefício particular estaria atrelado à criação e concessão de direitos societários e/ou à atribuição de direitos de preferência sobre os fundos sociais ${ }^{36}$.

Na Alemanha, o entendimento também não era outro. De fato, HERZFELDER observa que há decisões assembleares movidas por interesses particulares que nem sempre afetam a sociedade, ocasionando muito mais a quebra de igualdade entre os acionistas do que um prejuízo à companhia, sendo que tais interesses particulares se diferem significativamente daqueles propriamente contrários à sociedade, passíveis de lhe causar algum prejuízo ${ }^{37}$.

O mesmo pode ser dito em relação ao direito pátrio. Pela técnica redacional utilizada pelo legislador do Império Brasileiro, quer parecer que o termo "vantagens" se referia somente a vantagens lícitas, podendo, ser, inclusive estipuladas nos estatutos ou

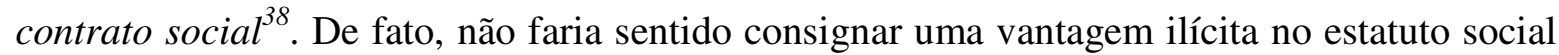
da companhia, de forma a materializar e legitimar a irregularidade ${ }^{39}$.

35 “Quand une seconde assemblée se réunit, elle représente la société, elle a pour mandat de vérifier l'apport a été sincère, justement estime, et si les avantages qui ont été stipulés l ont été honorablement. Quand majorité de cette assemblée, qui n'est pas réduite au quart, mais qui peut être de la totalité des actionnaires, s’ils veulent se donner la peine de s'y rendre, quand la majorité de cette assemblée a dit: Oui l'apport a été estimé à sa véritable valeur, oui les avantages stipulés l'ont été honorablement, ils $n$ ont rien d excessif, le vote de la seconde assemblée engage tout le monde" (RIVIÈRE, H. Op.cit. p. 89).

${ }^{36}$ BOSVIEUX, H. De La Notion D’Avantage Particulier. Journal des Sociétés, p. 65 et s. Apud Schimidt, D. Les Conflits D'Intérêts Dans La Société Anonyme. Paris: Joly, 2004, p. 98.

${ }^{37}$ HERZFELDER, F. Op.cit. p. 264.

${ }^{38}$ Era o caso, por exemplo, da vantagem mencionada no artigo $3^{\circ}, \S 3^{\circ}$ da própria Lei no 3.150 , que dizia: "É lícito, depois de constituída a sociedade, estabelecer-se em favor dos fundadores ou terceiros, que hajam concorrido com serviços para a formação da companhia, qualquer vantagem consistente em uma parte dos lucros líquidos".

${ }^{39}$ FRANÇA, tratando sobre o assunto, ensina que a norma em questão "não se reportava a quaisquer vantagens indevidas que porventura o acionista perseguisse, mas sim aos benefícios que a própria lei julgava lícito 
Com efeito, relembrando que o instituto do benefício particular foi criado para garantir que as vantagens especiais estipuladas a determinados acionistas fossem razoáveis, adequadas ou, nas palavras do político francês DUVERGIER, para assegurar que "les avantages stipulés l'ont été honorablement", tal como mencionado acima, realmente não faz qualquer sentido afirmar que o benefício particular possa corresponder a atos ilícitos.

Realmente, a finalidade do instituto foi apenas regrar uma situação que, à época, parecia estar desajustada, na medida em que era comum aos acionistas estipularem vantagens para si quando da constituição da sociedade, sem qualquer parcimônia ou controle.

Deste modo, pode-se afirmar que, interpretando o instituto do benefício particular sob a ótica histórico-teleológica, não há como não conceituá-lo como a vantagem lícita, que ordinariamente pode ser estipulada em favor de um determinado acionista.

Entretanto, não apenas a interpretação histórico-teleológica pode contribuir para tal conceituação. A própria interpretação lógico-sistemática da atual lei alemã e brasileira também conduz o operador do direito à mesma conclusão.

Como acima já se mencionou, o § 26 da Aktiengesetz de 1965 prescreve, em seu artigo 26, que cada vantagem especial concedida a um determinado acionista deverá estar fixada no estatuto social, juntamente com o nome do acionista beneficiado, sob pena de se tornar inválida tal estipulação.

O mesmo termo alemão que traduz o conceito de "vantagens especiais", qual seja, "Sondervorteile", pode ser novamente encontrado no $§ 253$, 2, da Aktiengesetz de 1965, o qual diz respeito à anulação das deliberações tomadas com o voto abusivo, ilegal.

outorgar em favor de fundadores ou terceiros" (Conflito de Interesses nas Assembléias de S.A. São Paulo: Malheiros, 1993, p. 70). 
O dispositvo alemão em tela prescreve que a anulação pode fundar-se no fato de um acionista, mediante o exercício de voto, ter tentado obter, para si ou para outras pessoas, vantagens especiais em detrimento da sociedade ou de outros acionistas ${ }^{40}$.

Assim, pode-se perceber que a legislação alemã indica a existência de duas espécies de Sondervorteile: aquelas que são obtidas em detrimento da sociedade e de outros acionistas e aquelas que podem ser licitamente estipuladas, desde que fixadas no estatuto social $^{41}$.

A primeira espécie de Sondervorteile é a ilícita, é a vantagem proibida pelo ordenamento jurídico, que poderá prejudicar a companhia, os acionistas ou terceiros, ao passo que a segunda espécie é a lícita, a permitida pelo ordenamento jurídico, bastando que esteja consignada no estatuto social da companhia quando de sua constituição.

A mesma constatação pode ser obtida a partir da análise da norma brasileira, que segue reproduzida:

Art. 84. O prospecto deverá mencionar, com precisão e clareza, as bases da companhia e os motivos que justifiquem a expectativa de bom êxito do empreendimento, e em especial:

$[\ldots]$

$V I$ - as vantagens particulares, a que terão direito os fundadores ou terceiros, e o dispositivo do projeto do estatuto que as regula;

Art. 115. $O$ acionista deve exercer o direito a voto no interesse da companhia; considerar-se-á abusivo o voto exercido com o fim de causar dano à companhia ou a outros acionistas, ou de obter, para si ou para outrem, vantagem a que não faz jus e de que resulte, ou possa resultar, prejuízo para a companhia ou para outros acionistas.

\footnotetext{
$40 \$ 243$, 2. Die Anfechtung kann auch darauf gestützt werden, daß ein Aktionär mit der Ausübung des Stimmrechts für sich oder einen Dritten Sondervorteile zum Schaden der Gesellschaft oder der anderen Aktionäre zu erlangen suchte und der Beschluß geeignet ist, diesem Zweck zu dienen.

${ }^{41}$ FRANÇA, E.V.A e N. Ainda o conceito de benefício particular: anotações ao julgamento do processo CVM $n$. RJ 2009/5811. Revista de Direito Mercantil, Industrial, Econômico e Financeiro n. 149/150, ano XLVII (Nova Série), jan/dez 2008, p. 316.
} 
$\S 1^{\circ} \mathrm{O}$ acionista não poderá votar nas deliberações da assembléia-geral relativas ao laudo de avaliação de bens com que concorrer para a formação do capital social e à aprovação de suas contas como administrador, nem em quaisquer outras que puderem beneficiá-lo de modo particular, ou em que tiver interesse conflitante com o da companhia.

$[\ldots]$

$\S 4^{\circ}$. A deliberação tomada em decorrência do voto de acionista que tem interesse conflitante com o da companhia é anulável; o acionista responderá pelos danos causados e será obrigado a transferir para a companhia as vantagens que tiver auferido.

A exemplo da legislação alemã, a norma brasileira identifica duas classes de vantagens que podem ser auferidas por acionistas: as vantagens a que o acionista não faz jus e que cuja obtenção possa resultar em prejuízo à companhia ou demais acionistas, bem como as vantagens particulares lícitas.

Com efeito, o termo "vantagens particulares" consignado no supra citado artigo 84, inciso VI, que trata das informações que devem ser fornecidas pelo prospecto no âmbito de uma constituição de companhia via subscrição pública, está se referindo, claramente, ao benefício lícito, o qual, inclusive, deverá constar, posteriormente, do estatuto da companhia.

Já a expressão "vantagem" trazida tanto pelo caput do mencionado artigo 115 como por seu parágrafo $4^{\circ}$ diz respeito à vantagem ilícita, aquela que o acionista não faz jus, e que possa resultar em prejuízo à companhia ou a outros acionistas.

Nesse cenário, o $\S 1^{\circ}$ do artigo 115 supra citado, quando prescreve que o acionista não poderá votar em deliberações que puderem beneficia-lo de modo particular, está se referindo a qual espécie de benefício ou vantagem? A lícita ou a ilícita?

Tudo leva a crer que o benefício mencionado pelo $\S 1^{\circ}$ do artigo 115 da Lei Acionária Brasileira diz respeito à vantagem lícita, tal como aquela prevista no artigo 84, inciso VI, do mesmo Diploma Legal. 
Isso porque, conforme se verá com maiores detalhes no próximo capítulo, o artigo 115 da Lei 6.404/76, ao regrar a relação entre os acionistas e a companhia, bem como entre os acionistas entre si, criou três institutos diversos, cada qual com sua função, reservando o tratamento da vantagem ilícita, a que o acionista não faz jus e que pode resultar em prejuízo à companhia e aos demais acionistas aos institutos do conflito de interesses e do voto abusivo, tal como se pode aferir da análise do caput e do $\S 4^{\circ}$ do artigo em questão.

De fato, considerando a redação do citado $\S^{\circ}$ do artigo 115 da Lei $n^{\circ} 6.404 / 76$, dispositivo aplicável às situações de interesses conflitantes, como não entender as vantagens que o acionista conflitado tem de devolver à companhia como sendo as de cunho ilícito, ou seja, as que ele não fazia jus (e até por isso que deve devolver)?

Assim, o dispositivo em tela achou por bem criar institutos diversos para regular situações diversas, reservando ao instituto do conflito de interesses e do voto abusivo o tratamento à vantagem ilícita, ao passo que o regramento da vantagem lícita foi atribuído ao instituto do benefício particular. Entender de modo diverso seria dar margem à confusão entre os institutos, desprezando a sistemática legal.

Deste modo, também por meio da interpretação sistemática da norma, fica claro que benefício particular previsto no $\S 1^{\circ}$ do artigo 115 da Lei $n^{\circ} 6.404 / 76$ diz respeito à vantagem lícita.

Portanto, a obtenção da vantagem concernente ao instituto do benefício particular não é irregular ou ilícita, bastando somente que os acionistas não beneficiados aprovem a concessão de tal vantagem. 
Destarte, se a instauração do benefício particular não pressupõe a ocorrência de irregularidade ou ilícito, forçoso concluir que sua realização não está associada à existência de qualquer prejuízo à companhia ou aos demais acionistas ${ }^{42}$.

Dito de outra forma, o que há no benefício particular é somente o intuito do acionista em ver aprovada determinada matéria que lhe possa resultar em uma vantagem lícita, não havendo que se falar em prática de qualquer irregularidade. Vale dizer, a "vantagem" do instituto do benefício particular, em sua essência, em sua origem, é de ordem lícita, pois não advém de uma irregularidade ou de um ato antijurídico.

Todavia, vale relembrar o que determina o $\S 1^{\circ}$ do artigo 109 da lei n. 6.404/76: "As ações de cada classe conferirão iguais direitos a seus titulares". Deste modo, não seria estranho indagar se a vantagem especial conferida a um determinado acionista de uma dada classe não estaria contrariando a norma acima, passando, assim, a ser ilícita?

A esse respeito, a interpretação sistemática da norma autoriza responder negativamente ao referido questionamento. Como se sabe, as normas não devem ser interpretadas isoladamente. Na visão de FERRAZ JR., "[...] qualquer preceito isolado deve ser interpretado em harmonia com os princípios gerais do sistema, para que se preserva a coerência do todo. Portanto, nunca devemos isolar o preceito nem em seu contexto (a lei em tela, o código: penal, civil, etc.) e muito menos em sua concatenação imediata (nunca leia só um artigo, leia também os parágrafos e os demais artigos" ${ }^{43}$.

Nesse sentido, se o $\S 1^{\circ}$ do artigo 115 da Lei $n^{\circ} 6.404 / 76$, ao menos indiretamente, previu a possibilidade de se instituir um benefício particular a determinado acionista, é porque a regra estabelecida no $\S 1^{\circ}$ do artigo 109 da mesma Lei comporta uma exceção,

\footnotetext{
42 Nesse sentido FRANÇA, o qual, tratando das possibilidades de sanção ao voto proferido em situação de benefício particular, admite que seja reconhecida a situação prevista pela norma independentemente da aferição de qualquer prejuízo à sociedade (Conflitos de Interesses nas Assembléias de Sociedades Anônimas. São Paulo: Malheiros, 1993, p. 91).

${ }^{43}$ FERRAZ JR. T.S. Introdução ao Estudo do Direito: Técnica, Decisão, Dominação, 3 ed. São Paulo: Atlas, 2001, p. 285.
} 
consubstanciada na vantagem especial atribuída a determinado acionista sem o voto participativo desse mesmo acionista.

Trata-se de mecanismo da legitimação, ou seja, a exceção à regra é legitimada por aqueles diretamente atingidos pelos efeitos da própria exceção. No caso do benefício particular, a regra do $\S 1^{\circ}$ do artigo 109 tem por intuito manter a igualdade de tratamento entre acionistas de mesma classe. Em teoria, assim, não seria permitida a instituição de uma vantagem particular a um acionista, em detrimento dos demais pertencentes a mesma classe. Essa regra, todavia, comporta uma exceção, admitindo a vantagem especial quando os acionistas que não serão beneficiados concordarem em conceder tal benefício a outro acionista.

A doutrina nacional e estrangeira compartilham desse mesmo entendimento.

Entre nós, é clara lição de FRANÇA: “O benefício particular é a vantagem lícita, que pode ser outorgada estaturiamente, mas que impede o acionista beneficiário de votar, porque não há condições de aferir se ela é equitativa ou não" 44.

Na França, cite-se o magistério de SCHMIDT, para quem o conceito de benefício particular está ligado à criação de direitos sociais ou a atribuição de um direito sobre os rendimentos ou sobre os fundos sociais, tratando-se, pois, de uma vantagem lícita ${ }^{45}$.

1.2.2 - O benefício particular como vantagem exclusiva e restrita que rompe a igualdade entre os acionistas e o preceito Nemo Iudex In Causa Propria

Os acionistas são iguais perante si. Tal princípio, inclusive, encontra-se positivado no ordenamento jurídico alemão ${ }^{46}$ e brasileiro ${ }^{47}$, como se viu acima.

\footnotetext{
${ }^{44}$ FRANÇA, E.V.N. O Conceito de Benefício Particular e o Parecer de Orientação 34 da CVM In. Temas de Direito Societário, Falimentar e Teoria da Empresa. São Paulo: Malheiros, 2009, p. 577.

${ }^{45}$ L'avantage particulier était lié a l'émission de droits sociaux ou à l'atribuition d'um droit de prélèvement sur les bénéficies et le fonds social (Les Conflits D’Intérêts Dans La Société Anonyme. Paris: Joly, 2004, p. 98).
} 
Os acionistas são iguais perante si por estarem todos submetidos à realização do escopo social, por pertencerem todos a uma mesma situação jurídica. Todos são acionistas e, ao realizarem seus investimentos em favor da companhia, esperam receber a devida contrapartida oportunamente. Esse intento comum, na visão de COMPARATO ${ }^{48}$, é que faz os acionistas serem iguais entre si e perante a Lei: "É, aliás, pela submissão de todos os sócios, sem exceção, ao escopo social comum que se realiza a verdadeira igualdade entre eles, igualdade evidentemente proporcional à participação de cada um no capital”.

Portanto, se são iguais, devem ser tratados de forma equitativa, não se permitindo que alguns sejam beneficiados e outros não. Os ônus e os bônus que couberem a um deverão, na qualidade de acionistas, necessariamente, ser estendidos aos demais, na exata proporção da suas participações societárias. É o que o F. Comparato denominou de Princípio da Justiça Distributiva $^{49}$.

Ademais, na linha do magistério de CANOTILHO ${ }^{50}$, conferir ou permitir tratamento diferenciado a indivíduos que compartilham de uma mesma situação jurídica, sem fundamento razoável, é romper a igualdade que deve prevalecer entre todos, enquanto detentores do mesmo status jurídico, é criar privilégios e, portanto, injustiças.

Nessa linha de entendimento, importante pontuar que o benefício particular consiste na vantagem atribuída a um ou alguns acionistas em específico, e não a toda a comunidade de acionistas. Exatamente por isso é que a vantagem ou benefício torna-se particular, exclusivo, restrito.

46 AKTG 1965, § 53a Gleichbehandlung der Aktionäre. Aktionäre sind unter gleichen Voraussetzungen gleich zu behandeln.

${ }^{47}$ Lei n. 6404/76, art. $109, \S 1^{\circ}$. As ações de cada classe conferirão iguais direitos aos seus titulares.

${ }^{48}$ COMPARATO, F.K. Controle Conjunto, Abuso no exercício do Voto Acionário e Alienação Indireta de Controle Empresarial In: Direito Empresarial: Estudos e Pareceres, 2a tiragem, São Paulo: Saraiva, 1995, p. 89.

${ }^{49}$ Ibdem, idem.

${ }^{50}$ CANOtilho, J. J G. Direito Constitucional e Teoria da Constituição. Coimbra: Almedina. 1995. p.403. 
Nesse ponto, a doutrina francesa é bastante esclarecedora, sendo interessante transcrever a visão de SCHMIDT, no sentido de que "A vantagem é particular porque, de um lado, beneficia somente uma ou algumas pessoas e, de outro, porque a vantagem não é comum. É comum aquela que pertence a todos os membros de um grupo. É particular aquela que não pertence ${ }^{, 51}$.

Da mesma forma, COZIAN, VIANDIER e DEBOISSY ensinam que o benefício particular é um favor exclusivo atribuído a uma ou algumas pessoas determinada(s), sendo expresso em termos intuitus personae, chegando mesmo a afirmar que as vantagens que são concedidas a uma específica classe de ações não podem ser consideradas como um benefício particular, pois não leva em consideração, para a estipulação, a pessoa de seus titulares ${ }^{52}$.

Deste modo, sendo o benefício particular aquela vantagem concedida exclusivamente e de modo restrito a apenas um ou alguns acionistas, tomando como base a pessoa de cada um, é evidente que sua estipulação causa a quebra da igualdade existente entre os acionistas.

A doutrina, nacional e estrangeira, corrobora essa vinculação do conceito de benefício particular ao rompimento da isonomia entre acionistas.

De fato, no Brasil, já dizia MIRANDA VALVERDE ${ }^{53}$ que o resultado que vier a beneficiar o acionista de modo particular quebrará "ainda que justo seja o tratamento, e a lei o permita, a regra de igualdade de tratamento para todos os acionistas da mesma classe ou categoria".

\footnotetext{
${ }^{51}$ SCHIMIDT, D. Le Conflits d'Intérêts dans la Société Anonymme. Paris: Joly, 2004, p. 52-53.

${ }^{52}$ COZIAN, M., VIANDIER, A. e DEBOISSY, F. Droit des Sociétés, 15 ed. Paris: LexisNexis, 2006, item 467.

${ }^{53}$ Op.cit., v. II, p. 67.
} 
Ainda no Brasil pode-se citar COMPARATO, para quem atribuir uma vantagem particular a determinado acionista significa "violar o princípio de igualdade relativa que consubstancia a justiça distributiva" ${ }^{, 54}$.

Grande estudioso do assunto, o qual elaborou votos de magna erudição acerca do tema no âmbito da Comissão de Valores Mobiliários, conforme adiante se tratará, SAMPAIO CAMPOS afirma que "o conceito de benefício particular está ligado diretamente ao conceito de igualdade entre os acionistas" ${ }^{\prime 55}$.

Por fim, para CARVALHO DE MENDONÇA, "Tudo o que rompe a igualdade que há, em princípio, entre os sociais, considera-se como vantagem particular”.

Na França, o tema não foi tratado de modo diverso. Com efeito, RIVIÉRE já afirmava que "l'appréciation et l'approbation de ces avantages sont exclusivement confiées aux assemblées générales qui sont appelées à prononcer non seulement surl'étendue mais encore sur la nature même des profits, prélèvements, avantages quelconques rompant $l$ équilibre entre les associes",56.

Da mesma opinião compartilha SCHIMIDT, o qual, também a partir da análise de juristas franceses no final do século XIX e início do século XX, ensina que o benefício particular consiste "en définitive tout droit et tout alocation ou rétribuition ayant pour effet de rompe l'egalité contractualle entre associes".

E mais adiante, o mesmo jurista francês, agora citando doutrina de LYON-CAEN e RENAULT, complementa ${ }^{57}$ :

"C.Lyon-Caen et L.Renault ensinam que 'tudo aquilo que rompe com a igualdade entre os acionistas constitui uma vantagem particular, e Cooper-Royer: 'de uma

\footnotetext{
${ }^{54}$ Ibdem, idem, p. 90.

${ }^{55}$ Voto proferido nos autos do Inquérito Administrativo CVM no TA RJ no 2001/4977 (termo de acusação), em dezembro de 2001.

${ }^{56}$ RIVIÉRE, H. Op.cit. p. 246.

57 Apud Schimidt, D. Le Conflits d'Intérêt dans la Société Anonyme, pp. 99.
} 
maneira geral, deve ser reconhecido que haverá vantagem particular sempre que a sociedade atribui a um sócio ou a certos sócios, ou, ainda, a determinados sócios futuros, um direito que contrarie o princípio da igualdade que deve orientar as relações dos acionistas um em relação aos outros."

O legislador teve por intuito estabelecer um mecanismo de controle para que as vantagens particulares não fossem concedidas sem qualquer controle ou critério.

De fato, como visto anteriormente, para justamente conter o excessivo uso da concessão, no âmbito inicialmente das sociedades comanditas por ações, das vantagens especiais ou, porque não dizer, privilégios $^{58}$, é que foi criado o instituto do benefício particular $^{59}$.

O legislador da época, percebendo a existência de abuso na estipulação de tais benefícios, os quais eram fixados sem qualquer critério, criou mecanismo que pudesse conferir aos demais acionistas não beneficiados a oportunidade de analisar a adequação e razoabilidade de tais vantagens, afastando da deliberação que teria por fim aprová-las os acionistas beneficiados, como a legitimar a quebra da igualdade que, de todo modo, ocorrerá.

Deste modo, conclui-se que a ratio legis do instituto do benefício particular, legitimadora, por assim dizer, da quebra da igualdade existente entre os acionistas, está assentada no preceito Nemo Iudex In Causa Propria, na medida em que o instituto tem por intuito evitar que o acionista tome partido a seu próprio favor, evitando os inconvenientes de uma pessoa julgar os próprios atos e decidir sobre algo que lhe diga respeito diretamente e pode lhe beneficiar.

\footnotetext{
${ }^{58}$ Conforme se verá oportunamente, o benefício particular consiste em um privilégio recebido pelo acionista, que recebe mais do que dá.

${ }^{59}$ Com efeito, como já ensinava MIRANDA VALVERDE, "a causa ou fundamento da atribuição, a um ou mais acionistas, de vantagens, que rompem, ainda que temporariamente, com o princípio da igualdade de tratamento, há de ser séria, justa, razoável" (Sociedade por Ações, Vol. II, 2. ed. Rio de Janeiro: Forense, 1953, p. 66/67). Para analisar se as tais vantagens eram "sérias, justas e razoáveis" é que foi criado o instituto do benefício particular.
} 
Com efeito, desde suas origens, a doutrina francesa já salientava esse ponto, tal como RIVIÉRE, o qual afirmava que: “l'actionnaire qui vote sur ses propres apports n'est évidemment pas dans les mêmes conditions $d$ indépendance et d impartialité que les autres associes" $" 60$.

No Brasil, tal fato não foi diferente, tendo a doutrina, desde o início do século XX, já apontado nesse sentido, tal como se pode aferir da lição de MIRANDA VALVERDE ${ }^{61}$ : “ $A$ Lei presume que o subscritor [...] não pode julgar, com a necessária imparcialidade, o laudo de avaliação dos seus bens e valores. Segue, pois, orientação geral em casos semelhantes, e, isso, com o objetivo de cortar as asas da fraude. Também não pode o acionista, pela mesma razão, votar nas deliberações da assembléia geral sobre matéria que o venha beneficiar de modo particular"

LOPES PONTES ${ }^{62}$, por sua vez, fundamentava o instituto do benefício particular em preceito de ordem moral: “É defeso, outrossim, aos acionistas, por medida de moralidade, votar nas deliberações da assembléia geral que venham a beneficia-lo de modo particular, que por si próprios, quer por meio de procuradores".

Por fim, cite-se o magistério de CARVALHO DE MENDONÇA ${ }^{63}$ : "Em hipótese alguma, as vantagens aos fundadores ou a terceiros podem ser estabelecidas pelos próprios fundadores ou pelos administradores da sociedade, porém, somente, pela assembléia geral dos acionistas depois de constituída a sociedade. Os fundadores, se também subscritores ou acionistas, não podem constar na qualidade de acionistas, nas deliberações sobre quaisquer vantagens estipuladas em seu favor nos estatutos ou no contrato social”.

\footnotetext{
${ }^{60}$ RIVIÉRE, H. Op.cit. p. 88.

${ }^{61}$ VALVERDE, T. de M. Sociedade por Ações, Vol. II, 2. ed. Rio de Janeiro: Forense, 1953, p. 66/67.

${ }^{62}$ PONTES, Aloysio Lopes. Sociedades Anônimas, Vol. I, 3. ed. Rio de Janeiro: Forense, 1954, p. 430/431.

${ }^{63}$ MENDONÇA, J.X. Carvalho de. Tratado de Direito Comercial Brasileiro, Vol. II, atualizado por Ricardo Negrão. Campinas: Bookseller, 2000, p. 346/349.
} 
No entanto, cumpre ressalvar que, a partir da promulgação da Lei Francesa de 24 de julho de 1966, a questão do reconhecimento do benefício particular como aquela vantagem que poderia romper a igualdade constante entre os acionistas foi parcialmente alterado.

Isso porque o artigo 80 da supra citada Lei alargou o elenco dos possíveis beneficiados de tais vantagens especiais, fazendo constar, além dos acionistas, quaisquer terceiros que pudessem ser beneficiados particularmente.

Assim, para alguns autores, se o benefício particular pode ser atribuído a qualquer terceiro, não é somente toda e qualquer vantagem que rompe com a igualdade entre os acionistas que deve ser considerada como benefício particular, pois, na hipótese de um terceiro ser beneficiado, não haverá qualquer alteração na relação de igualdade entre os acionistas em $\mathrm{si}^{64}$.

Desta maneira, ganhou força o entendimento consignado pela Corte de Cassação Francesa, em acórdão proferido em 6 de março de $1935^{65}$, no sentido de que não basta que a vantagem rompa com a igualdade entre os acionistas, é preciso, antes de tudo, que a vantagem conceda ao beneficiado uma preferência sobre os fundos sociais e seus produtos, tal como se verá no item a seguir ${ }^{66}$.

$\underline{1.2 .3 ~-~ O ~ b e n e f i ́ c i o ~ p a r t i c u l a r ~ c o m o ~ a t o ~ d e ~ l i b e r a l i d a d e ~ q u e ~ r o m p e ~ c o m ~ o ~ i n t e r e s s e ~ c o m u m ~ d o s ~}$ acionistas e interfere no acesso aos fundos sociais

Pela análise realizada até o presente momento, quer parecer que o conceito de benefício particular está atrelado a uma vantagem de ordem lícita, atribuída exclusiva e restritivamente a determinado acionista ou parcela de acionistas, tendente a romper, na maioria das vezes, a igualdade existente entre os acionistas.

\footnotetext{
${ }^{64}$ SCHIMIDT, D. Op.cit. p. 100.

${ }^{65}$ A análise do aludido acórdão da Corte de Cassação Francesa será realizada no tópico seguinte.

${ }^{66}$ Schmidt, D. Op.cit. p. 99-100.
} 
No entanto, as vantagens lícitas atinentes ao benefício particular são apenas aquelas que o acionista poderia obter enquanto sócio da companhia ou em seu bojo pode ser compreendido toda e qualquer vantagem, desde que lícita? Ainda, as tais vantagens lícitas devem ser necessariamente de ordem pecuniária?

A questão vem sendo debatida pelos operadores do direito já há algum tempo ${ }^{67}$, formando-se duas correntes de pensamento.

A primeira corrente defende que o benefício particular só pode ser uma vantagem atribuída ao acionista na qualidade de sócio, afastando, por assim dizer, eventuais vantagens auferidas por um sócio na qualidade de credor da companhia. Já a segunda corrente entende que o benefício particular corresponde a toda e qualquer vantagem recebida por um acionista não compartilhada com os demais.

Em termos práticos, os partidários da primeira corrente, dentre os quais se pode citar o Ex-Diretor da Comissão de Valores Mobiliários Luiz Antônio de Sampaio Campos, entendem que, entre um acionista e um credor, por exemplo, os direitos e deveres que competem a cada um são distintos entre si, já que as relações jurídicas que mantêm com a companhia são também diversas entre si, o que justifica um tratamento diferenciado.

Assim, nessas condições, se o sócio-credor receber um determinando bônus, na qualidade de credor, que os demais acionistas, na qualidade de acionista, não receberam, não haveria que se falar, em termos técnicos, de benefício particular, pois não houve qualquer quebra da igualdade entre ambos. Em outras palavras, o bônus recebido pelo sócio-credor é decorrente da relação jurídica de credor que mantém com a companhia. O simples acionista,

\footnotetext{
67 Nesse sentido, vide Inquérito Administrativo CVM nº TA/RJ2001/4977 e Processo Administrativo $n^{\circ}$ RJ 2009-13179.
} 
que não mantém relação jurídica de credor com a sociedade, mas de apenas sócio, não faria jus a esse bônus.

Nas palavras do próprio Diretor:

"Dito de outra forma, a questão do benefício particular, da vantagem, decorre do tratamento do acionista na qualidade de acionista, e não em outra situação em que eventualmente se encontre o acionista, pois, nessa hipótese, parece-me enquadrar $o$ conflito de interesses.Tal, a meu ver, não se confunde, contudo, com o pagamento de uma contraprestação ou exercício de um direito de acionista pelo acionista. Assim é que o pagamento ao acionista relativamente a um contrato não rompe essa igualdade, uma vez que o valor que este acionista receberá será a contraprestação do objeto do contrato. Não recebe ele esse valor por ser acionista, nem celebra ele o contrato por ser acionista. $O$ ponto central parece-me ser que aqueles que se encontram na mesma situação jurídica perante a companhia, na qualidade de acionista, devem ser tratados igualmente ${ }^{, 68}$.

Assim, quer parecer que a conclusão do supra citado jurisconsulto é no sentido de que se fossem todas e quaisquer vantagens consideradas como benefício particular, não haveria que se falar em quebra de igualdade, pois não se estaria lidando com situações jurídicas idênticas, a ensejar idêntico tratamento.

Já para os partidários da segunda corrente, dentre os quais se destaca a posição do Diretor da Comissão de Valores Mobiliários Marcos Pinto Barbosa, o benefício particular seria toda e qualquer vantagem atribuída a determinado acionista, independentemente de sua própria condição de acionista. Confira-se:

"Discute-se, a propósito, se ela se restringe ao benefício particular recebido pelo acionista, na sua qualidade de acionista, que rompe a igualdade entre os sócios, ou se abrange qualquer benefício a ser concedido por conta da deliberação, ao acionista, que não seja extensivel aos demais. Nesse ponto, parece-me mais acertada a segunda posição, pelas mesmas razões que foram manifestadas pelo Ex-Presidente Marcelo Trindade em seu voto no julgamento do Inquérito Administrativo RJ2001/4977. Com efeito, sob pena de se adotar uma interpretação vazia de utilidade prática e em descompasso com a atual realidade das companhias abertas, entendo que o acionista está impedido de votar toda vez que

\footnotetext{
${ }^{68}$ Voto proferido nos autos do Inquérito Administrativo CVM n ${ }^{\circ}$ TA/RJ2001/4977.
} 
da deliberação possa resultar a seu favor um benefício particular, ou seja, que não seja extensível aos demais acionistas"

Para essa segunda corrente, conceituar o benefício particular como apenas as vantagens que o acionista poderá obter na qualidade de acionista seria "se adotar uma interpretação vazia de utilidade prática e em descompasso com a atual realidade das companhias abertas”, conforme acima afirmou Marcos Barbosa.

Entretanto, quer parecer que a razão está com os partidários da primeira corrente.

Isso porque, em primeiro lugar, a partir da interpretação histórico-teleológica do instituto, como já se viu, verifica-se que as vantagens a que o legislador se preocupou em regrar quando criou o instituto do benefício particular eram vantagens de cunho social, que o acionista somente poderia obter na qualidade de acionista, no momento da constituição da sociedade. Com efeito, o legislador, em suma, tinha por intuito regrar matérias reservadas a aportes e concessões de liberalidades de um modo geral, as quais poderiam ser estipuladas pelos fundadores quando da constituição da companhia.

Ademais, alargar o conceito de benefício particular a toda vantagem recebida pelo acionista, independentemente de sua condição de acionista, seria desprezar a própria estrutura

69 Voto proferido nos autos do Processo Administrativo $n^{\circ}$ RJ 2009-13179.. Neste mesmo caso, a Presidente Maria Helena Cardoso, assim se manifestou: "Durante muito tempo, entendeu-se que a hipótese de impedimento de voto por benefício particular, prevista no art. $115, \$ 1^{\circ}$, aplicar-se-ia apenas às vantagens concedidas aos acionistas enquanto sócios da companhia. Todavia, conforme ressaltei no Caso Duratex, essa posição não encontra amparo na Lei $n^{\circ}$ 6.404, de 1976. Quando a lei impede o acionista de votar em situaçóes 'que puderem beneficiá-lo de modo particular', sua hipótese de incidência não se restringe às vantagens recebidas pelo acionista enquanto sócio. Seu campo de aplicação é muito mais amplo, alcançando qualquer vantagem de que goze apenas um acionista. Um contrato entre o acionista e a companhia faz justamente isso: ele beneficia o acionista contratante de modo singular". Em oportunidade anterior, Marcelo Trindade, no julgamento do Inquérito Administrativo RJ 2001/4977, já havia consignado: "Na verdade, embora a doutrina sempre considere $o$ benefício particular a que se refere o $\$ 1^{\circ}$ do art. 115 como um benefício na qualidade de acionista, tal assertiva parece irrealística, dado que a própria lei, dentre os direitos essenciais dos acionistas, incluiu o de serem tratados de maneira idêntica, quando detentores da mesma classe e espécie de ações. Tal regra levaria quase sempre á nulidade da deliberação assemblear que pretendesse conferir direitos especiais a certos acionistas, independentemente da discussão sobre o impedimento de voto.A mim me parece que, embora tratando de benefício particular, quis a lei extremar uma hipótese mais ampla que as anteriores [...] a qual ocorre sempre que se possa atestar prévia a e induvidosamente que a deliberação trará benefícios ao acionista, não extensível aos demais e á companhia". 
e interpretação lógico-sistemática do artigo 115 da Lei n ${ }^{\circ}$ 6.404/76, que regrou, por meio de institutos distintos, situações distintas, dentre as quais aquelas em que o acionista pode auferir vantagem extrassocial.

Com efeito, dentro da estrutura construída pelo artigo 115 da Lei n. 6404/76, situações envolvendo contratações entre acionista e companhia, hipóteses em que se está presente, portanto, a obtenção de vantagens extrassociais, devem ser analisadas sob a ótica do conflito de interesses e não do benefício particular, uma vez que a posição dupla (de acionista e credor) ocupada pelo acionista frente à companhia, além de poder ensejar a existência de interesses diversos do interesse social, podendo, assim, gerar situações de conflito, o coloca em patamar distinto em relação aos demais acionistas que não são credores, já não mais se podendo falar em isonomia entre eles e, por conseguinte, em eventual quebra a dar azo ao benefício particular.

Vale dizer, se duas pessoas são sócias e uma delas celebra um contrato com a sociedade, passará a deter direitos em relação à sociedade que a outra sócia não detém. Assim, o que a sócia-credora receber enquanto credora não se constitui um benefício particular em relação à outra sócia, já que a vantagem não é oriunda da mesma relação jurídica.

Entretanto, as discussões não se esgotam nesse ponto. O problema que se coloca é se a própria criação de uma relação jurídica distinta poderia ensejar o benefício particular ou, em outras palavras, se o próprio fato de o sócio contratar com a sociedade já não é, de per si, um rompimento da igualdade que existe entre eles.

Para tratar da questão, vale relembrar que, conforme acima se mencionou, a Lei Francesa de 24 de julho de 1966 veio dar novos ares ao conceito de benefício particular ao tornar-se aplicável não mais apenas aos acionistas, mas também a qualquer terceiro ${ }^{70}$,

\footnotetext{
${ }^{70}$ Vide Nota de Rodapé n. 22.
} 
impulsionando o entendimento de um antigo acórdão proferido pela Corte de Cassação Francesa em $1937^{71}$.

O tema tratado por este acórdão diz respeito à vantagem concedida a dois acionistas da companhia por não estarem submetidos ao procedimento de aprovação e preferência de compra por parte dos demais acionistas na hipótese de alienação de suas ações. A questão era saber se tal vantagem consistia em um benefício particular e, por isso, deveria ser submetida ao mecanismo de aprovação previsto na Lei Francesa de 1867.

Apreciando a controvérsia, a Corte Francesa entendeu que a vantagem em tela não poderia ser caracterizada, tecnicamente, como benefício particular, uma vez que tal vantagem, muito embora quebrasse a relação de igualdade existente entre os sócios, em nada interferia no direito dos demais acionistas sobre os fundos sociais e seus produtos ${ }^{72}$.

De acordo com a Corte Francesa, para o acionista alienante, o fato de não estar submetido à aprovação ou à preferência de compra dos demais acionistas não pode ser considerada uma vantagem que lhe conceda um direito sobre os fundos sociais, privilegiando$\mathrm{o}$, neste ponto, frente aos demais acionistas.

Assim, principalmente após a citada Lei Francesa de 1966, que, ao estender a aplicação do benefício particular a sócios e não sócios, acabou por tornar insuficiente para a caracterização do instituto a mera quebra de isonomia entre acionistas, o conceito de benefício particular passou a estar atrelado também ao direito dos demais acionistas aos fundos sociais e seus produtos, ou seja, o patrimônio da companhia e os lucros obtidos com a realização de seu objeto social.

\footnotetext{
${ }^{71}$ Importante mencionar que apesar de o parágrafo primeiro do artigo 115 da Lei n. 6.404/76 não ter instituído a hipótese de atribuição de benefício particular a terceiros que não sejam acionistas, ao contrário da Lei Francesa de 1966 e do atual Code de Commerce, de grande valia para o enriquecimento da conceituação do instituto as discussões que decorreram de tal fato, de modo que passam a ser utilizadas no presente trabalho.

72 "Le droit octroyée à deux actionnaires de ne pas suivre la procédure d'agrément applicable aux autres constitue un avantage qui ne peut avoir aucune influence relativement aux droits de autres actionnaires sur les fonds social et sur produits et ne constitue donc pas um avantage particulier au sens de l'article 4 de la loi du 24 juillet 1867" (Schmidt, D. Op.cit, p. 100).
} 
Em outras palavras, o aplicador do direito ganhou outro instrumento para análise da caracterização do benefício particular, consistente na observação se a vantagem concedida a dado acionista em particular tem o condão de interferir diretamente nos direitos dos demais acionistas sobre o patrimônio da companhia e seus frutos, ou seja, verificar se vantagem concedida a determinado acionista se traduz em um direito sobre os fundos sociais que o privilegie, neste ponto, em relação aos demais acionistas.

Destarte, quer parecer que, mesmo que a natureza do benefício particular não seja necessariamente pecuniária, sempre deverá ter impacto, ao menos de forma indireta, nos direitos dos demais acionistas sobre o patrimônio da companhia e seus frutos.

A título de exemplo, conceder a determinado acionista, independentemente de qualquer disposição legal, de sua participação societária ou qualquer outra contribuição realizada, o direito de preferência em relação à aquisição das ações pertencentes aos demais acionistas, por exemplo, não tem natureza originalmente pecuniária, mas, por outro lado, poderá interferir nos direitos dos demais acionistas sobre os fundos sociais, na medida em que o acionista, ao exercer tais direitos, poderá aumentar sua participação societária permitindo, com isso, maior acesso aos fundos sociais ${ }^{73}$.

Visto deste modo, fica muito claro que o benefício particular pode ser considerado como toda vantagem lícita que tenha condições de causar um desequilíbrio da chamada Justiça Distributiva, conceito criado COMPARATO, tal como acima se abordou ${ }^{74}$.

\footnotetext{
${ }^{73}$ Interessante notar que MARTINS não considera como benefício particular o fato de um acionista poder elegerse como membro do conselho de administração de sua companhia. Para o referido autor, as vantagens decorrentes da remuneração que seriam atribuídas ao acionista não podem ser tratadas como benefício, mas como uma retribuição a um encargo que lhe foi entregue (Martins, F. Comentários à Lei das Sociedades Anônimas: Artigo por artigo, $4^{\mathrm{a}}$ Ed. Rio de Janeiro: Forense, 2010, p. 398). Com razão o Professor Cearense em relação a esse ponto, pois a remuneração não pode ser considerada benefício particular pois, antes de mais nada, lhe falta o aspecto da liberalidade, da gratuidade, inerente ao instituto. No entanto, não se pode esquecer que a principal vantagem de tal fato não é perceber a remuneração, mas passar a ter maior ingerência sobre o patrimônio da companhia, sobre os fundos sociais. Assim, eleger ou ser eleito membro do conselho de administração não é um benefício particular, mas ganhar esse direito, gratuitamente, independentemente de qualquer circunstância ou justificativa, faz dessa vantagem um benefício particular.

${ }^{74}$ COMPARATO, F.K. Controle Conjunto, Abuso no exercício do Voto Acionário e Alienação Indireta de Controle Empresarial In: Direito Empresarial: Estudos e Pareceres, $2^{a}$ tiragem, São Paulo: Saraiva, 1995, p. 89.
} 
De fato, se todos os acionistas contribuem, na exata medida de suas participações societárias, ao capital social de uma companhia, o que se espera é que todos possam retirar do patrimônio social, periodicamente, exatamente aquilo que têm direito, conforme a participação de cada um.

Segundo SCHMIDT, é exatamente nisso que consiste o interesse comum dos sócios: realizar o objeto social e retirar do patrimônio comum a parcela de riqueza a que faz jus, de acordo com sua contribuição quando da constituição da companhia ${ }^{75}$.

Assim, se algum sócio retira parcela extra do patrimônio social, além da quota a que ordinariamente teria direito, conforme sua participação, está rompendo o interesse comum dos sócios , ensejando, pois, a caracterização do benefício particular. Mais uma vez utilizandose das palavras do mestre francês ${ }^{76}$, "pode-se considerar como vantagem particular sempre que uma pessoa retira da sociedade direito ou o ganho que não compartilha com os seus sócios".

Em outra passagem, SCHMIDT é ainda mais preciso, valendo transcrever o texto em sua linguagem original ${ }^{77}$ :

"Cet interét s'entend du droit de chaque associé de retirer um enrichissement personnel de la richesse sociale laquelle réside precisemént dans les fonds social et ses produits. Le lien entre l'avantage particulier et intérêt commun apparaît alors avec évidence, puisque tous deux portent exactement sur lês fonds social et sus produits. Or accorder à um bénéficiaire um droit sur ces actifs que ne lui confère pás as seule qualité d'actionnaire et d'apporteur, c'est rompre l'intérêt commun; de même, accorder à um 'tiers' um droit sur ces actifs, c'est admetrre um étranger à partager um droit qui n'appartient qu'aux seuls associes. Dans tous ces cas, l'avantage octroyé au bénéficiaire rompt la communauté d'intérêt sur lês fonds social et ses produits.”

\footnotetext{
75“'L'intérêt de tout associé étant de retirer sa part légitime de l'enrichissement social, l'intérêt commum de associes reside dans la réalisation et le partage entre eux dês profits de la société. Ils entendent tous que la société réalise des profits et que ceux-ci soient partagés à proportion de ce qui revient à chacun". Schmidt, D. Op.cit, p. 2-3.

${ }^{76}$ SCHIMIDT, D. Le Conflits d'Intérêts dans la Société Anonymme. Paris: Joly, 2004, p. 95-96.

${ }^{77}$ Ibdem, idem, p. 100-101.
} 
Assim, se todos os sócios têm o direito de retirar do patrimônio social a exata contrapartida de suas contribuições, aquele que retira além dessa contrapartida está sendo beneficiado particularmente. Então, fica claro que o conceito do benefício particular ganha contornos de liberalidade, de favor, tratando-se, pois, de vantagem concedida gratuitamente.

A utilização da liberalidade/gratuidade como parâmetro para caracterização do benefício particular parece encontrar guarida sólida na doutrina francesa. Com efeito, COZIAN, VIANDIER e DEBOISSY são expressos em afirmar que o benefício particular consiste em um favor concedido a uma pessoa determinada, valendo transcrever suas próprias palavras: ${ }^{78}$ :

"L'avantage particulier est une faveur atribuée à une personne dénomméé. Semblable definition conjugue deux elements: l'existence d'une faveur et la référence à une personne denommée.

[...]

Il ne saurait y avoir avantage particulier sans faveur ou privilège. C'est la raison pour laquelle les juges insistent sur l'idéé de rupture d'egalité. On observera que la nature - pecuniaire ou non - de l'avantage est indifférente [...] Également, la qualité des l'attributaire importe peu; Il peut s'agir selon l'article L.225-8 d'um associe ou d'um tiers"

Deste modo, o benefício particular deve ser visto como a vantagem recebida pelo acionista que não encontra contrapartida em seu aporte realizado quando de seu ingresso na sociedade, ou, nas palavras de SCHIMDT, o "faveur pour la bénéficiaire qui reçoit plus qu'il done, ${ }^{, 79}$.

Assim, o mero acesso por parte de um acionista ao patrimônio social e a seus produtos não configura o benefício particular; para tanto, o acesso deverá ser concedido como um favor, uma liberalidade, e, se não de forma gratuita, com oferecimento de contrapartida

\footnotetext{
${ }^{78}$ COZIAN, M., VIANDIER, A. e DEBOISSY, F. Droit des Sociétés, 15 ed. Paris: LexisNexis, 2006, item 467.

${ }^{79}$ SCHIMIDT, D. Op. cit. 103. Entre nós, o Professor Erasmo Valladão compartilha de tal entendimento, ensinando que para a configuração do benefício particular "há de haver, assim, um favor ao beneficiário, na sua condição de acionista, que recebe mais do que dâ"(Temas de Direito Societário, Falimentar e Teoria da Empresa. São Paulo: Malheiros, 2009, p. 576).
} 
insuficiente para justificar tal acesso. Isso porque retirar parcela da riqueza social correspondente à prestação disponibilizada à companhia não é benefício particular, haja vista que não pode haver vantagem em relações equitativas, no qual uma parte não recebe mais do que dá: “Allors, Il n’y a pas avantage mais prestations équilibrées" 80.

Feitas todas essas considerações, percebe-se que o ato de contratação de um acionista em face de sua sociedade não pode ser considerado como um benefício particular na medida em que, por mais que possa haver uma quebra inicial da igualdade entre os acionistas pelo fato de um deles ter a oportunidade de deixar a condição de mero acionista e passar a ser acionista-credor, tal quebra de igualdade não vem acompanhada da necessária liberalidade, pois o acionista, para se tornar sócio-credor, terá de, em contrapartida à contratação, prestar à companhia todas as condições necessárias para que tal contratação seja satisfeita, não se tratando, pois, de um favor.

Por fim, dado que o benefício particular deve ser visto como a liberalidade, o favor concedido a um determinado acionista, não pode ser considerado como tal aquelas vantagens fixadas pela lei a determinadas classes de ações: "Lorsque l'avantage est instittué per la loi, il n'y a pas a avantage particulier" ${ }^{\prime \prime 1}$.

\footnotetext{
${ }^{80}$ Exemplo de vantagem que não pode ser considerada benefício particular por faltar-lhe o aspecto da liberalidade é a eleição pelo acionista de um membro do conselho de administração da companhia. MARTINS não considera como benefício particular o fato de um acionista poder eleger-se como membro do conselho de administração de sua companhia. Para o referido autor, as vantagens decorrentes da remuneração que seriam atribuídas ao acionista não podem ser tratadas como benefício, mas como uma retribuição a um encargo que lhe foi entregue (Martins, F. Comentários à Lei das Sociedades Anônimas: Artigo por artigo, $4^{\mathrm{a}}$ Ed. Rio de Janeiro: Forense, 2010 , p. 398). Apesar de bastante discutido pela doutrina (Valverde, Sociedade por Ações, V. II, p. 68; Cunha Peixoto, Sociedade por Ações, v. II, p. 362;Carvalhosa, Comentários à Lei das S/A, V. II, p. 116; Fran Martins, Comentários à Lei de Sociedades Anônimas, p. 398.), não pode ser considerado como benefício particular a participação nos lucros dos administradores-acionistas (art. 152, $§ 1^{\circ}$, da Lei n. 6.404/76), justamente por também faltar-lhe a gratuidade, já que nada mais representam do que "contraprestações de serviços prestados à sociedade".
}

${ }^{81}$ COZIAN, M., VIANDIER, A. e DEBOISSY, F. Droit des Sociétés, 15 ed. Paris: LexisNexis, 2006, item 467. 


\subsection{4 - Conclusões sobre a Conceituação do Benefício Particular}

Realizada essa breve incursão história e analítica sobre as origens e características do instituto do benefício particular, poder-se-ia conceituá-lo da seguinte forma: o benefício particular consiste na vantagem lícita, de natureza pecuniária ou não, concedida como ato de mera liberalidade a determinado acionista ou grupo de acionistas, na qualidade de acionista e em caráter intuitus personae, que tem o condão de romper a igualdade e o interesse comum existente entre os demais acionistas, interferindo em seu alcance aos fundos sociais, seus produtos e direitos ${ }^{82}$.

A contrario sensu, não pode ser considerada como benefício particular a vantagem obtida pelo acionista como contrapartida de sua contribuição prestada ou mesmo a vantagem recebida pelo acionista por força de lei. Também não deve ser considerada como benefício particular a vantagem extrassocial auferida pelo acionista, oriunda de relação diversa da societária mantida com a companhia.

\footnotetext{
${ }^{82}$ Para fins de evitar eventuais dúvidas que a terminologia poderia criar, cumpre esclarecer que o benefício particular tratado no presente trabalho não se confunde com o que a doutrina norte-americana denomina private benefits. $\mathrm{O}$ conceito de private benefits está relacionado ao ganho ou vantagem atribuído exclusivamente ao acionista controlador, ou, no caso de companhias com diluição acionária, ao administrador, simplesmente por deter o controle de uma companhia (DYCK, A e ZINGALES, L. Private Benefits of Control: An International Comparison. The Journal of Finance, v. LIX, n. 2, abril/2004, p. 7; HWANG, J.H. Whose Private Benefits of Control? Owners or Managers?, Agosto de 2004, p. 1, disponível em www. fdic.gov/bank/analytical/CFR/2004/set/CFRCP_2004-03-hwang.pdf.). A doutrina costuma associar os ganhos e vantagens do private benefits a eventos de natureza diversa, tais como gratificações pagas com recursos da companhia, utilização de informação para fins de usurpar oportunidades de negócios da companhia, vantagens auferidas no âmbito de operações com partes relacionadas, transferência de ativos para outra sociedade do controlador, transferências de ganhos em reestruturações societárias, etc. (DYCK, A e ZINGALES, L. Op.cit, p. 7; HOLMEN, M e KNOPF, J. D. Minority Shareholder Protections and the Private Benefits of Control for Swedish Mergers. Journal of Financial and Comparative Analysis, v. 39, n. 1, março/2004, p.168-169). Caracteriza-se, portanto, como todo e qualquer ganho ou vantagem que o acionista controlador ou administrador podem auferir, de forma lícita ou ilícita, pelo fato de deterem o controle da sociedade. Estudos demonstram que países onde a legislação prestigia direitos de acionistas minoritários e estabelece padrões rígidos de contabilidade, bem como onde o mercado seja mais competitivo, as chances de obtenção do private benefits são menores (DYCK, A e ZINGALES, Op.cit, p. 37; HOLMEN, M e KNOPF, J. D., p. 167). Economicamente, o private benefits pode ser mensurado como o prêmio de controle, ou seja, a diferença entre o preço pago pelas ações de controle e o preço das demais ações da companhia (DYCK, A e ZINGALES, Op.cit, p.8). Portanto, por mais que a terminologia possa confundir, o conceito de private benefits, além de ser mais amplo do que o conceito de benefício particular positivado na legislação pátria, assume outra vertente, relacionando-se aos ganhos de qualquer natureza associados ao poder de controle.
} 
Estabelecidos assim os contornos conceituais do instituto do benefício particular, torna-se possível compará-lo com outros institutos bem como definir sua abrangência de atuação, como será feito no capítulo seguinte.

Todavia, antes de se adentrar nesse mérito, cumpre tratar do principal efeito prático do benefício particular, o impedimento de voto, bem como das consequências advindas pela violação à regra legal.

\section{3 - Efeitos do Benefício Particular: o Impedimento de Voto}

Estabelecidos os contornos da conceituação do instituto do benefício particular, já é possível tecer alguns comentários sobre um de seus principais efeitos, o impedimento do exercício do direito de voto pelo acionista particularmente beneficiado.

O $\S 1^{\circ}$ do artigo 115 da Lei 6.404/76 impõe a vedação ao voto do acionista em certas situações, dentre as quais aquelas em que puder beneficiá-lo de modo particular. Entende-se que, com isso, o legislador quis evitar que o acionista beneficiado exclusivamente pudesse contribuir, com seu voto, para a aprovação de tais vantagens.

Assim, fica claro que a Lei buscou prevenir a possibilidade de o interesse particular do acionista prevalecer nessas deliberações, de modo a garantir a satisfação e o cumprimento dos mais comezinhos princípios informadores do direito, de modo a reverenciar a lisura na relação entre os agentes societários, que se traduz, nas palavras de MAGALHÃES, no exercício limpo e claro dos direitos e no repúdio às reservas ocultas e veladas de conveniência pessoal ou de grupos ${ }^{83}$.

Desta forma, conforme acima se adiantou, o fundamento do impedimento de voto por benefício particular encontra-se calcado em preceitos de ordem ética, os quais têm por

\footnotetext{
${ }^{83}$ MAGAlHÃES, R.B. A Nova Lei das Sociedades por Ações Comentada, V. II. Rio de Janeiro: Freitas Bastos, 1977 , p. 594.
} 
intuito resguardar a manutenção de igualdade de título ou mérito perante a Lei e evitar que uma pessoa seja julgadora de seus próprios atos.

No âmbito societário, como acima se tratou, os acionistas de uma mesma classe e espécie ocupam uma mesma posição jurídica, um mesmo status jurídico em relação à companhia. Todos são acionistas, todos realizaram investimentos em favor da companhia e todos esperam receber a devida contrapartida ao final do exercício. Todos os acionistas, ao investirem na companhia, esperam que ela realize seu objeto social, produza rendimentos e os distribua. Esse intento comum é que faz os acionistas serem iguais entre si e perante a Lei ${ }^{84}$.

Assim, conferir ou permitir tratamento diferenciado a indivíduos que compartilham uma mesma situação jurídica, sem fundamento razoável, é romper a igualdade que deve prevalecer entre todos, enquanto detentores do mesmo status jurídico. Daí uma das razões do comando da proibição de voto ao acionista nas deliberações cujo resultado puder beneficiá-lo de modo particular.

Da mesma forma, o legislador, parecendo assumir o preceito do homo economicus, que toma decisões com base na satisfação de seu interesse pessoal, considerou que o voto do acionista interessado pela aprovação de seu benefício particular apenas poderia ser tomado a seu favor. Deste modo, como já se viu, o fundamento da proibição de voto por benefício particular está assentado também no Princípio Nemo Iudex In Causa Propria, pois tem por intuito afastar os inconvenientes de uma pessoa julgar favoravelmente os próprios atos, evitando que o acionista tome partido a seu próprio favor.

Assim, no benefício particular, como se demonstrou, um dos intuitos do legislador foi regrar a matéria para não permitir que o acionista interessado vote favoravelmente a si tema que lhe diga respeito direta e exclusivamente ${ }^{85}$.

\footnotetext{
${ }^{84}$ COMPARATO, F.K. Controle Conjunto, Abuso no exercício do Voto Acionário e Alienação Indireta de Controle Empresarial In: Direito Empresarial: Estudos e Pareceres, $2^{a}$ tiragem, São Paulo: Saraiva, 1995, p. 89.

${ }^{85}$ Vide Valverde, Sociedade por Ações, Vol. II, , p. 66/67; Lopes Pontes, Sociedades Anônimas, Vol. I, 3. p. 430/431; Carvalho de Mendonça, Tratado de Direito Comercial Brasileiro, Vol. II, p. 346/349.
} 
Portanto, a razão de ser do instituto do benefício particular não é resguardar o interesse da companhia, até porque, por conceitualmente ser uma vantagem lícita, legítima, não coloca em confronto direto os interesses do acionista e da própria companhia.

Pois bem. Entendidos os fundamentos em que está assentada a proibição do exercício de voto em casos de benefício particular, fica claro que o controle de tal situação apenas pode ser realizado ex ante, a priori, anteriormente ao próprio exercício de voto do acionista.

Como se verá no capítulo seguinte, que tratará dos critérios de diferenciação entre o benefício particular e o conflito de interesses, a discussão do controle ex ante ou ex post existente para o conflito de interesses advém das características e fundamentos inerentes ao próprio instituto.

No caso do instituto do conflito de interesses, como sua ratio mais evidente, ao contrário do benefício particular, é resguardar os interesses da companhia, como se verá no próximo capítulo, pode ser fazer presente a dúvida se o acionista, no momento do voto, tomará partido em benefício próprio ou se respeitará os interesses sociais, fazendo com que doutrinadores defendam que o conflito de interesses deve ser detectado a posteriori ${ }^{86}$.

\footnotetext{
${ }^{86}$ Apesar disso, há forte corrente doutrinária que defende a apuração formal do conflito de interesses, tais como: Modesto Carvalhosa (Comentários à Lei das Sociedades Anônimas, V.II, São Paulo: Saraiva, 2003, p. 466), Waldemar Ferreira (cf. BULHOES PEDREIRAS, J.L; LAMY FILHO, A.A Lei das S.A., Renovar, 2a ed., 2o volume, pág. 239 e 240), Arnoldo Wald (A Evolução do regime legal do Conselho de Administração, os Acordos de Acionistas e os Impedimentos de Votos dos Conselheiros decorrentes de Conflitos de Interesses. Revista de Direito Bancário, do Mercado de Capitais e da Arbitragem $\mathrm{n}^{\circ} 11 \mathrm{pp}$ 13-30), Mauro Rodrigues Penteado (Aumento de Capitais nas Sociedades por Ações. Tese apresentada ao Departamento de Direito Comercail da Universidade de São Paulo para obtenção do título de Doutor em Direito, 1896, p. 264), Renato Ventura Ribeiro (Direito de Voto nas Sociedades Anônimas. São Paulo: Quatier Latin, 2009) e Rodrigo Uria (Derecho Mercantil. Madrid : Marcial Pons, 1995, p. 308).
} 
Assim, no conflito de interesses, para os defensores da tese do conflito material, o acionista poderia votar e, caso com seu voto lesasse os interesses da companhia, seria responsabilizado ${ }^{87}$.

Isso não pode ocorrer no caso do benefício particular, uma vez que, como se viu, se trata de vantagem de origem legítima, lícita, não fazendo sentido, pois, defender outro posicionamento que não o controle ex ante do benefício particular.

Até porque, como já se demonstrou, o impedimento de voto do acionista beneficiado particularmente serve para legitimar a quebra de igualdade prevista pelo $\S 1^{\circ}$ do artigo 109 da Lei n. 6.404/76, devendo, necessariamente ocorrer antes da deliberação.

Nesse sentido, pode-se citar FRANÇA: "Pode-se concluir, assim, que, na hipótese de deliberação que beneficie o acionista de modo particular, está-se também, tal como das duas primeiras hipóteses previstas no $\$ 1^{\circ}$ do art. 115 , diante de um caso de divieto de voto, sendo nulo o voto proferido em desrespeito à proibição, independentemente de qualquer indagação acerca do conteúdo da deliberação ou de eventual prejuízo, potencial ou atual, à companhia ${ }^{88}$.

Da mesma forma, COMPARATO, para quem o controle se opera ex ante "nas situações de conflito aberto de interesses, relacionadas no $\$ 1^{\circ}$ do art. 115: deliberações

\footnotetext{
${ }^{87}$ Muitos são os defensores do conflito material de interesses, dentre eles: Erasmo Valladão e Novaes França (Conflito de Interesses nas Assembléias de S.A São Paulo: Malheiros, 1993.), Trajano de Miranda Valverde (Sociedade por Ações, Vol. II, 2. ed. Rio de Janeiro: Forense, 1953, p. 69), Carlos Fulgêncio da Cunha Peixoto (Sociedades por Ações, Vol. III, São Paulo: Saraiva, 1973, p. 81), Carvalho de Mendonça (Tratado de Direito Comercial Brasileiro, v. IV. São Paulo: Freitas Bastos, 1946, p. 64), Fran Martins (Op.cit., v. II, p. 84), José Alexandre Tavares Guerreiro (Conflitos de Interesse entre Sociedade Controladora e Controlada e entre Coligadas no Exercício do Voto em Assembléias Gerais e Reuniões Sociais. Revista de Direito Mercantil, n. 51, jul-set/83, PP. 29-32) e Rodrigo Ferraz Pimenta da Cunha (Estrutura de Interesses nas Sociedades Anônimas. São Paulo, Quartier Latin, 2007, p. 282). No entanto, apesar de a Comissão de Valores Mobiliários já ter adotado entendimento a favor e contra no que se refere ao conflito material (Contra: Inquérito Administrativo CVM ${ }^{\circ}$ TA/RJ 2001/4977; A Favor: Inquérito Administrativo CVM nº TA/RJ 2002/1153), seu último entendimento é pela apuração formal do interesse conflitante (Vide Caso Tractebel Processo Administrativo nº RJ 2009-13179).

${ }^{88}$ FRANÇA, Erasmo Valladão e Novaes. Conflito de Interesses nas Assembléias de S.A. São Paulo: Malheiros, 1993, p. 90/91.
} 
relativas ao laudo de avaliação dos bens com que concorrer para a formação do capital social, aprovação das contas do votante como administrador ou concessão de vantagens pessoais. Trata-se, ao final, de mera aplicação do princípio nemo iudex in causa própria ${ }^{89}$.

A Comissão de Valores Mobiliários, nas oportunidades em que se manifestou acerca da aplicação do benefício particular, conforme se analisará em capítulo próprio, também defendeu o prévio impedimento de voto do acionista beneficiado particularmente ${ }^{90}$.

No entanto, há quem defenda a verificação substancial do benefício particular , como LEÃES. Tal autor, buscando a origem do instituto no Direito Alemão, entende que as hipóteses de divieto de voto devem ficar restritas à aprovação das contas como administrador e do laudo de avaliação de bens com que concorrer para a formação do capital social, sendo que haveria conflito de interesses "em todas as demais hipóteses em que for apurada efetiva conflituosidade, expressa em uma vantagem experimentada pelo acionista de modo particular (a lei brasileira, como se vê, repete a locução da lei alemã) ${ }^{\prime 91}$.

Para o citado autor, "trata-se de uma presunção absoluta iuris et de iure, de que, nas específicas hipóteses previstas em lei (laudo de avaliação e aprovação de suas contas como administrador), o conflito de interesses se instaura, independentemente das motivações que passam conduzir os acionistas a exercerem o seu direito de voto”, o que, em sua visão, impossibilitaria "fazer uma interpretação extensiva da disciplina da proibição de voto a hipóteses que não se afeiçoem exatamente aos tipos legais que determinam a ilegitimidade do exercício do voto em assembleia" ${ }^{, 92}$.

\footnotetext{
${ }^{89}$ COMPARATO, F.K. Controle Conjunto, Abuso no exercício do Voto Acionário e Alienação Indireta de Controle Empresarial In: Direito Empresarial: Estudos e Pareceres, $2^{a}$ tiragem, São Paulo: Saraiva, 1995, p. 91..

${ }^{90}$ Nesse sentido, cite-se o voto proferido pelo Diretor Marcelo Trindade nos autos do IA CVM n. TA/RJ 2001/4977, o voto da Diretora Norma Parente nos autos do IA CVM n. TA/RJ 2002/1153, PAS RJ 2009/13179, o próprio Parecer de Orientação CVM n. 34, de 2006, e o PAS CVM 2007/8844, que, em sede do pedido de reconsideração dos acionistas minoritários, discutiu diretamente a questão do controle a priori do benefício particular.

${ }^{91}$ LEÃES, L.G.P. de B. Proibição de Voto e Conflito de Interesses nas Assembléias Gerais. In.: Pareceres, São Paulo: Singular, 2004, p. 180.

${ }^{92}$ Ibdem, idem.
} 
Outro autor que defende a análise casuística da questão é NASCIMENTO. O autor, equiparando o instituto do benefício particular ao conflito de interesses, entende que o tratamento dado a um deve necessariamente servir ao outro, em razão da semelhança entre $\operatorname{ambos}^{93}$.

Em verdade, como acima se demonstrou, a origem do termo benefício particular, tal como utilizado hoje no Brasil, encontra-se no Direito Francês, estando de longa data positivada em nosso ordenamento jurídico, pressupondo o conceito de vantagem lícita, não havendo que se falar em conflituosidade entre o interesse do acionista e o social, o que poderia justificar o controle ex post do instituto sob o argumento de que, ao exercer o direito de voto, o acionista poderia optar por seguir interesse mais alinhado ao da companhia.

Ademais, como acima se adiantou e se verá mais detidamente no próximo capítulo, o fundamento do benefício particular é distinto daquele concernente ao conflito de interesses, guardando os institutos significativas diferenças, não comportando qualquer equiparação para tal finalidade.

Tem-se, assim, que o benefício particular é tema que pode e deve ser verificado $a$ priori, tratando-se, pois, de divieto de voto, podendo, por essa razão, ser levantado pela própria

\footnotetext{
${ }^{93}$ NASCIMENTO, J.P.B. Conflito de Interesses no Exercício do Direito de Voto nas Sociedades Anônimas (2a parte). Revista de Direito Bancário, do Mercado de Capitais, n. 25, ano 7, jul-set 2004, PP. 82-103. Na visão do referido autor: "Por outro lado, nas duas outras hipóteses previstas no art, 115, $\$ 1^{\circ}$, da Lei das S.A., as quais se referem, respectivamente, (i) às deliberações sobre matérias que puderem beneficiar o acionista de modo particular; e (ii) às deliberações em que o acionista tiver interesse conflitante com o da companhia, entendemos que não constituem hipóteses de proibição de voto, devendo-se na ocorrência dessas situações permitir que o acionista exerça seu direito de voto, aplicando-se um exame casuístico, ex post factum, sobre a nulidade do voto proferido". Justifica seu entendimento da seguinte maneira: Consideramos que a aprovação da matéria em que exista 'interesse conflitante' proporcionará para o acionista um 'benefício particular', entendemos que se relacionam intimamente os conceitos de 'benefício particular' e de 'interesse conflitante'. [...] Uma vez que os conceitos de 'interesse conflitante' e 'benefício particular' andam juntos, entendemos que, por uma questão de segurança jurídica, dever-se-ia dedicar às questões de benefício particular o mesmo cuidado dedicado às questões de conflito de interesses, devendo-se assim analisar casuisticamente as hipóteses de vedação de voto das quais poderá resultar um benefício particular. Assim sendo, nas hipóteses de benefício particular entendemos que deve ser permitido que o acionista vote, a menos que este se declare impedido, uma vez que não se pode afastar a possibilidade de o acionista, nessa situação, optar pela decisão mais alinhada ao interesse da companhia".
} 
Mesa Diretora dos trabalhos em uma assembleia, caso o acionista beneficiado não se julgar impedido 94 .

\section{$\underline{1.4 \text { - Consequências da violação à regra legal }}$}

Definidos os principais contornos do instituto do benefício particular e traçadas algumas linhas acerca de seu efeito precípuo, cumpre tratar a respeito das implicações que poderão advir caso o acionista beneficiado particularmente descumpra o comando legal insculpido no $\S^{\circ}$ do artigo 115 da Lei n. 6.404/76.

Como acima se demonstrou, o supra citado dispositivo proíbe o acionista beneficiado particularmente de participar da deliberação que irá lhe atribuir uma vantagem especial. Mas e se o acionista participar? E mais, com o seu voto, contribuir decisivamente para a aprovação da concessão da vantagem?

O artigo 115 não estabelece uma sanção ${ }^{95}$ específica ao descumprimento da norma relativa ao benefício particular, ao contrário do que ocorre nas hipóteses do conflito de interesses e do voto abusivo.

De fato, são muito claras as disposições relativas ao descumprimento do comando legal concernente ao interesse conflitante e ao voto abusivo, tal como se pode aferir da leitura dos parágrafos terceiro e quarto do mencionado artigo 115.

\footnotetext{
${ }^{94}$ FRANÇA, ao afirmar que "[...] por não cuidar a hipótese enfocada de um divieto de voto, a mesa diretora dos trabalhos na assembleia não dispõe, nesse caso, do poder de obstar o voto do acionista, ainda que o conflito transpareça a priori da própria estrutura da relação ou negócio sobre que se vai deliberar [...]", acaba por admitir, a contrario sensu, que nas hipóteses de divieto de voto a mesa diretora dos trabalhos em assembleia poderá obstar o voto do acionista impedido de votar (Conflito de Interesses nas Assembleias de S.A., p.98)

95 Como ensina KELSEN, "A ordem social pode prescrever uma determinada conduta humana sem ligar à observância ou não observância desse imperativo quaisquer consequências. Também pode, porém, estatuir uma determinada conduta humana e, simultaneamente, ligar a essa conduta a concessão de uma vantagem, de um prêmio, ou ligar à conduta oposta uma desvantagem, uma pena (no sentido amplo da palavra). O princípio que conduz a reagir a uma determinada conduta com um prêmio ou uma pena é o princípio retributivo (Vergeltung). $O$ prêmio e o castigo podem compreender-se no conceito de sanção. No entanto, usualmente, designa-se por sanção somente a pena, isto é, um mal - a privação de certos bens como a vida, a saúde, a liberdade, a honra, valores econômicos - a aplicar como consequência de uma determinada conduta, mas já não o prêmio ou a recompensa" (Teoria Pura do Direito. São Paulo: Martins, 2000, p. 26). O termo "sanção" utilizado neste trabalho refere-se à pena, ao castigo, à punição pelo descumprimento de um preceito legal.
} 
O parágrafo terceiro, atinente ao voto abusivo, prescreve que o acionista responde pelos danos causados pelo exercício abusivo do direito de voto, ainda que seu voto não haja prevalecido.

Já o parágrafo quarto, ligado ao instituto do conflito de interesses, determina que a deliberação tomada em decorrência do voto de acionista que tem interesse conflitante com o da companhia é anulável, sendo que o acionista responderá pelos danos causados e será obrigado a transferir para a companhia as vantagens que tiver auferido.

No entanto, o dispositivo em questão nada menciona sobre a consequência jurídica associada ao descumprimento da norma reservada ao benefício particular. Todavia, não é crível que o ordenamento jurídico não tenha cominado sanção específica a tal situação ${ }^{96}$.

Nesse sentido, cumpre relembrar que o voto do acionista beneficiado particularmente em deliberação que lhe concederá uma vantagem particular traduz-se como um ato contrário à lei, violador da norma que, como se sabe, proíbe tal conduta.

Aplicando, pois, a Teoria Geral das Nulidades, pode-se afirmar, de acordo com o artigo 166, inciso VII, do Código Civil, que o negócio jurídico é nulo quando a lei expressamente proíbe sua prática e não lhe comina uma sanção específica por isso ${ }^{97}$, tal como ocorre com o benefício particular.

\footnotetext{
${ }^{96}$ Como diz KELSEN, “ [...] uma ordem social pode - e este é o caso da ordem jurídica - prescrever uma determinada conduta precisamente pelo fato de ligar à conduta oposta uma desvantagem, como a privação dos bens acima referidos, ou seja, uma pena no sentido mais amplo da palavra. Desta forma, uma determinada conduta apenas pode ser considerada, no sentido dessa ordem social, como prescrita, na medida em que a conduta oposta é pressuposto de uma sanção (no sentido estrito)" (Op.cit., p. 26). E mais: "O sentido do ordenamento traduz-se pela afirmação de que, na hipótese de uma determinada conduta - quaisquer que sejam os motivos que efetivamente a determinaram - deve ser aplicada uma sanção (no sentido amplo de prêmio ou pena) (Op.cit. p. 28).Por fim: "Uma outra característica comum às ordens sociais a que chamamos Direito é que elas são ordens coativas, no sentido de que reagem contra situações consideradas indesejáveis, por serem socialmente perniciosas - particularmente contra condutas humanas indesejáveis - com um ato de coação, isto é, com um mal - como a privação da vida, da saúde, da liberdade, de bens econômicos e outros [...]" (Op.cit. p. $35)$.

97 “Art. 166. É nulo o negócio jurídico quando:

I - celebrado por pessoa absolutamente incapaz;
} 
A nulidade pode ser entendida como a sanção ${ }^{98}$, imposta pela norma jurídica, que determina a privação dos efeitos jurídicos do ato negocial praticado em desobediência ao que a lei prescreve $\mathrm{e}^{99}$. Para GOMES, a nulidade absoluta possui algumas características próprias, tais como o caráter imediato (invalida o negócio desde sua formação), absoluto (pode ser alegado por qualquer interessado e pronunciada de ofício pelo juiz), incurável (as partes não podem saná-la nem o juiz supri-la) e perpétuo (não se convalida pelo decurso de tempo) ${ }^{100}$.

Entretanto, o artigo 286 da Lei n. 6.404/76, ao prescrever que a ação para anular as deliberações tomadas em assembleia geral ou especial, irregularmente convocada ou instalada, violadoras da lei ou do estatuto, ou eivadas de erro, dolo, fraude ou simulação, prescreve em 2 (dois) anos, contados da deliberação, positiva o regime das anulabilidades no que se refere aos atos jurídicos assembleares praticados no âmbito das companhias ${ }^{101}$.

O regime da anulabilidade (ou nulidade relativa), segundo a doutrina, "prende-se a uma desconformidade que a norma considera menos grave, uma vez que o negócio anulável viola preceito concernente a interesses meramente individuais, acarretando uma reação

II - for ilícito, impossível ou indeterminado seu objeto;

III - o motivo determinante, comum a ambas as partes, for ilícito;

$I V$ - não revestir a forma prescrita em lei;

$V$-for preterida alguma solenidade que a lei considere essencial para sua validade;

VI-tiver por objetivo fraudar lei imperativa;

VII - a lei taxativamente o declarar nulo, ou proibir-lhe a prática, sem cominar sanção."

${ }^{98}$ Segundo as lições de KELSEN, aqui entendida como uma pena, um mal.

${ }^{99}$ FIUZA, R. Novo Código Civil Comentado, $5^{\mathrm{a}}$ ed. São Paulo: Saraiva, 2006, p. 145.

${ }^{100}$ GOMES, O. Introdução ao Código Civil, $12^{\mathrm{a}}$ ed. Rio de Janeiro: Forense, 1996, p.474.

${ }^{101}$ A esse respeito, LAMY FILHO, um dos autores do anteprojeto que veio a se converter na atual Lei das Sociedades por Ações, assim se pronunciou: "[...] no âmbito do direito societário não tem aplicação irrestrita o regime das nulidades do direito civil, regida pelo princípio 'quod nullum est, nullum producit effectum': como sustenta Trajano Valverde (S.A., v. III, n. 811, p.94), 'não seria possivel, realmente, ainda que nula ab origine, dizer-se que uma sociedade, como sujeito de direito, nunca existiu ou se como nunca tivesse existido'. Pontes de Miranda (1954-1969, t.51, p. 106), embora oponha restrições a Trajano, afirma: 'O princípio em que se assentou a doutrina contemporânea, diante da política protetiva dos interesses de terceiros, foi o princípio de eliminação da causa de invalidade ou princípio da sanação, se, pela natureza da causa, é ela eliminável'.[...] Ouça-se, a propósito, Trajano Valverde (comentando texto semelhante ao vigente): 'A assembleia geral pode sempre rever suas próprias deliberações. Pode assim cancelar ou anular deliberação anterior e ratificar todos os atos que interessem à sociedade" (cf. parecer "Acordo de Acionistas dobre Exercício de Direito de Voto". In.: A Lei das S.A. Rio de Janeiro: Renovar, 1992, p. 545-546). 
menos extrema"102. Assim, ao contrário do ato nulo, a invalidação do ato anulável gera efeitos ex nunc, produzindo efeitos até o momento da invalidação, respeitando-se os gerados anteriormente, podendo ser provocada somente pelo prejudicado com o negócio ou seus representantes legítimos, não se pronunciando ex officio pelo juiz ${ }^{103}$. O ato anulável pode ser sanado pelas partes ${ }^{104}$ e sobre ele opera-se a decadência ${ }^{105}$.

O regime das anulabilidades adotado pela Lei n. 6.404/76 já era previsto em sua essência pelo Decreto-lei n. 2.627/40, sendo fruto de construções doutrinárias da época, tais como MIRANDA VALVERDE e CARVALHO DE MENDONÇA, que criticavam o regime das nulidades previsto na norma anterior, o Decreto n. 434 de 1891, que fundamentado na Lei n. 3.150 de 1882 , consolidou a legislação societária brasileira ${ }^{106}$.

No entanto, posteriormente, a doutrina passou a indagar se o fato de a Lei $\mathrm{n}$. 6.404/76 ter adotado o regime das anulabilidades implicava no afastamento absoluto do regime comum das nulidades ${ }^{107}$.

${ }^{102}$ FIUZA, R. Op.cit. p. 154.

${ }^{103}$ Vide art. 177 do Código Civil.

${ }^{104}$ Art. 172 do Código Civil.

${ }^{105}$ Art. 178 e 179 do Código Civil.

${ }^{106}$ FRANÇA, em sua obra sobre o tema, citando os referidos doutrinadores, bem como Pontes de Miranda, descreve como se deu as discussões que levaram a adoção pela legislação societária do regime das anulabilidades no que se refere aos atos assembleares. A partir da análise de sua obra observa-se que Carvalho de Mendonça defendia que aplicar o regime das nulidades aos atos assembleares seria prestigiar a fraude, na medida em que se poderia constituir a sociedade, se praticar atos e negócios jurídicos e, mais tarde, se declarar tudo inválido $a b$ initio por uma simples falta de firma no instrumento de constituição social, ferindo mais os inocentes do que os culpados. Foi então que em prol do Princípio da Continuidade da Empresa, Miranda Valverde, autor do anteprojeto que viria se converter no Decreto-lei n. 2.627/40, acatou os entendimentos de Carvalho de Mendonça, expressando que "o regime comum das nulidades dos atos jurídicos não se ajusta, sem graves distorções, aos organismos que, sob a denominação de sociedades, associações, corporações, fundações, surgem por obra das energias dos homens e atuam, como sujeitos de direito, na vida social", mesmo sob as críticas de Pontes de Miranda, que defendia a existência de atos nulos e inexistentes no âmbito das sociedades por ações (Invalidade das Deliberações de Assembleias das S.A. São Paulo: Malheiros, 1996, p.15 e ss).

107 Nesse sentido, vale transcrever o posicionamento de FRANÇA: "À vista, pois, do inegável interesse relacionado a um maior grau de certeza e segurança na eficácia das deliberações, é de indagar se o legislador, ao criar um regime especial de invalidade destas, estabelecendo um prazo de prescrição brevi temporis para a propositura da 'ação para anular as deliberações...violadoras da lei ou do estatuto', teria com isso afastado a possibilidade de aplicação do regime comum às deliberações nulas" (Invalidade das Deliberações de Assembleias das S.A. São Paulo: Malheiros, 1996, p.72). 
Nesse sentido, FRANÇA defende que a atual legislação das sociedades anônimas não excluiu, por completo, o regime das nulidades, pois, do contrário, verdadeiros absurdos poderiam ser convalidados pelo tempo, como, por exemplo, a possibilidade de se modificar os estatutos de uma sociedade de economia mista para excluir a obrigatoriedade de conselho de administração, violando a regra do artigo 239 da Lei n. $6.404 / 76^{108}$.

Assim, o mesmo autor, ao tratar sobre as diversas formas de vícios que podem recair sobre uma assembleia, quais sejam, vícios da própria assembleia (procedimentais), vícios de deliberação e vícios de voto ${ }^{109}$, defende que o regime das nulidades continua vigente para certas espécies de vícios de deliberação, tais como nas hipóteses de deliberações violadoras da ordem pública ${ }^{110}$ e da lei ${ }^{111}$, sobretudo das disposições legais que têm por objeto a proteção de interesse de terceiros ${ }^{112}$, bem como as que visam assegurar a veracidade das demonstrações financeiras ${ }^{113}$.

Em tais hipóteses o regime da nulidade se justificaria pelo caráter extrassocial dos efeitos oriundos de uma deliberação dessa natureza, que extrapolaria o mero interesse privado dos acionistas ${ }^{114}$.

Para as demais espécies de vícios, como os vícios procedimentais de assembleia e os vícios de voto, FRANÇA defende que a eles se aplica o regime da anulabilidade, por envolver apenas interesses privados dos acionistas ${ }^{115}$.

\footnotetext{
${ }^{108}$ FRANÇA, E.V. e N. Op.cit., p. 73. nota de rodapé n. 47).

${ }^{110}$ FRANÇA, E.V. e N. Op.cit.,p. 110.

${ }^{111}$ Ibdem, idem, p. 105.

${ }^{112}$ Ibdem, idem, p. 107.

${ }^{113}$ Ibdem, idem, p. 108.

${ }^{114}$ Ibdem, idem, p.115.
}

${ }^{109}$ FRANÇA adverte em sua obra sobre o tema que a classificação proposta "deveu-se muito mais ao intuito de examinar o assunto em face dos dizeres da nossa lei (art. 286) do que a um critério que se pretenda exatamente científico". O autor também esclarece que outras propostas de classificação dos vícios assembleares são utilizadas pela doutrina, como em Ascarelli e Lobo Xavier. Em ambos os casos, os vícios são classificados, em essência, em vícios de procedimento e vícios de conteúdo. Na proposta de França, os vícios de procedimento seriam equivalentes aos vícios da própria assembleia, ou seja, aqueles inerentes à própria constituição da assembleia, como irregularidade na convocação ou na instalação do conclave. Os vícios de conteúdo, na visão de França, se desdobrariam entre vícios de deliberação, isto é, vícios que dizem respeito às próprias deliberações assembleares, que podem ter violado a lei ou o estatuto social, e vícios de voto, os quais poderão estar eivados de erro, dolo, fraude ou simulação ou, ainda, terem sido proferidos em contrariedade com a lei. (Op.cit., p. 85-86, incluindo 
Dentro da classificação dos vícios de assembleia proposta pelo referido autor, a violação à regra do benefício particular enquadrar-se-ia como vício de voto, pois a irregularidade, neste caso, está no próprio voto proferido pelo acionista beneficiado particularmente, que, de acordo com o artigo $115, \S 1^{\circ}$, da Lei n. $6.404 / 76$, não poderia ter sido proferido. Importante observar, todavia, que, nos casos de vícios de voto, a deliberação apenas deverá ser invalidade se o voto tiver sido decisivo para o seu resultado ${ }^{116}$.

Deste modo, considerando que o acionista beneficiado particularmente tenha exercido o seu voto na assembleia que deliberou a respeito da concessão das vantagens e, com seu voto, formou a maioria necessária para a aprovação da concessão dos benefícios, a deliberação poderá ser anulada, na forma prevista pelo artigo 286 da Lei n. 6.404/76. Nesse caso, a anulação da deliberação assemblear obrigará o acionista a devolver à companhia todas as vantagens especiais que tiver auferido.

Se o voto do acionista beneficiado particularmente não tiver interferido no resultado da deliberação, não haverá qualquer sanção, muito embora o voto, em si, seja nulo de pleno direito, pois violador de norma legal. Com efeito, como o benefício particular não pressupõe o ilícito e o dano à companhia ou a outros acionistas, tal como se demonstrou no início deste capítulo, não há razão para se falar em responsabilização nessa hipótese, ao contrário do que ocorre com o voto abusivo (art. 115, §3º da Lei n. 6.404/76).

\footnotetext{
${ }^{115}$ Ibdem, idem, p.116.

${ }^{116}$ Ibdem, idem, p.113-114.
} 


\section{II - O CONFLITO DE INTERESSES E O BENEFÍCIO PARTICULAR: INSTITUTOS DISTINTOS ENTRE SI}

Tal como no caso do benefício particular, o instituto do conflito de interesses no âmbito da assembléia geral de acionistas está previsto no artigo $115, \S^{\circ}$, da Lei $n^{\circ} 6.404 / 76$, o qual prescreve que o acionista não poderá votar nas deliberações da assembléia-geral relativas ao laudo de avaliação de bens com que concorrer para a formação do capital social e à aprovação de suas contas como administrador, nem em quaisquer outras que puderem beneficiá-lo de modo particular, ou em que tiver interesse conflitante com o da companhia.

Como se sabe, o dispositivo em tela, além de definir especificamente duas situações em que ocorrerá o impedimento do exercício do direito de voto do acionista (aprovação de laudo de avaliação em que concorrer para a formação do capital social e aprovação de suas contas como administrador), ainda o admite, genericamente, em duas outras circunstâncias principais: no caso da concretização do conflito de interesses e/ou da configuração do benefício particular.

As duas primeiras hipóteses previstas não ensejam maiores discussões doutrinárias ou jurisprudenciais a respeito, apresentando-se como situações bastante objetivas, de fácil aplicação para o intérprete.

O mesmo, contudo, não pode ser dito em relação às duas hipóteses genéricas previstas pela norma. A experiência tem demonstrado que os aplicadores do direito têm certa dificuldade em estabelecer uma linha de demarcação para precisar os limites de aplicação de um instituto e do outro.

A própria Comissão de Valores Mobiliários reconhece tal dificuldade, ao expressar que "não há um critério objetivo unânime que distinga hipóteses 'que puderem beneficiar [o acionista] de modo particular e hipóteses em que o 'interesse [do acionista seja] conflitante 
com o da companhia' ( $\$ 1^{\circ}$ do art. 115), [sendo] normalmente difícil distinguir as hipóteses de benefício particular das hipóteses de conflito de interesses" ${ }^{\prime 117}$.

Mas realmente não há um critério que possa diferenciar ambos os institutos? Para responder essa pergunta faz-se necessário realizar uma breve análise do próprio instituto do conflito de interesses.

\section{$\underline{2.1 \text { - O Conflito de Interesses nas Assembléias Gerais de Acionistas }}$}

A palavra conflito, utilizando-se, primeiramente, da lição dos léxicos, indica, necessariamente, uma contraposição, um choque, um embate entre duas situações. De acordo com o Dicionário Houaiss da Língua Portuguesa, o termo conflito pode ser definido como o ato, estado ou efeito de divergirem acentuadamente ou de oporem duas ou mais coisas.

Portanto, semanticamente, quando se fala em conflito de interesses há que se pressupor a existência de dois interesses distintos e contrapostos entre si, interesses que se conflitam entre si.

Juridicamente, a questão dos interesses e seus conflitos foi estudada por CARNELUTTI na primeira metade do século XX. O mestre italiano ensina que o conceito de interesse está atrelado às relações de caráter econômico existentes entre as pessoas e os objetos existentes no mundo fático.

Vale dizer, as pessoas possuem necessidades a serem satisfeitas e os bens, em verdade, são os objetos que podem satisfazer tais necessidades. O interesse, assim, nasce da necessidade das pessoas em possuir aqueles bens que possam satisfazê-la. Assim, interesse seria a relação jurídica entre um indivíduo, que possui uma necessidade, e o bem apto a satisfazê-la ${ }^{118}$.

\footnotetext{
${ }^{117}$ Parecer de Orientação CVM no 35 , de 18 de agosto de 2006.

${ }^{118}$ CARNELUTTI, F. Teoria Geral do Direito (trad. A. Rodrigues Queiroz e Artur Anselmo de Castro. Rio de Janeiro, 2006, p. 86. No mesmo sentido pode ser apontado JAEGER: "Per interesse intendiamo la relazione tra
} 
De um modo geral, como as pessoas costumam ter interesses diversos, tais interesses poderão interagir entre si, podendo tal interação assumir um aspecto de indiferença ou relevância. Indiferença ocorrerá quando um interesse pode ser satisfeito sem implicar em efeitos aos interesses dos demais envolvidos. Relevância, pelo contrário, quando a satisfação de um interesse pode implicar em efeitos em relação aos interesses de qualquer outro ${ }^{119}$.

As interações de relevância, por sua vez, se agrupam em situações de solidariedade ou de conflito. Solidariedade haverá quando a satisfação de um interesse contribuir para a satisfação de outro. Neste caso, a colaboração das pessoas interessadas cria condições para a satisfação da necessidade de todos os envolvidos, o que seria mais difícil de ocorrer se cada um buscasse o seu próprio interesse $\mathrm{e}^{120}$.

Interessante notar como a solidariedade de interesses enseja o surgimento daquilo que se denomina interesse coletivo, isto é, a união dos interesses convergentes e solidários de dois ou mais indivíduos na realização de um fim comum ${ }^{121}$. É o interesse coletivo, ou seja, a vontade plural em satisfazer determinada necessidade comum, que move duas ou mais pessoas a se associarem na busca de um mesmo objetivo.

As situações de conflito, por outro lado, são relacionadas à escassez natural dos bens econômicos ${ }^{122}$, sendo comum ocorrer situações nas quais a satisfação de um interesse só

\footnotetext{
um soggetto, cui fa capo um bisogno, e Il bene idoneo a soddisfare tale bisogno, determinata nella previsione generale ed astratta di uma norma" (L'Interesse Sociale, Milano: Giuffré, 1972, p. 3).

${ }_{119}$ JAEGER, P.G. L'Interesse Sociale, Milano: Giuffré, 1972, p. 7.

${ }^{120}$ CARNELUTTI, F. Op.cit. p. 88. Segundo o autor se um homem não comeu e, assim, não restaurou suas forças, não consegue construir a sua casa. A satisfação das necessidades nesse caso, diz ele, não ocorre senão através de conquistas de patamares gradativos, ou seja, para comer, o homem deve primeiro procurar o alimento, e, para construir a casa, fortalecido com a refeição, deve sair para procurar os materiais. Há, deste modo, uma relação de instrumentalidade entre os interesses da mesma pessoa, na medida em que um possibilita atingir o outro, assim sucessivamente.Vide também JAEGER, op.cit., p. 8.

${ }^{121} \mathrm{Na}$ visão de JAEGER: "In termine interesse coletivo non esprime altro que questa solidarietà di interesse, nella quale si può ritrovare la spiegazione di ogni manifestazione della vita giuridica, dai negozi alle forme associative, più semplice e via via sempre piu complesse, fino a quelle che abbraciano tutti $i$ citadini (ordinamento statuale) o addirittura (ordinamento internazionale) l'umanità intera" (Op.cit. p. 9).

${ }^{122}$ NUSDEO, F. Curso de Economia - Introdução ao Estudo do Direito Econômico. $2^{\mathrm{a}}$ Ed. São Paulo: RT, 2000, p. 28.
} 
possa se dar com o sacrifício de outro ${ }^{123}$. Nas situações de interesses conflitantes, o bem pretendido por dois ou mais interessados não é capaz de satisfazer a necessidade de todos, gerando embate, disputa, ${ }^{124}$ onde, ao final, apenas uma relação de interesse será satisfeita, em detrimento das demais, as quais restarão prejudicadas.

Destarte, percebe-se que o conflito de interesses pressupõe o prejuízo, o dano, a perda a alguns daqueles que estão envolvidos no embate, na medida em que, na disputa sobre o bem pretendido, que não pode satisfazer a todos, apenas um ou alguns serão satisfeitos, enquanto outros não. Por essa razão, por implicar na interferência na esfera de direito alheia, relações intersubjetivas de conflitos de interesses possuem relevância jurídica, merecendo ser tutelada pelo Direito.

Societariamente, o conflito de interesses, como se sabe, encontra-se regulado, no ordenamento jurídico pátrio pelo artigo $115, \S^{\circ}$, da Lei $\mathrm{n}^{\circ} 6.404 / 76$, pressupondo, necessariamente, a idéia de um interesse que, ao menos potencialmente, não poderá ser satisfeito sem o mínimo sacrifício de um outro. Tratando sobre a questão, no âmbito societário, está GALGANO e GENGHINI ${ }^{125}$ :

"C'è conflitto di interesse fra sócio e società quando il sócio si trova nella condizioni di essere portatore, di fronte ad uma diliberazione, di um dúplice interesse:Del suo interesse di sócio e, inoltre, di um interesse esterno alla società; e questa duplicità di interesse è tale, per cui egli non può realizare l'uno se non sacrificando l'altro interesse . La semplice duplicità della posizione di interesse in capo ad um messimo soggetto di per sé sola non implica, però, situazione di conflitto in senso tecnico"

\footnotetext{
123 CARNELUTTI, F. Op.cit. p. 88. Nas palavras de FRANÇA: "Quando, porém, a satisfação de uma necessidade exclui a de outras, dá-se, então, o conflito, que é a conseqüência da limitação dos bens, em confronto com as necessidades do homem. Por essa razão, disse Carnelutti, freqüentemente o homem se coloca em um dilema: qual necessidade deve ser satisfeita e qual sacrificada? Assim se delineia o conflito entre dois interesses da mesma pessoa" (Op. Cit. p. 17).

${ }^{124}$ JAEGER, P.G. L'Interesse Sociale, Milano: Giuffré, 1972, p. 8.

${ }^{125}$ GALGANO, F.; GENGHINI, R. Il Nuovo Diritto Societario: Le nouve società di capitalli e cooperative, tomo I, Milão: CEDAM, 2006, p. 400.
} 
Os autores italianos, ao mencionarem a duplicidade de interesses que pode ensejar o conflito, mencionam a existência de um interesse como sócio e de um interesse externo ao social. O conflito no âmbito societário, assim, é o choque, o embate entre o interesse do acionista como sócio e o interesse extrassocial, os quais serão tratados a seguir.

\section{$\underline{2.1 .1-O ~ I n t e r e s s e ~ S o c i a l ~}$}

$\mathrm{O}$ artigo $115, \S 1^{\circ}$, da Lei $\mathrm{n}^{\circ} 6.404 / 76$ determina que o acionista não poderá votar nas deliberações em que tiver interesse conflitante com o da companhia. Mas em que consiste o interesse da companhia ou o interesse social?

Há tempos o interesse social é objeto de profundos estudos e acirrados debates no âmbito da doutrina nacional e internacional. Em linhas gerais, os estudiosos do tema dividemse em duas vertentes de idéias e opiniões acerca da natureza do interesse social, dando origem as chamadas escolas contratualistas e institucionalistas.

As correntes doutrinárias contratualistas foram construídas a partir da essência da Teoria Agregacionista de IHERING ${ }^{126}$, sendo fundadas, por conseguinte, na concepção de que as companhias são constituídas por um acordo de vontades entre os vários sócios que a compõe. Assim sendo, o interesse social não seria mais do que o interesse comum dos sócios.

\footnotetext{
126 A Teoria Agregacionista, iniciada no final do século XIX e fundada em princípios liberais, defendia que a associação de indivíduos surge com a agregação de seus membros, que, tendo um fim, comum, reúnem-se com um propósito específico. Deste modo, o caráter privado, consubstanciado na livre associação dos indivíduos, é a essência de tal teoria. De acordo com tal teoria, por ser oriunda de um acordo múltiplo de vontades, a vontade da pessoa jurídica é vista como mera representação da soma das vontades de seus membros.Segundo o entendimento do próprio IHERING, "in the association, the movement of persons and things which participate in it is a converging nature; they all steer toward the same goal; the goal as well as the way is the same;the final gain is a common one" (IHERING, R. Law as a Means to na End. Boston: The Boston G.C., 1913, p. 157). Deste modo, ainda segundo o jurista alemão, nas sociedades, os interesses de todos devem ser comuns, pois que se um ganhar, todos ganham e se um perder, todos perdem: "O interesse de um amolda-se ao interesse do outro: a vantagem dele é a minha vantagem; a minha vantagem é a vantagem dele. Se as sociedades são criadas para fazer frente a um propósito específico, a solidariedade de interesses entre as partes acaba se constituindo como a pedra basilar da questão. Assim, aquele que utiliza a sociedade para atingir seus objetivos particulares, em detrimento dos objetivos comuns, afronta a idéia fundamental de toda instituição" (Op.cit. p. 220).
} 
De acordo com as escolas contratualistas, sendo a sociedade anônima formada por um acordo firmado entre seus sócios, o interesse social não poderia ir além do interesse comunitário dos próprios sócios. Vale dizer, o interesse social não seria mais do que a convergência dos interesses dos sócios de, conjuntamente, buscar um objetivo comum.

De fato, quando da constituição da sociedade, os sócios buscaram unir esforços para satisfazer uma necessidade que, isoladamente, não teriam condições. Deste modo, o fim da sociedade ou o interesse social não poderia ser outro que não a busca do objetivo comum que ensejou sua constituição.

O interesse social, então, coincidiria com o interesse comum dos sócios que motivou a constituição da própria sociedade. Seria, assim, o interesse do sócio enquanto sócio, enquanto membro de uma comunidade que visa à satisfação do interesse compartilhado por todos os demais. Nesse sentido, emblemática é a lição de ASCARELLI ${ }^{127}$ :

"Le società constituiscono indubbiamente communioni voluntarie di interessi [...]. Le società constituiscono non solo delle communioni di interesse, ma, dià pela fatto di essere voluntarie, delle communioni di scopo, nè qui interessa la più precisa delimitazioni di questo scopo in confronti di quello delle associazioni; $\grave{e}$ appunto atraverso la constituizione contrattuale di uma communioni di scopo che si constituisce la communioni di interesse.

[...]

Non mi sembra perciò che nel nostro sistema si possa far capo a um interesse sociale inteso come distinto dall'interesse commune dei soci e come tale tutelato.

Assim sendo, nas palavras de FRANÇA, "todos os outros interesses dos sócios, que não este interesse comum, típico e específico, são considerados, pois, estranhos à sociedade ou 'extra-sociais',128.

Entretanto, vale destacar que as escolas contratualistas estavam baseadas em variadas correntes de pensamento. Uma delas, derivada da corrente prevalecente exposta acima, admite que o interesse comum dos sócios, típico e específico e realizado ex causa

\footnotetext{
${ }^{127}$ ASCARELLI, T. Studi in Tema di Società. Milão: Giuffrè, 1952, p. 148 e 163.

${ }^{128}$ FRANÇA, op.cit. p.37.
} 
societatis, deve abranger não somente o interesse dos sócios atuais, mas tanto o interesse dos sócios futuros que um dia ingressarão na sociedade, como também o interesse dos sócios não somente no momento presente, mas ao longo do tempo ${ }^{129}$.

Outra corrente contratualista que merece destaque é aquele que define o interesse comum dos sócios como um conceito relativo. Assim, segunda essa escola, o interesse comum dos sócios não passa de um conceito objetivo e abstrato, que não coincide com o somatório dos interesses individuais dos sócios. Em verdade, segundo essa corrente, a comunhão de interesses individuais dos sócios seria um ponto de partida para se chegar ao interesse social $^{130}$.

Segundo JAEGER ${ }^{131}$, muito tênue seria a diferença entre a corrente afirmada acima e aquele que entende o interesse social como qualquer conjunto solidário de interesses individuais dos sócios.

Pata os adeptos dessa última doutrina, o interesse do acionista a ser levado em conta não seria apenas aquele típico e específico e ex causa societatis, mas todo e qualquer interesse que encontre aceitação entre a comunidade acionária ${ }^{132}$, não havendo, assim, uma

\footnotetext{
${ }^{129}$ Tal corrente de pensamento é defendida por ASQUINI, na obra I Battelli Del Reno, para quem "l'interesse sociale deve tener conto della variabilità dei soci nel tempo [...] e comumque dell'interesse anche non attuale, perchè a lungo termine, dei soci attuali” (cf. Jaeger, op.cit. p. 88). Para tal corrente, o interesse social, abrangendo o interesse comum ex causa societatis do sócio atual e futuro coincidiria com a própria maximização e eficiência da empresa. No entanto, tal corrente recebeu algumas críticas: "Appare infatti difficile configurari um interesse autonomo dei soci 'futuri' o 'eventuali', quando si dimostra che gli azionisti attuali hanno il potere assoluto e incondizionato di decidere se vi saranno dei soci futuri” (cf. Jaeger, op.cit. p. 167).

130 MENGONI, L. Appunti per uma revisione della teoria sul conflitto di interessi nelle deliberazioni di assemblea della società per azioni. Rivista Delle Società, ano I, 1956, p. 443. Referido autor italiano assim tratou do tema: "L'interesse sociale, si è detto, è commune in senso obbiettivo e astratto, intendendosi con ciò che l'interesse commune non è la soma degli interessi individuali dei singoli soci. Ma resta pur vero que sono próprio questi interessi concreti il punto di partenza per determinazione dell'interesse sociale, che è perciò um concetto essenzialmente relativo, incuanto risulta di uma valutazione oggetiva degli interesse particulare di cui sono portatori, in um datto momento, coloro che participano alla società".

${ }^{131}$ JAEGER, P.G. L'interesse Sociale. Milão: Giuffrè, 1972, p. 94-95.

${ }^{132}$ Nesse sentido, cite-se BERGIER, para quem “Em tout cas, l'intérêt social n'est qu'un reflet et une resultante de l'intérêt dês actionnaires" (L'abus de majorité dans lês sociètès anonymes apud Jaeger, op.cit. p. 95).
} 
diferenciação entre interesse social e extra-social, excluindo hipóteses de interesses conflitantes entre acionista e sociedade ${ }^{133}$.

Mencionadas as principais escolas contratualistas, mister se faz traçar algumas linhas acerca das correntes institucionalistas.

Uma das principais correntes de pensamento fundadas na idéia de instituição foi a criada por Walter Rathenau, empresário, filósofo e político alemão que, em 1917, publicou trabalho denominado Von Aktienwesen (Eine geschaeftiliche Betrachtung), criando a corrente doutrinária conhecida como Teoria da Empresa em Si (Unternehmen an sich) ${ }^{134}$.

A essência da Teoria de Rathenau está centrada na conceituação da sociedade anônima como uma organização voltada ao interesse público, haja vista que, ao movimentar a economia de um Estado, a atuação da empresa passa a interessar não apenas aos sócios, mas também a outros agentes que com ela se relacionam, como trabalhadores, fornecedores, governo, etc ${ }^{135 .}$

A Teoria da Unternehmen an sich contribuiu para o reconhecimento de um interesse próprio da empresa, "dirigido não à produção de lucros a serem distribuídos, mas à melhor eficiência produtiva da própria empresa", não necessariamente coincidente, pois, com o interesse comum dos sócios ${ }^{136}$.

Por outro lado, outra importante corrente institucionalista é a Teoria da Sociedade em Si (Person an sich). A Teoria da Person an sich é centrada no interesse da própria

\footnotetext{
${ }^{133}$ Jaeger, op.cit. p. 95.

${ }^{134}$ Referida teoria foi recepcionada pela Lei Acionária Alemã de 1937 (Aktiengesetz), tal como demonstra seu artigo 70, que pregava o dever dos administradores em dirigir a empresa em prol dos interesses do estabelecimento, de seus empregados, da Nação e do Reich, norma que deu origem ao chamado Führerprinzip, consubstanciado da independência da administração em relação à assembléia de sócios.

${ }^{135}$ FRANÇA, op.cit. p. 22.

${ }^{136}$ Ibdem, idem, p. 24.
} 
sociedade, o qual consiste em "um interesse próprio, que não coincide com o interesse particular dos sócios e que se sobrepõe" $"$ "137.

De acordo com COMPARATO, com a Teoria da Person an sich, "a sociedade perde a sua natureza contratual, para se apresentar como um ente autônomo, que os sócios se limitam a criar e instituir por um ato jurídico coletivo."138

Destarte, o acionista é visto como um órgão da sociedade que, no exercício do direito de voto, busca não o próprio interesse, mas o da sociedade. Fundamenta-se na concepção de que a companhia é incapaz de, per si, demonstrar sua vontade, o que, por um expediente de técnica jurídica, presume-se que a vontade declarada das pessoas físicas componentes de seu órgão deliberativo seja a própria vontade social ${ }^{139}$.

À semelhança da Teoria da Unternehmen an sich, a Teoria da Person an sich também contribuiu para consolidar a idéia de que a sociedade possui um interesse autônomo e distinto dos interesses dos sócios que nela figuram, tornando mais forte a idéia de que os sócios, nas deliberações societárias, devem perseguir os interesses sociais e não seus próprios interesses.

Outra escola institucionalista que merece ser lembrada é a Teoria da Empresa Acionária. Tal teoria, criada por Hausmann, conforme ensina LEÃES, reconhece, "na própria empresa, uma composição dos interesses das várias pessoas que delam participam (Schultz dês Unternehmens in Sinne eines Ausgleichs aller beteiligten interessen)" ${ }^{\prime 140}$. Tal teoria não afirmava que a sociedade, enquanto empresa, possuiria interesses próprios, mas reconhecia o seu caráter público, considerando como interesses merecedores de tutela não somente o interesse comum dos sócios, mas também a solidariedade de interesses de todos aqueles que com a sociedade de relacionam.

\footnotetext{
${ }^{137}$ CARVAlHOSA, M. Comentários à Lei das Sociedades Anônimas, V. II. São Paulo: Saraiva, 2009, p. 451.

${ }^{138}$ COMPARATO, F.K. Aspectos Jurídicos da Macro Empresa. São Paulo, RT, 1970, p. 45.

${ }^{139}$ Ibdem, idem, p. 454.

${ }^{140}$ LEAES, L.G.P.B. C. Conflito de Interesses.In.:Estudos e Pareceres sobre Sociedades Anônimas. São Paulo: RT, 1989, p.21.
} 
Por mais que a legislação brasileira pareça ter assimilado alguns conceitos trazidos pelas escolas institucionalistas ${ }^{141}$, a doutrina nacional sempre prestigiou o pensamento dos contratualistas, tendo sido interpretado majoritariamente o interesse social previsto no $\S 1^{\circ}$ do artigo 115 da Lei 6.404/76 como o interesse comum dos sócios enquanto sócios ${ }^{142}$.

E de fato, quando se fala em interesses, relembrando-se das lições de CARNELUTTI, está se referindo à relação entre um determinado sujeito que possui necessidades e o objeto apto a satisfazê-las. Assim, no âmbito dos fatos jurídicos, quem mais poderia ter uma necessidade e um interesse em satisfazê-la, se não o homem? Nas palavras de SENA “il concetto di interesse rappresenta um momento, um atteggiamento dell'uomo; ̀̀ infatti um concetto desunto dalla realità naturale e non può essere innestato su astrazioni giuridico-economiche quali appunto il concetto di impresa" ${ }^{143}$.

Se é o homem quem decide conjugar esforços para a realização de um fim comum, o qual, isoladamente não seria capaz de alcançar, o termo interesse social só pode significar a comunhão dos interesses de cada sócio ao se associar. O interesse social, assim, personifica a própria comunhão dos interesses individuais de cada sócio, solidários entre si na obtenção do bem comum, a qual motivou a constituição da sociedade.

Em outras palavras, o interesse social representa o interesse coletivo de todos os sócios enquanto sócios. Entretanto, muito embora pareça fazer sentido o pensamento das

\footnotetext{
${ }^{141} \mathrm{O}$ artigo 116, parágrafo único, da Lei 6.404/76 é sempre lembrado nesse sentido: " $O$ acionista controlador deve usar o poder com o fim de fazer a companhia realizar o seu objeto e cumprir sua função social, e tem deveres e responsabilidades para com os demais acionistas da empresa, os que nela trabalham e para com a comunidade em que atua, cujos direitos e interesses deve lealmente respeitar e atender". Cite-se também Salomão (O Novo Direito Societário, $4^{\mathrm{a}}$ Ed. São Paulo, Malheiros, 2011, p. 38-39).

${ }^{142}$ Pode-se mencionar nesse sentido COMPARATO (O Poder de Controle nas Sociedades Anônimas, $5^{\mathrm{a}}$ Ed. Rio de Janeiro: Forense, 2008, p. 385), BULGARELLI (Sociedades Comerciais, 2.ed, São Paulo: Atlas, 1985, p. 34/36), CARVALHOSA (Comentários à Lei de S/A, vol. II, São Paulo: Saraiva, 2009, p. 455). Importante destacar nesse ponto a visão de SALOMÃO FILHO, que propõe uma terceira linha de pensamento para conceituar o interesse social, baseada na Teoria da Organização, segundo a qual o interesse social estaria identificado com a estruturação e organização mais apta a solucionar os conflitos derivados do feixe de contratos e relações jurídicas em que se baseia a sociedade (O Novo Direito Societário, $4^{\mathrm{a}}$ Ed. São Paulo, Malheiros, 2011 p. 45).
}

${ }^{143}$ SENA, G. Il Voto nella Assemblea della Società per Azioni: Parte generale. Milão: Giuffrè, 1958, p. 122. 
correntes contratualistas, sobretudo aquela defendida por ASCARELLI, a depender do ângulo que se analise, tanto as escolas contratualistas como institucionalistas podem levar, em termos pragmáticos, a um mesmo resultado.

Com efeito, comparando as várias correntes de pensamento expostas pelas escolas contratualistas e institucionalistas, JAEGER observou que o emprego da corrente de pensamento contratualista que admite a definição de interesse comum dos sócios como a solidariedade de interesse típico, específico e ex causa societatis do sócio atual e futuro leva a resultado muito parecido daquele defendido pelas escolas institucionalistas.

De fato, qual mais poderia ser o interesse comum dos sócios atuais e futuros senão o interesse à eficiência e maximização da empresa, ou seja, justamente aquilo que as escolas institucionalistas elegem como o interesse superior que deve orientar o cotidiano societário ${ }^{144}$ ?

Deste modo, segundo o mestre italiano, "una volta concepito l'interesse sociale come um datto típico, sistanzialmente imutabile durante la vita della società, poco importa che esso venga atribuito alla persona giuridica intesa come ente distinto dagli azionisti, o come sintesi normativa delle'insieme degli azionisti, la cui sostanza non muterebbe com il variare delle persone fisiche che assumano tale qualită ${ }^{145}$.

Adotando-se, portanto, uma linha mais pragmática, o interesse social, independentemente da concepção que se adote (seja como resultado do interesse coletivo dos sócios de uma sociedade, seja como manifestação da vontade da própria sociedade) tenta exprimir a idéia de realização do objeto social, ou seja, a maximização das atividades da empresa, da produção, dos mercados, da riqueza empresarial em si, com vistas geração e distribuição de lucros.

\footnotetext{
144 JAEGER, P.G. L'interesse Sociale. Milão: Giuffrè, 1972, p. 88-89.Importante salientar que JAEGER, mais de 40 (quarenta) anos depois, passou a identificar o interesse social à maximização do valor de venda das ações dos sócios (Interesse Sociale Rivisitato - Quarant’anni doppo - In.: Giurisprudenza Commerciale, v. I, 2000, p. 805 e seguintes.

${ }^{145}$ JAEGER, P.G. Op.cit., p. 89.
} 
Nesse sentido, vale relembrar a lição de BULGARELLI ${ }^{146}$, para quem, "Sob um aspecto geral, o interesse da sociedade (e se quiserem, o interesse também da empresa) e o interesse do acionista, considerados ut singuli, ou da soma dos acionistas, são os mesmos: a obtenção dos lucros da sociedade, por intermédio da empresa, e sua distribuição, ou, visto pelo ângulo do acionista, a sua participação nos lucros. " 147

$\mathrm{Na}$ mesma linha de entendimento pode ser mencionado MIRANDA VALVERDE ${ }^{148}$, o qual já dizia que "a sociedade preenche o fim para que foi constituída quando realiza lucros, mediante a exploração de seu objeto".

Destarte, visto por esse prisma, se, pragmaticamente, o interesse social nada representa do que, em breve síntese, a realização do objeto social e a obtenção do lucro, todo interesse que não se acomodar a tal concepção será considerado estranho aos fins sociais ou extra-sociais. Não é outra a posição de FRANÇA ${ }^{149}$ :

\begin{abstract}
"Pode-se concluir, assim, que o interesse da companhia (ou interesse sócia stricto sensu), na Lei $n$. 6.404, constitui um conceito típico e específico, consistente no interesse comum dos sócios à realização do escopo social, abrangendo, portanto, qualquer interesse que diga respeito à causa do contrato de sociedade, seja o interesse à melhor eficiência da empresa, seja a maximização dos lucros, seja a maximização dos dividendos. Em face desse conceito, portanto, qualquer outro interesse comum ou individual dos sócios pode ser classificado como extrasocial".
\end{abstract}

Portanto, de bom alvitre a conclusão, em termos práticos, de que o interesse social deve ser concebido como o interesse consistente na maximização da empresa e do lucro social, por meio da consecução de seu objeto social, sendo considerado como interesse extra-social todo aquele que não se amoldar a tal delineamento.

\footnotetext{
${ }_{147}^{146}$ BULGARELli, W. A Proteção das Minorias nas Sociedades Anônimas. São Paulo: Pioneira, 1977, p. 350.

${ }^{148}$ VALVERDE, T.M. Op.cit, p. 77.

${ }^{149}$ FRANCA, E.V. N. Conflito de Interesses nas Assembléias de S.A. São Paulo: Malheiros, 1993, p.62-63. O Professor Erasmo Valladão difere o interesse social stricto sensu, ou seja, o interesse comum dos sócios enquanto sócios, do interesse social lato sensu, qual seja, aquele perseguido especificamente pelo acionista controlador, conforme parágrafo único do artigo 116 da Lei 6.404/76.
} 


\section{$\underline{\text { 2.1.1.1 - O Interesse social e a orientação de voto nas assembleias das sociedades anônimas }}$}

O caput do artigo 115 da Lei n. 6404/76 inicia prescrevendo que "o acionista deve exercer o direito a voto no interesse da companhia", para depois determinar, no parágrafo primeiro, que o acionista não poderá votar nas deliberações em que tiver interesse conflitante com o da companhia, e, em seguida, no parágrafo quarto, que o acionista que votar nessas condições "responderá pelos danos causados e será obrigado a transferir para a companhia as vantagens que tiver auferido".

Considerando-se, pois, que o interesse da companhia (ou o interesse social), como acima se viu, representa o interesse consistente na maximização da empresa e do lucro social, é correto dizer que o acionista, quando exercer seu direito de voto, deverá fazê-lo em estrita observância a esse intento? Em outras palavras, o voto seria concedido ao acionista tão somente para permitir a consecução do interesse social?

Muito já se discutiu acerca da natureza jurídica do voto, podendo ser destacado, dentre os vários posicionamentos acerca do tema, aqueles the atribuem natureza de direito subjetivo ou de direito-poder ${ }^{150}$.

O direito de voto entendido como direito subjetivo tem origem nas concepções contratualistas da sociedade. Nestes termos, é compreendido como um direito voltado para a satisfação dos interesses individuais dos acionistas, encontrando limitação apenas no interesse comum uti socci dos demais sócios.

Segundo RIBEIRO, os partidários dessa tese defendem que se o acionista não é obrigado a votar, isso significa que o direito de voto pode ser exercido pelo acionista de

\footnotetext{
${ }^{150}$ RIBEIRO, R.V. Direito de Voto nas Sociedades Anônimas. São Paulo: Quartier Latin, p. 169.
} 
acordo com sua conveniência e interesse, o que lhe daria caráter de faculdade e, sendo uma faculdade, seria um direito subjetivo ${ }^{151}$.

Por outro lado, como um direito-poder, o acionista tem o dever de exercer o direito de voto no interesse da sociedade, não podendo utilizá-lo em prol de suas vontades particulares.

Nesse sentido, o direito de voto é entendido mais como um poder jurídico do que como um direito propriamente dito, ou seja, como um instrumento utilizado para proteção do interesse de outrem, que deve ser necessariamente exercido por seu titular, com vistas a assegurar a vontade do ente em favor do qual foi instituído, no caso, a sociedade.

No Brasil, a legislação societária parece ter se inclinado à segunda corrente, ao prescrever que o acionista deverá exercer o direito de voto no interesse da companhia, conforme o caput do artigo 115 da Lei n. 6.404/76. No entanto, mesmo que se reconheça no voto essa tal funcionalidade, não se deve adotar uma rigidez de interpretação nesse sentido, haja vista que a doutrina pátria nunca deixou de tratá-lo como um direito do acionista.

A exemplo, interessante notar como CARVALHOSA relativiza o caráter de poder do voto, ao concebê-lo como "um direito individual do sócio que lhe é conferido, no entanto, com uma específica função, qual seja, a defesa do interesse pessoal harmonizado com o interesse social, dentro dos estritos princípios da boa-fê" ${ }^{152}$.

Parece caber, nesse sentido, a feliz expressão de ASQUINI, para quem o voto seria um "diritto a doppia faccia: de um lado, direito subjetivo, tutelando um interesse individual do acionista; de outro lado, um poder concedido ao acionista no interesse social" ${ }^{, 153}$.

\footnotetext{
${ }^{151}$ Ibdem, idem, p. 170.

${ }^{152}$ CARVAlHOSA, M. Comentários à Lei das Sociedades Anônimas, V. II. São Paulo: Saraiva, 2009, p. 389.

${ }^{153}$ ASQUINI, A. I Batelli del Reno. Rivista delle Società, n.4, 1959, p.631.
} 
Essa linha de entendimento harmoniza-se mais com a correta concepção de que somente o ser humano pode ter interesse em relação a determinado bem, de modo que, nessas condições, o voto não pode ser exercido para tutelar outro interesse senão daquele que o exerce, o qual, independentemente de ser ou não pessoa física, em última instância, será sempre o homem.

Assim, quer parecer que o voto é concedido para a tutela dos interesses do próprio acionista, enquanto membro de uma coletividade, enquanto sócio, interesse esse que deverá ser superior aos seus eventuais outros interesses extra-sociais.

A doutrina nacional e estrangeira parece agasalhar essa tese. Entre os juristas pátrios, cite-se FRANÇA, para quem "parece ajustada à hipótese a já mencionada formulação de Asquini, concebendo o voto como um diritto a doppia faccia: de um lado, direito subjetivo - ao voto - tutelando um interesse individual do acionistas; de outro lado, um poder concedido ao acionista no interesse social ${ }^{\text {"154. }}$.

Ascarelli também já chegou a afirmar que "ecco perché ho recentemente scritto che il voto viene bensì concesso al socio nel suo interesse individuale (e non per um superiori interesse instituzionale), ma nel suo interesse individuale come socio e cioè per la tuleta quel suo interesse che è tuttavia commune anche agli altri soci" ${ }^{155}$, no que foi acompanhado por SENA: "'Il voto verrebbe cosi definito come l'esercizio di um diritto soggestivo collettivo, diritto, attraverso la deliberazioni dell'assemblea, allo svolgimento di un interesse individuale del socio, interesse que si pone tuttavia in posizioni de solidarietà nel rapporto analoghi interessi degli altro soci. ${ }^{156,}$

Por fim, a lição de ROJAS JR., o qual, baseado nos ensinamentos de Rodriguez y Rodriguez, explica que "el voto se concede al socio como un derecho particular de éste para

\footnotetext{
${ }^{154}$ FRANCA, E.V. N. Conflito de Interesses nas Assembléias de S.A. São Paulo: Malheiros, 1993, p. 63-64. ${ }^{155}$ ASCARELLI, T. Studi in Tema di Società. Milão: Giuffrè, 1952, p.

${ }^{156}$ SENA, G. Il Voto nella Assemblea della Società per Azioni: Parte generale. Milão: Giuffrè, 1958, p. 153.
} 
cooperar em la formación de la voluntad colectiva, aun cuando solamente em la medida que su interés personal está identificado com el êxito común que se busca" ${ }^{157}$.

Assim, o acionista, ao votar, deve o fazer na tutela de seus interesses coletivos e comuns aos demais sócios, "ao qual devem se conformar as declarações de vontade de todos os acionistas, sob pena de ser caracterizado como abusivo o voto proferido (art. 115, caput)".

Percebe-se, assim, que o voto proferido em conflito de interesses, ou seja, o voto cuja declaração de vontade foi movida por interesses outros que não o interesse comum de todos os sócios, deve ser considerado abusivo, ilícito. Tal característica do voto conflitado ficará mais evidente a partir da análise da legislação pátria, conforme se verá a seguir.

2.1.2 - O Conflito de Interesses: Evolução legislativa comparada e exegese do artigo $115, \S 1^{\circ}$, da Lei 6.404/76

FRANÇA, em minucioso exame da legislação européia continental, concluiu que "pelo retrospecto histórico do direito brasileiro [...], em confronto com o dos direitos alemão $e$ italiano, pode-se verificar que a evolução de nosso direito se deu em sentido substancialmente semelhante ao daqueles, sobretudo em relação ao italiano"158.

O Professor da Faculdade de Direito do Largo de São Francisco observa que uma norma genérica de proteção aos interesses da companhia contra interesses particulares de acionistas só veio a ser positivada em nosso ordenamento jurídico com o Decreto-Lei $\mathrm{n}^{\text {o }}$ 2.627, de 26 de setembro de 1940.

Referida norma, originada de projeto do emérito Trajano de Miranda Valverde, dispunha, em seu artigo 95, que: "Responderá por perdas e danos o acionista que, tendo em

\footnotetext{
${ }^{157}$ ROJAS JR., L.M. El Derecho de Voto en la Sociedad Anónima. Mexico: Editorial Jus, 1945, p. 182

${ }^{158}$ FRANCA, E.V. N. Conflito de Interesses nas Assembléias de S.A. São Paulo: Malheiros, 1993, p. 81/82.
} 
uma operação interesses contrários aos da sociedade, votar deliberação que determine com seu voto a maioria necessária".

Interessante notar que, ao contrário do atual $\S 1^{\circ}$ do artigo 115 da Lei 6.404/76, o artigo 95 não determinava o impedimento de voto do acionista, mas sim a sua responsabilização na hipótese de exercer seu direito de voto de forma contrária ao interesse social.

Vale dizer, nos termos do artigo 95, o acionista que tivesse um interesse conflitante com a companhia, poderia votar, sendo responsabilizado, todavia, caso, com seu voto, lesasse a sociedade. Tal dispositivo foi influenciado diretamente pelo artigo 197,2 da Lei das Sociedades Anônimas Alemão de 1937 (Aktiengesetz), a qual alterou substancialmente as regras concernentes a tal assunto em relação à legislação anterior ${ }^{159}$.

De fato, o artigo 252 do Código Comercial Alemão (Handelgesetzbuch, ou HGB), que precedeu à promulgação da Aktiengesetz de 1937, proibia o sócio de votar em quatro hipóteses: (i) exoneração de responsabilidade perante a companhia; (ii) liberação de uma obrigação para com a companhia; (iii) conclusão de um negócio entre o sócio e a companhia; (iv) propositura de uma ação por parte da companhia contra o sócio ou transação para extingui-la.

Em todas essas hipóteses, o sócio estava impedido de votar e, caso votasse, o voto estaria eivado de nulidade.

Ocorre que essa sistemática de proibição formal do exercício do direito de voto não foi satisfatória para cumprir seu intento, pois, de um lado, se mostrou muita restrita, tendo em vista os números casos de conflitos de interesses que não eram previstos pela norma, e, de outro, mostrou-se muito rigoroso em relação à hipótese de conclusão de um negócio entre o acionista e a companhia ${ }^{160}$.

\footnotetext{
${ }^{159}$ Ibdem, idem, p. 76.

${ }^{160}$ Ibdem, idem, p. 75-76.
} 
Assim, com o advento da Lei das Sociedades Anônimas Alemão de 1937 (Aktiengesetz), o tema foi tratado com a adoção de um regime dual:

1) o artigo 114,5, previa o impedimento de voto do acionista nas hipóteses de (i) exoneração do acionista de responsabilidade perante a companhia; (ii) liberação de uma obrigação do acionista para com a companhia; e (iii) propositura de uma ação por parte da companhia contra o acionista ou transação para extinguila;

2) o artigo 197,2 determinou a anulação da deliberação decorrente de voto exercido por acionista com o objetivo de obter, para si ou para outrem, vantagens particulares, estranhas à sociedade, e de que resultassem ou pudesse resultar em prejuízos para a companhia ou demais acionistas.

Percebe-se, pois, que a Aktiengesetz de 1937, seguida algum tempo depois pelo Decreto-Lei $\mathrm{n}^{\circ}$ 2.627, de 26 de setembro de 1940, instituiu regime duplo, no qual em algumas situações se impunha o dever de o acionista não votar ao passo, que, em outras, se sancionava o voto com nulidade, sendo a deliberação anulável se o voto nulo tinha contribuído para seu resultado $^{161}$.

Ademais, se comparadas as hipóteses de proibição de voto da Aktiengesetz de 1937 com o HGB, nota-se que, com exceção da hipótese de conclusão de um negócio entre o

\footnotetext{
161 Relembre-se, outrossim, que o Decreto-Lei n 2.627/40 ainda previa em seu artigo 82, que "o acionista não pode votar nas deliberações da assembléia geral relativas ao laudo de avaliação dos bens com que concorrer para a formação do capital social, nem nas que venham a beneficiá-lo de modo particular"; e, no o artigo 100: "Instalada a assembléia geral, proceder-se-á à leitura do relatório, do balanço, da conta de lucros e perdas e do parecer do conselho fiscal. O presidente abrirá, em seguida, discussão sobre esses documentos e, encerrada, submeterá a votação as contas da diretoria, o balanço e o parecer do conselho fiscal. Não poderão tomar parte na deliberação os membros da diretoria e do conselho fiscal”.
} 
acionista e a companhia, todas foram recepcionadas pela Lei Acionária. A doutrina ${ }^{162}$ aponta que aquela hipótese foi eliminada por se mostrar muito rígida em relação às situações do caso concreto, pois nem todos os casos de conclusão de um negócio entre o acionista e a companhia poderiam ser prejudiciais à sociedade.

A sistemática Aktiengesetz de 1937 foi mantida pela Lei de 1965, com pequenas alterações $^{163}$ :

1) o artigo 136,1 estabelece a proibição do exercício do direito de voto quando o acionista deva deliberar sobre a aprovação de suas próprias contas, a exoneração de suas obrigações para com a sociedade, ou ao exercício de direitos que esta tenha em relação ao mesmo;

2) o artigo 243,2 determina a anulação da deliberação quando o acionista tentar obter, pelo exercício de seu direito de voto, para si ou para terceiros, vantagens particulares em detrimento da sociedade ou de outros acionistas.

LEÃES aponta ainda algumas diferenças entre a Aktiengesetz de 1965 e a de 1937. Para tal autor, a eliminação do advérbio "intenção" ou "vorsatzlich", expressaria que "basta que o sócio, ao votar, tenha tentado obter vantagens especiais, necessariamente extrasociais, para que se configure o conflito", ao passo que a "fórmula zu erlangen suchte ("tentar obter'), utilizada na lei de 1965, deflui a idéia de que o conflito se instaura com a ocorrência de dano potencial, sem que se exija a evidência de prejuízo efetivo para a caracterização do conflito" ${ }^{164}$.

Resta, por fim, apontar que a Lei Acionária Alemã de 1965 excluiu da hipótese de anulabilidade a deliberação que, embora orientada por voto que buscasse vantagem particular,

162 GALGANO, F. La Società por Azioni, vol. 7 do Trattado di Diritto Commerciale e di Diritto Publicco dell`Economia apud FRANCA, E.V.N., Op.Cit, p. 76 (nota de rodapé).

${ }_{163}$ Op. Cit, p. $76 / 77$

${ }^{164}$ LEÃES, L.G.P.B. Proibição de Voto e Conflito de Interesses nas Assembléias Gerais in Pareceres, São Paulo: Singular, 2004, p. 177.. 
atribuísse aos demais acionistas "compensações adequadas" (angemessener Ausgleich), cabendo se analisar, caso a caso, se tais compensações foram mesmo adequadas ${ }^{165}$.

Já no que se refere ao Direito Italiano, cumpre mencionar que o artigo 162 do Código Comercial impedia o voto do acionista administrador nas deliberações de aprovação de suas contas ou naquelas que versassem a respeito de sua própria responsabilidade, ao passo que o artigo 150 do mesmo Diploma Legal orientava o administrador a se abster de votar a respeito de matéria em que tivesse contrário à sociedade, sob pena de ter que responder pelos prejuízos causados.

Conforme relata FRANÇA, muito se discutiu na doutrina italiana se ambas as situações poderiam ser consideradas divieto de voto (proibição de voto) ou se o correto seria adotar o regime diferenciado, tal como no direito alemão ${ }^{166}$.

O Código Civil Italiano de 1942, por sua vez, tratou do assunto em um único dispositivo, o artigo 2373, nos seguintes termos:

1) Primeira parte: $O$ direito de voto não pode ser exercido pelo sócio nas deliberações em que ele tenha, por conta própria ou de terceiro, um interesse em conflito com o da sociedade. Em caso de inobservância desse preceito, a deliberação, toda vez que possa causar dano à sociedade é impugnável, se, sem o voto dos sócios que deveriam se abster da votação, não se teria alcançado a maioria necessária.

2) Os administradores não podem votar nas deliberações concernentes a sua responsabilidade.

Não há como não notar uma diferença significativa entre as normas alemã e italiana: o texto da Aktiengesetz de 1965 é claro ao não mencionar a proibição de voto no caso

\footnotetext{
165 Op.cit, p. 78.

${ }^{166}$ Op.cit, p. 78.
} 
de conflito de interesse, o que não ocorre com o texto do artigo 2373 do Código Civil Italiano de 1942, não serenando as discussões doutrinárias acerca do tema ${ }^{167}$

Todavia, a reforma da legislação italiana de 2003 veio colocar um termo final às discussões, ao prescrever o seguinte ${ }^{168}$ :

1) Primeira Parte: A deliberação aprovada com o voto determinante daquele que possui, por conta própria ou de terceiro, um interesse em conflito com o da companhia, é impugnável nos termos do artigo 2377, na hipótese de trazer qualquer dano à companhia;

2) Os administradores não podem votar nas deliberações que digam respeito à sua própria responsabilidade

Assim, atualmente, tanto a legislação alemã como italiana não determina o impedimento de voto do acionista na hipótese de conflito de interesses, mas apenas a sua responsabilização, na hipótese de prejudicar a companhia ao tentar obter vantagens indevidas.

A razão de tal homogeneização de tratamento reside no fato de que o instituto do conflito de interesses pressupõe o dano, o prejuízo à companhia para sua configuração, não podendo ser apurado aprioristicamente, pois somente após a comprovação do dano é que o conflito de instauraria.

\footnotetext{
${ }^{167}$ Para superar essa questão, GALGANO defendia que se trata de uma proibição acautelatória, pois, não se sabendo, a priori, qual dos interesses o sócio irá querer satisfazer (se o seu particular ou o da companhia), a norma impõe, cautelarmente, que ele se abstenha de votar. Assim, caso ele vote, e seu voto contribuir para o resultado da deliberação e puder lesionar a sociedade, a deliberação poderá ser anulada. Destarte, segundo ao autor italiano, a deliberação não será anulada apenas porque o acionista votou, assumindo relevância, assim, examinar o conteúdo de seu voto, o modo como votou (cf. FRANÇA, E.V.N. Op.cit. p. 80).

168 Texto original: Art. 2373. La deliberazione approvata con il voto determinante di coloro (1) che abbiano, per conto proprio o di terzi, un interesse in conflitto con quello della società è impugnabile a norma dell'articolo 2377 qualora possa recarle danno.

Gli amministratori non possono votare nelle deliberazioni riguardanti la loro responsabilità. I componenti del consiglio di gestione non possono votare nelle deliberazioni riguardanti la nomina, la revoca o la responsabilità dei consiglieri di sorveglianza.
} 
O conceito do conflito de interesses atrelado ao dano, ao ilícito, ao abuso está contido na legislação brasileira, muito embora haja a previsão de impedimento de voto por conflito de interesses ${ }^{169}$. No entanto, quanto a esse último ponto, parece ter seguido na linha do texto original do Código Civil Italiano de 1942, instituindo uma proibição acautelatória para a hipótese de conflito e uma proibição in re ipsa para as demais situações ${ }^{170}$.

Mas o que salta aos olhos, realmente, é a vinculação do voto conflitado ao voto abusivo. Com efeito, não é demais afirmar que o voto conflitado, de acordo com o $\$ 1^{\circ}$ do artigo 115 da Lei ${ }^{\circ}$ 6.404/76, consiste em uma espécie do voto abusivo.

O artigo 115 da Lei $n^{\circ} 6.404 / 76$, em seu $\S 1^{\circ}$, prescreve que o acionista não poderá exercer seu direito de voto em situações em que tiver interesse conflitante com a companhia, consignando, todavia, em seu $\S 4^{\circ}$, que, caso o exerça, responderá pelos prejuízos causados e transferirá para a companhia as vantagens que tiver obtido.

\footnotetext{
${ }^{169}$ FRANÇA entende que a regra atual da Lei $n^{\circ}$ 6.404/76 foi influenciada pela evolução legislativa alemã e italiana. Segundo ele, a Lei $n^{\circ} 6.404 / 76$ instituiu tratamento para o abuso de direito de voto em tudo parecido com a sistemática alemã, considerando abusivo o voto exercido com o fim de lesar a companhia ou demais acionistas ou com o intuito de obter vantagens a que não faz jus e que resulte, ou possa resultar, em prejuízo para a companhia ou para outros acionistas (FRANÇA, E.V.N. Op.cit. p. 82). Não é outro, a propósito, o pensamento do professor LEÃES: "Já na hipótese de conflito de interesses, cabe uma indagação relativamente ao mérito da deliberação da assembléia, para a qual foi decisivo o voto do acionista, para se apurar se há ou não a incompatibilidade entre os interesses do acionista e os da companhia, manifestada no voto do acionista (vale dizer, cabe apurar se há abuso no exercício do direito de voto). Nessa hipótese, o controle é ex post, de onde se deduz deva ser considerado caso a caso, para efeito de sua eventual anulação. A Lei $n .6404$ acolhe esse regime dualista do direito alemão e italiano, agasalhando até redação assemelhada na regulação da matéria" (Proibição de Voto e Conflito de Interesses nas Assembléias Gerais in Pareceres, São Paulo: Singular, 2004, p. 179).

170 Conforme FRANÇA “ a lei não está se reportando a um conflito meramente formal, mas sim a um conflito substancial, que só pode ser verificado mediante o exame do conteúdo da deliberação. Tal como na Itália, pois, a lei, nessa hipótese, proíbe, cautelarmente, o acionista de votar. Se o acionista vota, deve se verificar, então, o modo como que votou: se, efetivamente, sacrificou o interesse da companhia ao seu interesse pessoal, com prejuízo, potencial ou atual à companhia ou a outros acionistas, seu voto será nulo, bem como anulável a deliberação tomada, se o voto foi decisivo para a formação da maioria. Em suma, a lei não estabeleceu, para a situação, um divieto de voto, como o fez para as demais hipóteses do \$1 ${ }^{\circ}$ do art. 115”(Op.cit., p. 97).
} 
Por outro lado, o caput do artigo 115 reza que o voto abusivo é aquele proferido com fim de causar dano à companhia ou a seus acionistas, podendo ser auferido, em contrapartida, vantagem a que não faz jus.

Deste modo, comparando-se os institutos, percebe-se que ambos têm o condão de causar prejuízos e provocar a obtenção de vantagens indevidas, com a diferença que o voto abusivo é mais amplo, podendo ser exercido em detrimento da companhia ou dos demais acionistas, ao passo que o voto proferido em conflito de interesses pode prejudicar apenas a companhia.

Com efeito, o embate de interesses a ensejar o conflito se dá no âmbito da relação acionista-companhia e não da relação acionista-acionista, não sendo tutelado pelo nosso ordenamento jurídico o conflito de interesses entre acionistas, de modo que eventuais prejuízos causados a um acionista por outro acionista no âmbito de uma assembleia serão tratados pelo instituto do voto abusivo.

Assim, o voto conflitado nada mais representa do que o voto abusivo que acarreta danos à companhia. Deste modo, como declarar o conflito de interesses sem antes averiguar a ocorrência de danos à companhia?

Ademais, se o acionista possui um duplo interesse, o interesse enquanto acionista e o interesse individual, em uma deliberação, como saber, previamente, qual o interesse o acionista irá sacrificar? Até mesmo porque, "se o acionista tem interesse conflitante com o da companhia, mas vota efetivamente no interesse desta, e não em outro interesse extra-social, o exercício de voto regular é válido". ${ }^{171}$

Desta forma, fica difícil conceber uma proibição a priori do voto do acionista conflitando, pois somente é possível verificar se o acionista sacrificou o interesse social em

\footnotetext{
${ }^{171}$ Trecho de parecer apresentado nos autos do Inquérito Administrativo CVM 2002/1153 e constante de voto do Diretor Luiz Antônio de Sampaio Campos, proferido em 6 de novembro de 2002.
} 
prol de seu particular caso a caso, analisando as circunstâncias e, principalmente, as conseqüências do voto, sendo a existência do prejuízo um significativo indicador.

Em outras palavras, o conflito de interesses não restará configurado caso não provoque prejuízo à companhia, de forma que sua caracterização apenas poderá ser apurada casuisticamente $^{172}$.

\section{$\underline{2.1 .3-O}$ Conflito de Interesses: a vantagem ilícita}

A partir da exegese da norma pátria e da análise de sua evolução atrelada ao direito comparado, pode-se concluir, portanto, que o instituto do conflito de interesses pressupõe o ilícito, o prejuízo, o dano à companhia. Assim, a vantagem que o acionista conflitado persegue, nos termos do $\S 4^{\circ}$ do artigo 115 da Lei $n^{\circ}$ 6.404/76 é uma vantagem que o acionista não faz jus, uma vantagem não tutelada pelo direito. Ilícita, portanto.

No conflito de interesses, relembrando-se as lições de CARNELUTTI, a satisfação do interesse de um significa a destruição do interesse do outro. Assim, a simples existência de

\footnotetext{
${ }^{172}$ Muito já se discutiu acerca da verificação ex ante ou ex post do conflito de interesses, na doutrina e na jurisprudência. De fato, parte da doutrina entende que o conflito de interesses, assim, como as demais hipóteses previstas na lei, pode ser configurado formalmente, estando o acionista interessado impedido de votar aprioristicamente. Como defensores dessa corrente podem ser apontados CARVALHOSA (Comentários à Lei das Sociedades Anônimas, V.II, São Paulo: Saraiva, 2003, p. 466), FERREIRA (cf. BULHOES PEDREIRAS, J.L; LAMY FILHO, A.A Lei das S.A., Renovar, 2a ed., 2o volume, pág. 239 e 240), WALD (A Evolução do regime legal do Conselho de Administração, os Acordos de Acionistas e os Impedimentos de Votos dos Conselheiros decorrentes de Conflitos de Interesses. Revista de Direito Bancário, do Mercado de Capitais e da Arbitragem $\mathrm{n}^{\circ} 11$ pp 13-30), PENTEADO (Aumento de Capitais nas Sociedades por Ações. Tese apresentada ao Departamento de Direito Comercail da Universidade de São Paulo para obtenção do título de Doutor em Direito, 1896, p. 264), RIBEIRO (Direito de Voto nas Sociedades Anônimas. São Paulo: Quartier Latin, 2009) e URIA (Derecho Mercantil. Madrid : Marcial Pons, 1995, p. 308). Por outro lado, muitos são os defensores do conflito material de intereses, aquele que somente pode ser configurado com a existencia do daño causado à companhia. Dentre eles, FRANÇA (Conflito de Interesses nas Assembleias de S.A. São Paulo: Malheiros, 1993), LEAES, MIRANDA VALVERDE (Sociedade por Ações, Vol. II, 2. ed. Rio de Janeiro: Forense, 1953, p. 69), CUNHA PEIXOTO (Sociedades por Ações, Vol. III, São Paulo: Saraiva, 1973, p. 81), CARVALHO DE MENDONÇA (Tratado de Direito Comercial Brasileiro, v. IV. São Paulo: Freitas Bastos, 1946, p. 64), MARTINS (Op.cit., v. II, p. 84), GUERREIRO (Conflitos de Interesse entre Sociedade Controladora e Controlada e entre Coligadas no Exercício do Voto em Assembléias Gerais e Reuniões Sociais. Revista de Direito Mercantil, n. 51, jul-set/83, PP. 29-32) e CUNHA (Estrutura de Interesses nas Sociedades Anônimas. São Paulo, Quartier Latin, 2007, p. 282). A Comissão de valores Mobiliários em várias oportunidades também já discutiu o tema, ora se posicionando pelo conflito formal (Inquérito Administrativo CVM no TA/RJ 2001/4977; Processo Administrativo $n^{\circ}$ RJ 200913179) e ora se posicionando pelo conflito material (Inquérito Administrativo CVM no TA/RJ 2002/1153).
} 
dois interesses distintos não pressupõe o conflito, pois, de fato, como acima se observou, os interesses podem ser solidários entre si, como no caso do sócio que busca seu interesse particular e extrassocial sem prejudicar o interesse da própria sociedade ${ }^{173}$.

De fato, imagine-se uma hipótese de conclusão de um negócio entre acionista e a companhia, no qual as condições oferecidas à companhia são idênticas e até melhores às obtidas no mercado. Nestas circunstâncias, o acionista tem um interesse extrassocial, de que haja a celebração do negócio com a companhia. Todavia, a satisfação desse interesse em nada prejudicará os interesses da companhia, pelo contrário, também lhe proporcionará vantagens, pois será um negócio também bom para a própria sociedade.

Em uma situação como essa, haveria conflito de interesse? Evidente que não pois, como preceitua BULHÕES PEDREIRA, "o ato ilícito consiste em votar interesse contrário ao da companhia e não em votar tendo um interesse extrassocial" ${ }^{, 174}$.

Assim, quer parecer que o voto proferido em conflito de interesse pressupõe o voto exercido com o intuito de satisfazer interesse extra-social, em detrimento do interesse social, comum a todos os sócios, com vistas a obter vantagem ilícita, que não faz jus, causando, com isso, prejuízos à companhia.

\subsection{O Conflito de Interesses e o Benefício Particular}

A partir desse ponto, parece ser possível estabelecer algumas distinções entre ambos os institutos, de modo a traçar uma mínima fronteira entre eles, possibilitando maior segurança jurídica em suas aplicações no cotidiano societário.

\footnotetext{
${ }^{173}$ CARNELUTTI, F. Op.cit. p. 88.

${ }^{174}$ Trecho de parecer apresentado nos autos do Inquérito Administrativo CVM 2002/1153 e constante de voto do Diretor Luiz Antônio de Sampaio Campos, proferido em 6 de novembro de 2002.
} 
Por mais que a princípio possa parecer tênue a linha divisória entre ambos os institutos, há que se ter em mente de que são institutos diversos, voltadas para situações distintas.

A grande confusão que se faz entre esses dois institutos de direito societário é decorrente da semelhança de matéria tratada. Com efeito, em ambas as hipóteses, o que está em foco é o interesse particular do acionista. No benefício particular, como se demonstrou, o intuito do legislador foi regrar a matéria para não permitir que o acionista interessado vote favoravelmente a si tema que lhe diga respeito direta e exclusivamente ${ }^{175}$. No conflito de interesse, o objetivo da norma foi evitar que o interesse particular do acionista prepondere sobre o interesse social ${ }^{176}$.

Todavia, as semelhanças param por aí. De fato, no próprio objetivo do legislador já se denotam diferenças, ou seja, a razão de ser de ambos os institutos é distinta: no conflito de interesse o objetivo da norma foi proteger o interesse social, ao passo que no benefício particular, o intuito foi satisfazer preceito de ordem ética, para afastar os inconvenientes de uma pessoa julgar favoravelmente os próprios atos (Nemo Iudex In Causa Própria).

Vale dizer, o legislador buscou, com a criação do instituto do conflito de interesse, tutelar a própria companhia contra atos praticados por seus acionistas em prol de seus interesses extra-sociais. $\mathrm{O}$ instituto do conflito de interesses, assim, pode ser classificado como um genuíno Direito de Minoria ${ }^{177}$.

\footnotetext{
175 Vide MIRANDA VALVERDE, Sociedade por Ações, Vol. II, , p. 66/67; Lopes Pontes, Sociedades Anônimas, Vol. I, 3. p. 430/431; CARVALHO DE MENDONÇA, Tratado de Direito Comercial Brasileiro, Vol. II, p. 346/349.

${ }^{176}$ Vide FRANÇA, Conflito de Interesse nas S.A, p. 97; Leães, Op.cit.. Para o Diretor da CVM Otávio Yazbek (Caso Tractebel): Tanto assim que, para mim, o que a Lei cria, ao lidar com os conflitos de interesses, é um regime protetivo da integridade da formação de vontade da sociedade.

${ }^{177} \mathrm{O}$ conceito de Direitos de Minoria foi construído gradativamente. Inicialmente, a fonte de proteção societária estava contida nas regras contidas nos estatutos sociais das companhias. Por conter as normas essenciais e específicas pelas quais será regida a companhia, tais como as relativas à definição de seu objeto social, às políticas de sua gestão e governança e aos direitos e deveres de seus sócios, o estatuto social sempre foi tratado como o principal documento assecuratório da lisura dos atos societários, sendo, ademais, a grande carta informadora, a eventuais investidores, das principais características da sociedade. O jurista italiano FERRI, em sua clássica obra "La Tutella della Minoranze Nella Società per Azioni” aborda o assunto de forma muito clara.
} 
Diferente, pois, é o instituto do benefício particular, que não tem por função proteger o interesse social, até porque, frente à vantagem lícita, que não acarreta danos, o interesse social prescinde de proteção. O que visou o legislador ao criar tal instituto foi garantir a lisura das atribuições de vantagens a acionistas e fundadores, de forma a coibir o mal uso, afastando os inconvenientes de uma pessoa ser juiz de seus próprios atos. Assim, para o benefício particular, o impedimento de voto está mais associado a uma falta de legitimação do acionista para tratar de tema que lhe diga respeito do que como uma proteção de garantia dos interesses sociais.

Segundo o jurista italiano, a doutrina européia de um modo geral sempre procurou tutelar a dita estabilidade estatutária. Nesse sentido, relata o jurista italiano que LYON-CAEN e HOUPIN, na França, fundando-se em uma concepção mais contratualística das sociedades anônimas, afirmavam que as regras constantes dos estatutos sociais das companhias apenas poderiam ser alterados mediante a deliberação unânime dos sócios (Traité de Droit Commercial, $3^{\mathrm{a}}$ ed, II, n. 864; apud FERRI, G. Op.cit., p. 16).Entretanto, a prática demonstrou que condicionar a alteração estatutária apenas à deliberação unânime dos sócios era equivalente a imobilizar o funcionamento do organismo social, impedindo a adaptação às novas circunstâncias. Não tardou, assim, para que a doutrina e a jurisprudência passassem a mitigar a regra da estabilização estatutária, permitindo que sua modificação se desse, em certos casos, via aprovação por maioria dos sócios, desde que certos direitos permanecessem inalterados.

Surge, assim, na França, a Teoria das Bases Essenciais, a qual previa que certas disposições estatutárias, relativas às características precípuas da companhia, tais como objeto social, duração, hipóteses de liquidação, etc., bem como as que versam sobre direitos inerentes à qualidade e à posição de sócio (direitos próprios de acionista), não poderiam ser alteradas pela maioria acionária.

Os chamados direitos individuais de acionistas tinham por função proteger, precipuamente, seus direitos patrimoniais frente às sociedades, cujas regras somente poderiam ser alteradas ou suprimidas com a aprovação da unanimidade de sócios.

Ocorre que a prática demonstrou que havia certas deliberações em que alguns acionistas poderiam ser prejudicados, não obstante seus direitos individuais se manterem intactos. Assim, como bem assevera Ferri, fora dos limites desenhados pelas teorias acima observadas, o sócio controlador teria o pleno espaço para impor sua vontade como bem lhe aprouver, tal como nas condições em que o acionista contratasse com a companhia em condições de favorecimento (FERRI, G. Op.cit. p. 27).

Desta maneira, para a plena proteção aos acionistas, a doutrina percebeu que era necessário, em verdade, utilizarse de duas espécies de direitos: assim, ao lado dos direitos de cunho patrimonial, outro também deveria ser levado em consideração, qual seja, o direito de participar do cotidiano da vida societária, de votar nas deliberações sociais e de fiscalizar a gestão social, o que a doutrina posteriormente denominou Direitos de Minoria (SCHIMIDT, D. Les Droits de La Minorité das La Société Anonymme. Paris: Sirey, 1970, p. 36/37).

Segundo o mestre francês, "o direito é dito social porque não serve para proteger ou garantir os interesses do acionista que o exerce, mas porque permite que o acionista interfira na vida societária com a finalidade de assegurar a boa gestão dos interesses sociais" (op.cit, p. 37). Assim, percebe-se que uma característica essencial aos direitos sociais ou de minoria é que tais direitos são exercidos no exclusivo interesse social, visando sua tutela. Daí o conflito de interesse ser considerado como um Direito de Minoria. 
Se o instituto do conflito de interesses tem por razão de ser a proteção do interesse social, imperioso admitir que, quando instalado, a vantagem eventualmente auferida pelo acionista interessado só pode ser ilícita, pois obtida em função do sacrifício do interesse social.

Com efeito, o ilícito, a irregularidade, é condição para a caracterização do instituto do conflito de interesse. Conforme se viu, o voto conflitado é decorrente do embate entre dois interesses pertencentes ao acionista: o interesse ex societatis comum a todos os sócios e o interesse extra-social de um determinado acionista.

Como é da natureza do conflito de interesses a impossibilidade do mesmo bem pretendido satisfazer a ambas as necessidades em sua plenitude, o acionista conflitado, ao exercer seu direito de voto sacrificará, mesmo que minimamente, um interesse. Se o interesse prejudicado for o interesse social, estará configurado o conflito.

Por essa razão, por pressupor o sacrifício, a lesão ao interesse social, o conflito de interesse está assentado na irregularidade, no dano, no prejuízo decorrente da violação do interesse social. Assim, o voto proferido em conflito de interesse é um voto abusivo, nos termos do caput do artigo 115 da lei das Sociedades por Ações.

Já o benefício particular consiste em vantagem lícita perseguida pelo acionista, não tolhida pela legislação, vantagem que poderá ser a ele atribuída, desde que conte com a aprovação dos demais acionistas.

Trata-se, pois, de concessão que se faz às claras, sem subterfúgios, justamente porque a obtenção da vantagem consistente no benefício particular não pressupõe qualquer irregularidade, podendo a assembleia atribuir vantagem particular a qualquer acionista. Vale dizer, observado o mecanismo de aprovação do benefício particular, não haverá que se falar em ilícito ou na ocorrência de dano a quem quer que seja ${ }^{178}$.

\footnotetext{
178 "Se o voto deve ser dado tendo em vista o interesse social e não os interesses particulares dos acionistas, se uma deliberação visa a beneficiar, de modo particular, o acionista é natural que este não concorra para a aprovação dessa deliberação. Não quer isso significar, entretanto, que a assembleia não possa deliberar no
} 
Destarte, se a instauração do benefício particular não pressupõe a ocorrência de qualquer irregularidade ou ilícito, forçoso concluir que sua realização não está associada à existência de qualquer prejuízo à companhia ou aos demais acionistas.

Daí a principal diferença entre o conflito de interesses e o benefício particular: no primeiro caso, pelo potencial prejuízo à companhia envolvido, pressupõe-se o choque, o confronto, ou, como o próprio nome diz, o conflito dos interesses do acionista e da companhia, de modo que o exercício de um implica, necessariamente, no sacrifício do outro (daí o prejuízo).

Isso não ocorre no benefício particular. Vale dizer, não há configuração de conflito, de embate entre interesses. $\mathrm{O}$ interesse particular do acionista em ver aprovada uma deliberação que lhe conceda uma vantagem particular pode até mesmo coincidir com os interesses sociais, como, por exemplo, conceder proventos de aposentadoria a determinado acionista que desempenhou papel chave na organização.

Dito de outra forma, pode-se afirmar que nos casos de conflitos de interesse, há um interesse particular do acionista que, impreterivelmente, entra em choque com os interesses da companhia, ensejando a obtenção de vantagens ilícitas. Nos casos de benefício particular, o que há é somente esse interesse particular do acionista em relação à determinada matéria que lhe possa resultar em uma vantagem particular lícita, não havendo que se falar em choques, embates ou prejuízos pois, se assim o for, não se está diante de uma situação de benefício particular, mas de conflito de interesses.

sentido de conceder benefício particular a determinados acionistas; assim pode acontecer e é lícito à assembleia deliberar a respeito, desde que haja uma justificação plausível para o caso; o que não deve acontecer é a participação do acionista, através do voto, na deliberação que lhe concede vantagens especiais" (MARTINS, F. Comentários à Lei das Sociedades Anônimas: Artigo por artigo. 4ª Ed. Rio de Janeiro: Forense, 2010). 
$\mathrm{O}$ argumento supra encontra guarida em FRANÇA ${ }^{179}$ : "Então, esta é a distinção, no meu entender. O benefício particular é a vantagem lícita, que pode ser outorgada estaturiamente, mas que impede o acionista beneficiário de votar, porque não há condições de aferir se ela é equitativa ou não. Tem um caráter de liberalidade, mesmo quando se trata de compensar serviços prestados. E o conflito de interesses é a vantagem ilícita, abusiva, que o acionista busca com o exercício do voto, em detrimento, atual ou mesmo potencial, da companhia ou outros acionistas".

Daí com razão RIBEIRO ${ }^{180}$, quando afirma que “a existência de interesse individual do acionista não indica, necessariamente, interesse contrário ao social, pelo que se exige também relação de antagonismo [...]. Não há conflito de interesses se o interesse particular do sócio for convergente com o da sociedade. Mesmo que isso traga uma vantagem adicional ao acionista."

Desta forma, muito embora o conflito de interesses pressuponha uma vantagem particular (pois, para haver conflito, há de haver um interesse particular que tenha a pretensão de obter uma vantagem particular), não há como co-existir, em um mesmo evento, o instituto do benefício particular com o instituto do conflito de interesses, pois, em um caso a vantagem será ilícita e noutro, lícita, sendo o limite entre um caso e outro a possibilidade de violação do interesse social.

Nesse sentido, equivocado o entendimento de que o conceito de benefício particular está contido no conceito de conflito de interesses, pois a vantagem que o acionista conflitado com o da companhia experimenta não é uma vantagem lícita e a vantagem do benefício particular só pode ser lícita.

Assumir, portanto, que o conceito de um está atrelado ao outro na medida em que o acionista conflitado obtém, necessariamente, um benefício particular, em detrimento da

\footnotetext{
${ }^{179}$ FRANÇA, E.V.N. O Conceito de Benefício Particular e o Parecer de Orientação 34 da CVM In. Temas de Direito Societário, Falimentar e Teoria da Empresa. São Paulo: Malheiros, 2009, p. 577.

${ }^{180}$ RIBEIRO, R.V. Direito de Voto nas Sociedades Anônimas. São Paulo: Quartier Latin, p. 370/371.
} 
companhia, é não considerar a expressão "benefício particular" na acepção técnica do termo, desprezando toda a história de construção conceitual do instituto. ${ }^{181}$

O parâmetro da licitude, por si só, já pode ser usado para diferenciar ambos os institutos na prática, pois, por mais que seja evidente que uma determinada operação ou negócio está, em termos semânticos, beneficiando particularmente um acionista, não poderá ser considerado como tal se a vantagem obtida, de alguma forma, é fruto de um ilícito ou de uma irregularidade qualquer.

Entretanto, outros critérios podem ser utilizados, como a relação do destinatário da vantagem em relação à sociedade.

O benefício particular, como acima se demonstrou, é a vantagem atribuída ao acionista que rompe a igualdade existente entre os sócios detentores de ações de uma mesma classe e espécie, interferindo no alcance aos fundos sociais. Se assim o é, tal vantagem somente pode ser concedida ao acionista na qualidade de acionista, ou seja, enquanto membro da relação societária mantida com a companhia. Em outras palavras, a vantagem do benefício particular é uma vantagem que, em princípio, qualquer acionista poderia obter, sendo bastante, para tanto, sua própria condição de acionista.

Já o conflito de interesses não representa, na maior parte das vezes, uma vantagem que o acionista poderia obter na condição de acionista, sendo comum tomar a forma de uma vantagem de natureza extra-social, como nas situações em que o acionista contrata com a companhia.

Deste modo, as vantagens associadas aos chamados contratos consigo mesmo jamais poderiam representar um benefício particular, pois decorrentes de diversa relação

\footnotetext{
${ }^{181}$ Como exemplos de autores que defendem a ideia de que o conceito de benefício particular está contido no conceito de conflito de interesses pode-se citar Nascimento (Conflito de Interesses no Exercício do Direito de Voto nas Sociedades Anônimas ( $2^{\mathrm{a}}$ parte). Revista de Direito Bancário, do Mercado de Capitais, n. 25, ano 7 , jul-set 2004, p. 97) e PENTEADO JR.(A disciplina da abstenção do voto ma legislação das S.A. In: Vidigal, Geraldo de Camargo e Martins, Ives Gandra (Coords). Sociedade por Ações - Estudo n. 20. São Paulo: Resenha Universitária, 1981, p. 1301).
} 
jurídica mantida pelo sócio em face da companhia. Mesmo na hipótese de a vantagem auferida pelo sócio-contratante não ser ilícita (como, por exemplo, nos casos de contratos celebrados em condições estritamente comutativas), não se pode falar em benefício particular, pois a vantagem não é decorrente da condição de sócio mantida pelo acionista.

Aliás, nesse último caso, sequer o conflito de interesse estaria configurado, uma vez que contratos celebrados em condições comutativas não ensejam qualquer prejuízo a quem quer que seja.

Um terceiro aspecto a ser considerado é o caráter da liberalidade contida no instituto do benefício particular, algo completamente distinto do que ocorre no conflito de interesses: no benefício particular, a vantagem é concedida deliberadamente pela sociedade, por meio da aprovação dos demais sócios, ao sócio beneficiado.

Vale dizer, no caso do benefício particular a sociedade quer, deseja conceder a vantagem ao sócio, tal como um prêmio, enquanto que no conflito de interesse a vantagem é auferida pelo acionista contra a "vontade da sociedade", de forma impositiva e irregular, violando-a, por assim dizer.

Assim, o ato que não tiver caráter de liberalidade não pode ser considerado como benefício particular, devendo, outrossim, ser averiguada a existência de lesão ao patrimônio social para se buscar a configuração do conflito de interesses.

Por fim, vale a pena consignar que a mera possibilidade de atribuição de um benefício particular a um determinado acionista é suficiente para justificar o impedimento do exercício de seu direito de voto, tal como prescrito na legislação pátria, na medida em que o legislador, fundado no preceito ético nemo iudex in causa propria, quis tão somente que os demais acionistas, expressamente, chancelassem a concessão de tal vantagem, em qualquer hipótese. 
Até por essa razão, o impedimento de voto no caso do benefício particular se faz de forma objetiva, não havendo que se perquirir qualquer elemento ou se realizar qualquer juízo de valor para definir se o acionista deve ou não votar: basta a pauta da assembleia colocar na ordem do dia a aprovação da concessão de uma vantagem exclusiva a um determinado acionista, sendo, pois, verdadeira hipótese de divieto de voto, utilizando-se do termo empregado no Direito Italiano, como se demonstrou no capítulo anterior, ao contrário do conflito de interesses, cuja configuração, conforme acima se mencionou, só pode ocorrer ex post, na medida em que apenas depois é que se poderá apurar se o voto proferido causou prejuízos à companhia. 


\section{III - APLICAÇÕES PRÁTICAS DO BENEFÍCIO PARTICULAR E A JURISPRUDÊNCIA DA COMISSÃO DE VALORES MOBILIÁRIOS}

Nos últimos dez anos, o instituto do benefício particular vem sendo cada vez mais relembrado nas discussões no âmbito da Comissão de Valores Mobiliários.

Isso se deve, em parte, ao próprio crescimento e desenvolvimento da economia nacional, e, por conseguinte, dos grupos corporativos, os quais tenderam a buscar a consolidação dos mercados, com vistas a fortalecer suas operações, proteger-se contra a concorrência externa e ampliar suas margens de retorno.

Com efeito, a consolidação de empresas tornou-se, ultimamente, crescente dentro do cenário econômico brasileiro, ensejando o surgimento de reestruturações societárias de um modo geral, com destaque para as fusões e incorporações, inclusive de ações.

Conforme adiante se verá, têm sido comum as discussões sobre a aplicação do instituto do benefício particular surgirem no seio dessas operações de fusão e incorporação, decorrentes, muitas vezes, de reclamações de acionistas que se sentiram lesados pela participação do acionista supostamente beneficiado com a operação no conclave que decidiria acerca de sua aprovação.

Também já visitaram as sessões de julgamento da CVM discussões sobre ocorrência de benefício particular em contratações entre partes relacionadas, embora, nos últimos anos, tal discussão venha perdendo força.

Vale relembrar, ainda, que os acionistas, com a globalização dos mercados, dos negócios e das informações, têm se tornado cada vez mais adeptos da cultura do "ativismo acionário", passando a participar das deliberações assembleares e a valorizar as boas práticas 
de governança corporativa, contribuindo, assim, de um modo geral, para o aumento das discussões envolvendo seus direitos.

Natural, assim, que ganhasse impulso os debates sobre aplicação do benefício particular, uma vez que, pela força que carrega, impedindo o voto do acionista beneficiado, pode interferir diretamente no resultado das assembléias gerais das sociedades anônimas.

Assume grande importância, assim, definir os contornos de aplicação do instituto do benefício particular, de modo que não se distorça sua finalidade maior, qual seja, não permitir que o acionista interessado vote favoravelmente a si tema que lhe diga respeito diretamente.

Portanto, o objetivo do presente capítulo é analisar algumas situações cotidianas do universo societário de modo a verificar a existência ou não do benefício particular.

\section{$\underline{3.1 \text { - Transacões com Partes Relacionadas }}$}

Conforme a Deliberação $n^{\circ} 560$ de 2008, da Comissão de Valores Mobiliários, entende-se por parte relacionada a uma determinada entidade a parte que, direta ou indiretamente, por meio de um ou mais intermediários, (i) controlar, for controlada por, ou estiver sob o controle comum da entidade; (ii) tiver interesse na entidade que lhe confira influência significativa sobre tal entidade; (iii) tiver controle conjunto sobre a entidade; (iv) for coligada da entidade; (v) for joint venture (empreendimento conjunto) em que a entidade seja um investidor; (vi) for membro da administração da entidade ou de sua controladora; (vi) for membro próximo da família de membros da administração da entidade ou de seus controladores.

Nesse sentido, conforme a mesma norma, pode ser definido como transação com partes relacionadas a transferência de recursos, serviços ou obrigações entre partes relacionadas, independentemente de haver ou não um valor alocado à transação. 
As mais comuns e cotidianas transações entre partes relacionadas costumam envolver a compra e venda de bens e ativos, prestação de serviços de um modo geral, empréstimos, locações, cessão de uso de marcas, patentes e tecnologias, fornecimento de garantias, dentre outras contratações.

As transações com partes relacionadas são uma característica normal do comércio e dos negócios. Todavia, conforme a supra citada norma, o relacionamento com partes relacionadas pode interferir nos resultados e na posição financeira das entidades, uma vez que as partes relacionadas podem efetuar transações que partes não relacionadas normalmente não realizariam. Em outras palavras, as transações entre partes relacionadas podem não ser feitas pelos mesmos valores que são transacionados entre partes não relacionadas.

Por exemplo, uma entidade poderá vender bens à sua controladora por um valor próximo ao custo de produção, mas não vender nessas condições a outro cliente. Nessas circunstâncias, se tal contratação fosse levada à aprovação da assembleia geral de acionistas, a controladora estaria impedida de votar por estar sendo beneficiada particularmente com a transação?

A Comissão de Valores Mobiliários já analisou casos envolvendo benefício particular em transações com partes relacionadas. Nesse sentido, destacam-se o CASO TELE SUL PARTICIPAÇÕES S/A (Inquérito Administrativo CVM no TA/RJ 2001/4977) e o CASO PREVI-SISTEL (Inquérito Administrativo CVM no TA/RJ 2002/1153).

O CASO TELE SUL PARTICIPAÇÕES foi o primeiro caso que se tem notícia a abordar, no âmbito da CVM, a existência de conflito de interesses e/ou benefício particular em operações societárias.

Neste caso, foi realizada, em 25/04/2000, assembleia geral extraordinária da CTMR Celular S/A, no âmbito da qual foi aprovado, por unanimidade dos acionistas presentes, inclusive com o voto do acionista controlador, a Tele Celular Sul Participações S/A, 
o pagamento de $1 \%$ (um por cento) da receita líquida da CTMR Celular, à Telecom Italia Mobile, sua controladora indireta, a título de royalties pelo uso da marca TIM.

Por entender que a Tele Celular Sul Participações não poderia ter votado a respeito desse assunto, a Superintendência de Relações com Empresas (SEP), área técnica da CVM responsável pela coordenação, supervisão e fiscalização do cumprimento de normas aplicadas às companhias abertas, propôs a instauração de termo de acusação por eventual abuso de poder e conflito de interesses.

O Colegiado da CVM, por maioria de votos, em reunião realizada em 10.07.2001, condenou a Tele Celular Sul Participações e seu representante legal por infração ao disposto no artigo 115 e parágrafo $1^{\circ}$ da Lei $n^{\circ} 6.404 / 76$. Naquela oportunidade, a CVM decidiu que a Tele Sul Celular estava impedida de votar, por conflito de interesses, reconhecendo-se que o conflito de interesses impede o acionista conflitado de votar, independentemente de qualquer outra situação $^{182}$.

Todavia, muito embora o colegiado da CVM tenha reconhecido a existência de conflito de interesses, o voto proferido pelo Diretor Luiz Antonio Campos foi no sentido de que o acionista controlador não está, verdadeiramente, impedido de votar na assembleia que

\footnotetext{
182 Veja-se alguns trechos do voto vencedor, proferido pela Diretora Norma Parente: O fato de o controlador não votar propiciaria, sem dúvida, maiores discussões sobre a matéria, mais transparência e maior interesse dos demais acionistas, evitando, assim, questionamentos futuros. Que interesse teriam os acionistas minoritários em participar das discussões se antecipadamente já sabiam que o contrato seria inevitavelmente aprovado? Por outro lado, que interesse teria o controlador em apresentar as razões que justificassem a celebração do contrato se não há necessidade do apoio dos minoritários? É por isso que deve ser ressaltada a importância das decisões assembleares que não podem ser utilizadas como instrumentos destinados a legitimar a vontade do controlador ou ao cumprimento de meras formalidades. Neste caso, é indiferente realizá-las ou não, pois, na prática, pouco representam. O melhor, talvez, seria, até, que não fossem realizadas.[...]Não é verdade que o acionista só deve se abster de votar quando o seu interesse particular implicar no sacrifício do interesse da sociedade. Também não é verdade que, para caracterizar o conflito de interesses e impedir o voto do acionista controlador, há que se comprovar o benefício singular do controlador em detrimento da companhia ou demais acionistas [...]. $O$ conflito de interesses, na verdade, se estabelece na medida em que o acionista não apenas tem interesse direto no negócio da companhia mas também interesse próprio no negócio que independe de sua condição de acionista por figurar na contraparte do negócio. Não precisa o conflito ser divergente ou oposto ou que haja vantagem para um e prejuízo para o outro. A lei emprega a palavra conflito em sentido lato abrangendo qualquer situação em que o acionista estiver negociando com a sociedade.
} 
delibera sobre um contrato a ser celebrado entre ele e a companhia, pois essa não seria uma questão que pudesse ser decidida a priori, antes do voto do acionista ${ }^{183}$.

Por fim, vale registrar que o Diretor Marcelo Trindade votou pelo impedimento de voto da Tele Sul Celular não por entender existente o conflito de interesses, mas sim o benefício particular.

$\mathrm{Na}$ visão do ilustre diretor, o legislador quis conferir ao instituto do benefício particular uma acepção mais ampla em relação às demais hipóteses de impedimento de voto constantes no parágrafo primeiro do artigo 115 da Lei $n^{\circ}$ 6.404/76. Assim, segundo seu entendimento, independentemente do fato de existir um conflito entre o interesse particular do acionista e o interesse social, o impedimento de voto deve ser fazer presente na mera hipótese de existência desse interesse pessoal do acionista, que, não necessariamente, precisar ser vinculado ao status socci.

No caso em comento, defendeu então o Direto Marcelo Trindade que o benefício particular estaria atrelado à contraprestação auferida pelo acionista controlador em razão da contratação com a companhia. Em suas palavras:

“ [...] tratando-se de contrato entre o acionista e a companhia, a hipótese é de benefício particular, e não de conflito de interesses genericamente considerado - dado também entender que tal conflito deva ser apreciado ex post. Na verdade, embora a doutrina sempre considere o benefício particular a que se refere $o \S 1^{\circ}$ do art. 115 como um benefício na qualidade

183 Confira-se trechos do voto vencido: "Todavia, em alguns casos - restritíssimos por definição e muito específicos - a Lei $n^{\circ} 6.404 / 76$ permite que o direito de voto possa ser retirado do acionista. Noutros casos, porém, a Lei $n^{\circ}$ 6.404/76 permite que o acionista profira seu voto, mas se constatar que o acionista deixou de cumprir com o seu dever, impinge-lhe a coima de ilegalidade, permitindo a sua desconstituição.

Há, portanto, uma espécie de recomendação expressa ao acionista que se atenha ao interesse social. Tal é, em minha opinião, a hipótese do voto por acionista interessado, em aparente conflito de interesse.

E isso porque não é certo, nem muito menos garantido, que o acionista faltará com o seu dever perante os demais acionistas e a própria companhia para, com o voto, tirar proveito próprio e indevido.

Nesse sentido, permite-se ao acionista votar, na suposição de que ele não faltará com os deveres que lhe são impostos no artigo 115, caput, e no artigo 116, parágrafo único, na hipótese de ser acionista controlador; mas comprovado, por ligeiramente que seja, que este faltou com o seu dever, seu voto será tido como ilegal e a deliberação poderá ser anulada, se este voto tiver sido determinante para a formação da maioria necessária à validade da deliberação. 
de acionista, tal assertiva parece irrealistica, dado que a própria lei, dentre os direitos essenciais dos acionistas, inclui o de serem tratados de maneira idêntica, quando detentores da mesma espécie e classe de ações. Tal regra levaria quase sempre à nulidade da deliberação assemblear que pretendesse conferir direitos especiais a certos acionistas, independentemente da discussão sobre o impedimento de voto. A mim me parece que, embora tratando de benefício particular, quis a lei extremar uma hipótese mais ampla que as anteriores, porém ainda previamente perceptível, de conflito de interesses, a qual ocorre sempre que se possa atestar prévia $e$ induvidosamente que a deliberação trará benefício ao acionista, não extensivel aos demais, ou à companhia. Por isso entendo que na deliberação sobre a celebração de um contrato bilateral entre a companhia e o acionista está previamente impedido o voto deste último, não porque enxergue necessariamente no contrato um conflito de interesses - interesses que, aliás, normalmente convergem -, mas porque nele vejo um benefício particular (a contraprestação), benefício este que, concedido ao acionista contratante, não é estendido aos demais acionistas, por razões óbvias."

O Relator Luiz Antonio Campos consignou posição divergente em relação ao voto de Marcelo Trindade, defendendo que o conceito de benefício particular deve ser interpretado restritivamente, devendo ser entendido como a vantagem exclusiva auferida por um acionista em decorrência de sua posição de acionista, que rompe a igualdade existente entre seus pares. Assim, a contraprestação de uma contratação não poderia ser considerada como um benefício particular, uma vez que o valor que este acionista receberá nada mais seria do que a contrapartida pela prestação do objeto do contrato.

"O ilustre Diretor Marcelo Trindade, a seu turno, muito embora tenha afastado a proibição do voto por conflito de interesse no caso, entende que o voto não poderia ter sido proferido em decorrência de suposto benefício particular. Data venia, sou também obrigado a divergir. [...] Como é de correntia sabença, as normas restritivas de direito devem ser assim interpretadas; que dirá aquela que retira um direito fundamental das ações ordinárias que é o direito de voto. Não pode, portanto, ser alargado este conceito para restringir direitos de terceiros não amparados pela norma.Não obstante ser irrelevante para a solução da questão, porque, como se viu, não há benefício particular do acionista votante, também entendo que a hipótese não seria de benefício particular independentemente da estrutura societária.[...] o conceito de benefício particular está ligado diretamente ao conceito de igualdade entre os acionistas, ou seja, tudo aquilo que dê um tratamento aos acionistas - enquanto acionistas, é bom que se frise - diferente do que está geralmente disponível aos demais 
acionistas pode representar uma vantagem ou um benefício particular. Rompida esta igualdade, poderia haver um benefício particular. A esse respeito, bem notou Erasmo Valladão Azevedo e Novaes França, ao explicitar que:"Nesse passo porém o legislador não teve em mente os benefícios ou vantagens indevidos, de caráter extra-social, de que cuida o parágrafo 243, inciso 2, da Lei Acionária Alemã, mas benefícios perfeitamente lícitos, que a lei permite sejam atribuídos aos acionistas." (ob. cit. pág. 90 - grifou-se). Dito de outra forma, a questão do benefício particular, da vantagem, decorre do tratamento do acionista na qualidade de acionista, e não em outra situação em que eventualmente se encontre o acionista, pois, nesta hipótese, parece-me se enquadrar o conflito de interesses. Tal, a meu ver, não se confunde, contudo, com o pagamento de uma contraprestação ou do exercício de um direito de acionista pelo acionista. Assim é que o pagamento ao acionista relativamente a um contrato não rompe essa igualdade, uma vez que o valor que este acionista receberá será a contraprestação do objeto do contrato. Não recebe ele este valor por ser acionista, nem celebra ele o contrato por ser acionista. $O$ ponto central parece-me ser que aqueles que se encontram na mesma situação jurídica perante a companhia, na qualidade de acionista, devem ser tratados igualmente. No caso específico, parece-me não haver tal violação."

O benefício particular foi novamente mencionando em casos envolvendo transações com partes relacionadas no CASO PREVI-SISTEL (IA RJ TA 2002/1153). Nesse caso, foi realizada Assembleia Geral Extraordinária da Tele Norte Leste Participações S/A, em 30.11.99, na qual os acionistas aprovaram Contrato de Prestação de Serviços Gerenciais, a ser celebrado entre a Telemar Participações S/A, sua controladora, e as companhias concessionárias.

Segundo o relatório, a aprovação se deu com os votos da Previ, da Sistel e dos Fundos Mútuos de Investimento em Ações - Carteira Livre I e Carteira Livre BB Guanabara, dos quais a Previ e a Sistel eram os únicos cotistas. Ambas detinham, em conjunto, 77,84\% do capital do fundo FCF, controlador da Fiago Participações S/A, que, por sua vez, possuia 19,90\% do capital da Tele Norte Leste Participações S/A. Considerada individualmente, a Fiago era a sua maior acionista. 
Ainda conforme o relatório, em função de participação indireta na Tele Norte Leste Participações S/A, através da Fiago Participações S/A, a SEP/CVM identificou um possível conflito de interesses nos votos dos representantes da Previ e da Sistel, tendo em vista que para elas a contratação teria um impacto menor do que para os demais acionistas e a deliberação não seria aprovada sem os seus votos e dos fundos por elas controlados.

Na sessão de julgamento, o colegiado da Comissão de Valores Mobiliários, por maioria de votos, absolveu a Previ e a Sistel, por entender que o voto poderia ter sido exercido por ambas, já que a caracterização do conflito de interesses apenas pode ser verificada após a deliberação, abraçando, portanto, a tese do conflito material de interesses, conforme brevemente explanado no capítulo anterior ${ }^{184}$.

Entretanto, muito embora a análise da questão tenha se dado precipuamente sob a ótica do conflito de interesses, a existência do benefício particular foi novamente aventada, desta vez pela Diretora Norma Parente, a qual, corroborando a posição anterior do Relator

\footnotetext{
184 Tais foram os argumentos do voto vencedor: "Por todas estas razões acima expostas é que entendo que, no caso, não está, pelo menos por ora, comprovada a ocorrência de conflito de interesses, nem que o contrato aprovado seria lesivo ao interesse social. De fato, o voto da Diretora Relatora expressamente reconhece que não faz qualquer juízo de valor sobre a lesividade ou não dos votos proferidos ao interesse social.

Como dito, a meu ver, para entender que haveria proibição de voto e que, portanto, o voto proferido teria sido ilegal, a CVM deveria ter comprovado que efetivamente o interesse social havia sido sacrificado, e isso, com vantagem de estar falando já após os fatos. Tal prova não foi feita; dela não se desincumbiu a CVM, nem procurou fazê-lo; limitou-se a CVM ao terreno fácil da formalidade, afastando-se da substância, que penso ser essencial, razão pela qual não vejo fundamento jurídico para decidir contra os Defendentes". Importante mencionar que tal acórdão foi reformado pelo Conselho de Recursos do Sistema Financeiro Nacional, em janeiro de 2004. Na fundamentação do voto vencedor, o Conselheiro Edson Garcia entendeu que seria possível conciliar as duas teorias existentes (formal e material), para concluir que a avaliação do conflito pode ser feita a priori, pelo próprio acionista, ou a posteriori, quando, após o voto, outro acionista suscite a situação de conflito. Em sua palavras: "A interpretação mais adequada para a parte final do dispositivo em tela - que trata de benefício particular ou interesse conflitante - deve ser a que conclui que o voto do acionista que se considerar em conflito é vedado a priori, mas apenas no caso de esse acionista votante, em seu juízo de valor, se verificar na situação de conflito. Vale frisar: o acionista é quem deve julgar se está ou não na condição de conflito de interesse. Entretanto, adotou-se entendimento segundo o qual verificação da existência do conflito possa também se dar a posteriori. Na hipótese de não ter o acionista se visto na situação de conflito, até o momento do exercício de seu direito de voto, a seu talante deve votar na assembléia para que, em fase ulterior, seja apurada ocorrência ou não do conflito. Suscitada situação de conflito por outro acionista, deve o acionista questionado votar se, argüida sua situação de conflito, não vier a mudar sua posição anterior. Na hipótese de o acionista decidir por votar na assembléia em que foi argüida sua situação de conflito, ficará sujeito, além do posterior controle da situação de conflito, às cominações legais (imputação de responsabilidade e penalidades, inclusive pela Comissão de Valores Mobiliários”.
} 
Sampaio Campos no caso Tele Sul Celular, consignou que o conceito de benefício particular está atrelado a toda vantagem auferida por um acionista, em sua condição de acionista, não obtida pelos demais. Segundo a Diretora Norma Parente:

"Quando o legislador elege como uma das causas para a aplicação da proibição cautelar do exercício do voto o benefício particular tem por objetivo apenas impedir que o acionista seja agraciado com uma vantagem particular, como expressamente admitia o art. 40, IV, " $j$ ", do Decreto-Lei 2627/40. A noção de benefício particular é simples. Sempre que o acionista auferir um ganho, além daquele que os seus pares obtém, estará caracterizado o benefício particular. Ou seja, todos os titulares dos mesmos direitos estão em pé de igualdade na companhia. Na medida em que o acionista angaria um proveito diferente dos demais, recebe um benefício particular (v.g. atribuir "uma bonificação a determinado acionista por este ou aquele motivo", no dizer de Miranda Valverde). O benefício particular pressupõe, portanto, um ganho decorrente da própria condição de acionista. A sua aprovação requer um especial cuidado em face do art. 109 da lei $n^{o}$ 6.404, que determina a igualdade dos direitos de todos os acionistas."

Outros casos tratando de impedimento de voto em transações com partes relacionadas foram apreciados pela $\mathrm{CVM}^{185}$, sem, contudo, voltar a abordar o instituto do benefício particular, ficando a discussão adstrita à existência ou não do conflito de interesses e, por conseguinte, acerca de sua abordagem formal ou material, parecendo demonstrar que aquela Autarquia, acertadamente, teria superado a discussão relativa à aplicação do benefício particular em transações com partes relacionadas.

Entretanto, em 2010, o tema volta a ser enfrentando pela CVM. Com efeito, no CASO TRACTEBEL (Processo Administrativo $n^{\circ}$ RJ 2009-13179, julgado em 09 de setembro de 2010), a Tractebel Energia S/A formulou consulta à Comissão de Valores Mobiliários para confirmar o entendimento de que a sua acionista controladora (a GDF Suez Energy Latin America Participações Ltda) não estaria impedida de exercer o direito de voto na assembleia que iria deliberar sobre a aquisição, pela Tractebel, das ações emitidas pela Suez Energia Renovável S/A, até então detidas pela GDF, tendo em vista que os termos de referida

\footnotetext{
${ }^{185}$ Caso BID-BNP Paribás (IA CVM TA/RJ n ${ }^{\circ}$ 2002/2405).
} 
transação teriam sido negociados por comitê especial independente criado nos moldes do Parecer de Orientação n 35, de 2008 (“Parecer 35”).

O Colegiado, por maioria de votos, entendeu que a GDF estaria impedida de exercer o direito de voto na referida assembleia, independentemente da criação de comitê especial independente, nos termos Parecer 35, em razão da existência de conflito de interesses, voltando a adotar, assim, a tese formalista de reconhecimento de tal instituto ${ }^{186}$.

186 O Relator do caso, Diretor Alexsandro Broedel Lopes, levantou a possibilidade de se utilizar da terceira via de interpretação do instituto defendida por Fábio Konder Comparato, com a adoção de algumas soluções organizativas, expressão utilizada por Calixto Salomão Filho para tratar da adoção de medidas internas e práticas de governança corporativa, com o intuito de se diminuir as assimetrias de informação e outros custos de transação associados a operações com a existência de potencial conflito. No entanto, para o caso em concreto, acabou por reconhecer a existência do conflito de interesses ex ante, admitindo que a adoção de comitê independente não afastaria a vedação de voto contida no $\S 1^{\circ}$ do art. 115 da Lei n. 6.404/76, no que foi acompanhado pela então Presidente da Autarquia Maria Helena Santana e pelos Diretores Marcos Barbosa Pinto e Otávio Yazbek, restando vencido o Diretor Eli Loria, que manteve o entendimento sustentado anteriormente pela CVM de que o conflito de interesses apenas pode ser reconhecido ex post. Cite-se alguns trechos dos votos vencedores, no que tange a essa questão: 1) Trecho do voto proferido pelo Diretor Alexandre Broedel: Compartilho integralmente com a forma de interpretação do artigo 115 , parágrafo $1^{\circ}$, proposta por Comparato. Entendo que o conflito de interesses pode ser verificado tanto a priori, nos casos em que possa ser facilmente evidenciado, quanto a posteriori, nas situações em que não transpareça de maneira reluzente. É verdade que, como mencionado, um contrato entre a companhia e um acionista trará consigo, necessariamente, uma situação de conflito, natural da própria relação entre os contratantes. Mas, em tese, se o acionista, por intermédio de algum mecanismo de governança, fizer prova de que agirá de acordo com o interesse da companhia, o seu voto será possível, ainda que seja parte de contrato com a companhia. Com efeito, será sempre difícil verificar se a manifestação do acionista condiz, ou não, com o interesse social da companhia. Nesse aspecto, alguns dirão ser impossível a criação de mecanismos que assegurem, com altíssimo grau de certeza, a solução do problema do conflito, na manifestação do voto. Dirão que conflito nunca poderá ser resolvido, ex ante, por medidas acautelatórias tomadas pela própria companhia, em atos de melhor governança. Acredito, no entanto, que o estudo constante do assunto, das evoluções nos arranjos negociais do mercado, poderá, ao menos em tese, trazer uma solução para o problema ora em debate. Não podemos afirmar que o conflito de interesses não poderá ser resolvido, ex ante. Essa possibilidade precisa manter-se aberta. Se essa opinião corresponde a uma terceira corrente sobre o assunto ou se seria apenas um aperfeiçoamento da corrente formal, trata-se de um questionamento interessante. Meu entendimento é que essa visão está alinhada com alguns debates encontrados internacionalmente e encontra embasamento em pensamentos de alguns importantes doutrinadores, aqui citados. [....] Resumindo tudo que foi dito até o momento, o conflito de interesses, em maior ou menor grau, será inerente a uma situação que envolva contrato bilateral entre a companhia e o acionista. Portanto, nessas situações, presume-se que os acionistas contratantes não podem votar na assembleia geral que vá deliberar sobre o contrato de que são parte. [...] A solução proposta pode, potencialmente, mitigar o conflito de interesses. Deve ser considerada, ainda, um ato de governança válido, até porque em linha com o que dispõe o Parecer CVM $n^{\circ} 35$. Deve-se frisar, porém, que o próprio Parecer CVM $n^{\circ} 35$ deixa expresso que a sua aplicação é direcionada, especificamente, para a hipótese do artigo 264 da Lei $n^{\circ}$ 6.404, de 1976, que "criou um regime especial para as operações de fusão, incorporação e incorporação de ações envolvendo a sociedade controladora e suas controladas ou sociedades sob controle comum", caso em que o controlador pode, via de regra, exercer seu direito de voto. Portanto, a situação prevista no Parecer não excepciona, em absoluto, a previsão do parágrafo $1^{\circ}$ do artigo 115 , ora em análise. Assim, não obstante os esforços empreendidos, entendo que o Comitê proposto pela Tractebel não elimina, de maneira efetiva, o problema do conflito de interesses, razão pela qual não vejo a medida como suficiente para superar a proibição de voto prevista no parágrafo $1^{o}$ do artigo 115 da Lei 6.404/76. 2) Trecho do 
voto proferido pela Diretora Maria Helena de Santana: Nesse ponto, a controvérsia diz respeito ao que seja 'interesse conflitante com o da companhia' e a discussão está polarizada em torno de duas posições: de um lado, os defensores do chamado conflito formal, e, de outro lado, os que crêem que o conflito é substancial. Em última análise, a questão está em saber se é caso de impedimento de voto que se verifica antes da deliberação, quando o acionista nela tiver um interesse conflitante com o dos demais acionistas, por ser particular a ele, ou de modalidade ilícita de exercício do direito de voto, cujo exame só pode ser feito posteriormente à deliberação, já que só se configura quando o acionista tiver, por força de interesse irreconciliável com o da companhia, ocasionado prejuízos a ela.

Essa última posição parece-me, contudo, pouco convincente, por duas razões, pelo menos. Em primeiro lugar, ao exigir para sua configuração a verificação do prejuízo à companhia, ela faz do conflito de interesses um conceito jurídico ocioso, dispensável frente à proibição geral ao abuso de direito de voto, prevista no caput do art. 115. Com efeito, se o voto exercido com o fim de causar dano à companhia já é sancionado pela lei em razão do seu caráter abusivo, seria totalmente supérflua a previsão, no $\S 1^{o}$ desse dispositivo, de um conflito de interesses que, do mesmo modo, só se configuraria quando identificado o prejuízo ao interesse social. Se assim fosse, a lei teria consagrado unicamente a proibição do abuso de direito de voto. Por essa razão, uma tal interpretação, que atribui ao legislador palavras inúteis, me parece pouco coerente.3) Trecho do voto proferido pelo Diretor Marcos Barbosa: Não posso concordar com a tese de que não há conflito de interesses e, portanto, impedimento prévio de voto por parte do acionista em vias de deliberar sobre um contrato entre ele e a companhia. Não posso concordar com essa tese porque ela é incompatível com o texto da lei. $O \$^{\circ}$ do art. 115 não diz que, nas situações de conflito de interesses, o acionista deve votar no interesse da companhia; ele diz que, nessas situações, "o acionista não poderá votar". Pessoalmente, não vejo como sustentar que o acionista pode votar quando a lei diz expressamente que ele não pode. Toda interpretação encontra um limite; e eu não consigo ir além desse. [Se assim não fosse] Qual seria então a função da proibição de voto em casos de conflito de interesse? Por que a lei se importou em dizer que o acionista "não pode votar" se não existem situações práticas em que essa proibição se aplica? Mais ainda: Qual a diferença entre o impedimento de voto, previsto no $\$ 1^{\circ}$ do art. 115 , e o abuso de direito de voto, previsto no caput do mesmo artigo? Esse último ponto merece destaque. O caput do art. 115 diz expressamente que "o acionista deve votar no interesse da companhia"; caso não o faça, seu voto será considerado abusivo. Se o conflito de interesses só pudesse ser apurado depois da deliberação, o $\$ 1^{\circ}$ do art. 115 não faria sentido algum; ele nada acrescentaria ao caput do artigo. Esse não foi, obviamente, o propósito da lei, que se propôs a tratar de maneira distinta as duas situações, o abuso de voto e o conflito de interesses, como denota o próprio título do artigo em questão. Mas o principal e cabal argumento contra a tese do controle a posteriori dos casos de conflito de interesses não está nos aspectos apontados acima. $O$ principal argumento é funcional. $O \$ 1^{\circ}$ do art. 115 existe para evitar que a companhia sofra prejuízos em situações nas quais é grande o risco de que o acionista venha atuar em benefício próprio. Deixando o acionista votar, ignora-se esse risco e abre-se espaço para que ocorra justamente o que a lei procurou evitar. Esse risco é tanto maior, a meu ver, num país como o nosso, em que as demandas judiciais ainda são extremamente lentas. Aqui, ações propostas para responsabilizar acionistas controladores demoram anos, senão décadas. Além disso, elas encontram um judiciário pouco preparado para julgar causas de direito societário. Portanto, no Brasil mais do que em qualquer lugar do mundo, a proibição de voto é fundamental nos casos de conflito de interesses. 4) Trecho do voto proferido pelo Diretor Otavio Yazbek: É bem verdade que o voto dado em situação de conflito pode tender à abusividade, com o acionista colocando na balança os interesses que pode vir a privilegiar. Como também é possível que isso não ocorra. $O \$ 1^{\circ}$ do art. 115 destina-se, a meu ver, a criar mecanismo de proteção à sociedade contra o risco daquele abuso, que de outra maneira seria dificilmente identificável. Trata-se, assim, de regra de natureza precaucionária. Se, no Código Civil italiano, havia aquela vedação geral, acompanhada de um segundo período que relativizava os seus efeitos, a solução da lei brasileira me parece mais complexa. A regra geral quanto ao conteúdo do voto ("... exercer o direito de voto no interesse da companhia"), assim como a caracterização de sua abusividade, encontram-se no caput do art. 115 . O $\$ 1^{\circ}$, por sua vez, tem objeto próprio, destinando-se a trazer vedações às vezes mais e às vezes menos específicas ao exercício do poder de voto. Por mais que se possa criticar a técnica legislativa adotada nos dispositivos em comento, não me parece possível considerar que, dentro de um mesmo dispositivo legal, iniciado com uma vedação ("O acionista não poderá votar..."), se encontram situações tão diversas, a saber: três hipóteses de proibição de voto (duas delas de cunho mais objetivo) e uma de mero princípio (que seria redundante em relação ao caput do artigo, aliás) ou de controle posterior, isso sem nenhuma qualificação ou diferenciação. Creio, assim, que a única solução 
No entanto, mais do que alterar o posicionamento da Autarquia acerca do instituto do conflito de interesses, o Colegiado novamente chegou a abordar a aplicação do instituto do benefício particular em transações com partes relacionadas.

Com efeito, a Presidente Maria Helena Santana defendeu que ainda que fosse discutível a configuração do conflito de interesses, o acionista controlador estaria impedido de votar pela existência do benefício particular o qual, ao contrário da argumentação doutrinária a respeito do assunto, não deveria ser interpretado restritivamente como sendo apenas aquela vantagem obtida pelo acionista enquanto tal, que romperia a igualdade entre os demais, mas da forma mais ampla possível, retomando o entendimento do então Presidente Marcelo Trindade no Caso Tele Sul Participações, acima citado, sob pena de se adotar interpretação vazia de qualquer utilidade prática ${ }^{187}$.

logicamente possivel é o reconhecimento de que existe efetiva vedação ao voto também no caso dos conflitos de interesses referidos na parte final do $\S 1^{\circ}$ do art. 115.

${ }^{187}$ A seguir, trecho do voto da então Presidente Maria Helena Santana nesse sentido: A questão, como se sabe, é das mais controvertidas tanto na doutrina como na jurisprudência desta Autarquia, tendo o Colegiado, em oportunidades diversas, adotado posições divergentes sobre o tema. Em breve síntese, a discussão se dá a respeito de dois aspectos da interpretação do disposto no $\S 1^{\circ}$ do art. 115. Primeiro, embora prepondere na CVM o entendimento de que, no caso de deliberação que possa beneficiar o acionista 'de modo particular', o conflito deve ser examinado antes da deliberação, bastando, para sua configuração, a identificação do benefício particular a ser revertido em favor do acionista, há controvérsia quanto à extensão dessa hipótese. Discute-se, a propósito, se ela se restringe ao benefício particular recebido pelo acionista, na sua qualidade de acionista, que rompe a igualdade entre os sócios, ou se abrange qualquer benefício a ser concedido por conta da deliberação, ao acionista, que não seja extensível aos demais.

Nesse ponto, parece-me mais acertada a segunda posição, pelas mesmas razões que foram manifestadas pelo ExPresidente Marcelo Trindade em seu voto no julgamento do Inquérito Administrativo RJ2001/4977. Com efeito, sob pena de se adotar uma interpretação vazia de utilidade prática e em descompasso com a atual realidade das companhias abertas, entendo que o acionista está impedido de votar toda vez que da deliberação possa resultar a seu favor um benefício particular, ou seja, que não seja extensível aos demais acionistas. Daí decorre, como conseqüência inevitável, que o acionista controlador está (previamente) impedido de votar na deliberação de assembleia destinada a aprovar a celebração de contrato bilateral em que figura como contraparte, pois a contraprestação a ser recebida por força do contrato constitui um benefício particular, que, não há dúvida, não é compartilhado com os demais acionistas. [...] Uma vez esclarecido, como visto, que essa deliberação beneficia o acionista de modo particular, em razão da vantagem consubstanciada na contraprestação, e ainda que ele tem interesse conflitante com o da companhia, em virtude de ser sua contraparte na transação, não consigo aceitar que a atuação do comitê independente possa afastar a incidência das hipóteses legais de impedimento de voto. Com efeito, mesmo admitindo-se que a atuação do comitê tenha assegurado condições comutativas à transação- 
Tal posição foi acompanhada pelo Diretor Marcos Barbosa $^{188}$, mas não pelo Diretor Otávio Yazbek, que entende que o benefício particular é a vantagem exclusiva que implica no rompimento da igualdade dos acionistas enquanto tais, defendendo também que o fato que o diferencia do instituto do conflito de interesses não é a licitude ou ilicitude da vantagem, mas a espécie de vantagem, que, no caso do benefício particular sempre é inerente à qualidade de acionista, enquanto que no conflito de interesse a vantagem pode estar associada à relação jurídica diversa da societária ${ }^{189}$.

o que, penso, só poderia ser atestado em cada caso concreto - o benefício particular e o interesse conflitante ainda estariam presentes, ante o fato de que o acionista controlador é a contraparte da companhia na transação.

${ }^{188}$ Cite-se trecho do voto do Diretor Marcos Pinto Barbosa: Durante muito tempo, entendeu-se que a hipótese de impedimento de voto por benefício particular, prevista no art. $115, \S 1^{\circ}$, aplicar-se-ia apenas às vantagens concedidas aos acionistas enquanto sócios da companhia. Todavia, conforme ressaltei no Caso Duratex, essa posição não encontra amparo na Lei $n^{\circ} 6.404$, de 1976. Quando a lei impede o acionista de votar em situações "que puderem beneficiá-lo de modo particular", sua hipótese de incidência não se restringe às vantagens recebidas pelo acionista enquanto sócio. Seu campo de aplicação é muito mais amplo, alcançando qualquer vantagem de que goze apenas um acionista. Um contrato entre o acionista e a companhia faz justamente isso: ele beneficia o acionista contratante de modo singular.

${ }^{189}$ Cite-se trecho do voto do Diretor Otávio Yazbek: Antes de passar ao caso concreto, porém, gostaria de antecipar também uma posição em relação a uma questão diretamente relacionada às acima tratadas, que é a do benefício particular. Esse tratamento é importante não apenas porque o tema foi tratado nos votos da Presidente e do Diretor Marcos Barbosa Pinto, mas também porque, a meu ver, ela melhor delimita toda a discussão acima. Começo, aqui, por registrar a minha discordância em relação aos votos da Presidente e do Diretor Marcos Barbosa Pinto no que tange à existência, no presente caso, de benefício particular (a terceira hipótese de impedimento do $\S 1^{\circ}$ do art. 115 da Lei). Para mim, que neste ponto acompanho, ao menos em parte, as considerações de Erasmo Valladão e do ex-Diretor Luis Antônio de Sampaio Campos, já anteriormente referidas[20], benefício particular é aquele que decorre do rompimento da relação de igualdade dos acionistas enquanto tais. É aquilo que cria diferenciações onde não há nenhum outro fundamento jurídico (que não o da condição de acionista) que as possa justificar. Remeto aqui, como exemplo, ao Processo RJ 2009/5811, em que se tratou da incorporação da Duratex S.A. pela Satipel Industrial S.A. Naquela ocasião, embora eu tenha votado pela impossibilidade de realização da operação nos termos em que proposta, com a fixação de relações de troca distintas para as ações detidas pelo controlador e pelos minoritários, acabei por ressalvar que, caso a estrutura proposta fosse válida (e, em conseqüência, a operação fosse factível), se estaria diante de um caso de benefício particular. E isso justamente porque, naquele caso, os acionistas seriam diferenciados apenas em razão da sua situação de acionistas. Ora, na relação que aqui se discute, o acionista controlador figura como alienante de um determinado bem, em relação contratual autônoma, motivo pelo qual ele pode ser considerado parte interessada na conclusão daquele contrato. Mas os benefícios que ele obteria daquele contrato não teriam sido propriamente subtraídos à coletividade dos demais acionistas. Compreendo que conflito de interesses e benefícios particulares sejam categorias que se misturam em alguma medida e que essa confusão, talvez também esteja relacionada ao processo pelo qual, no Brasil, progressivamente, se esvaziou a vedação do voto em caso de conflito de interesses. Mas, uma vez afastado aquele esvaziamento, não há porque manter as duas esferas indiferenciadas. Neste ponto, aliás, também quero deixar registrada uma discordância em relação às posições do Professor Erasmo Valladão sobre o tema. Isso porque, em razão de sua interpretação acerca do conflito de interesses, ele acaba por diferenciar benefício privado de conflito de interesses asseverando que o primeiro consistiria em uma vantagem 
Percebe-se, assim, pela análise dos casos apresentados, que a aplicação do instituto do benefício particular em transações com partes relacionadas não vem sendo tratado de modo pacífico pela CVM, não sendo demais afirmar a existência de certa instabilidade no posicionamento externado pela Autarquia.

De fato, no Caso Tele Sul Participações, o Diretor Marcelo Trindade defende que o instituto deve ser interpretado extensivamente, de modo a abranger toda a vantagem obtida por determinado acionista, seja qual for a situação, concluindo que, no caso de transações com partes relacionadas, a vantagem seria correspondente à contraprestação do contrato firmado com a companhia. No âmbito do mesmo caso, o Diretor Luiz Antônio Sampaio Campos defende que o instituto deve ser interpretado restritivamente, devendo ser caracterizado

lícita, enquanto o segundo envolveria vantagens ilícitas. Com todo o respeito pela posição do autor, não vejo como concordar com ela. Pelo que se pode depreender da análise do referido autor, conflito de interesses corresponderia a vantagens ilícitas em razão justamente da equiparação, essencial para a sua análise, entre voto dado sob conflito e voto abusivo. Se essa correlação apresenta razoabilidade ante o entendimento adotado na discussão daquele tema, porém, não me parece que o mesmo valha plenamente para a presente discussãoaquele conceito de conflito, se extrapolado, geraria aqui uma incongruência. Isso porque ainda que se siga a linha de que conflitos apenas podem ser identificados ao produzirem efeitos (quando do reconhecimento da ilicitude dos seus resultados, portanto), isso não autorizaria dizer que um conflito só existe quando aquele efeito danoso tenha se produzido. O conflito já existia antes, os interesses contrapostos já existiam - difícil era a sua identificação. Indo além, dizer que conflitos de interesses correspondem a vantagens ilícitas, neste contexto que ora descrevo, equivaleria a dizer que qualquer contratação realizada quando havia aquele tipo de contraposição seria, também, ilegal. Ora, tanto não há ilicitude nas contratações que, como já exposto, a Lei não proíbe relações em que interesses contrários estejam envolvidos. Em suma, nos casos de posições contratuais contrapostas entre acionista e sociedade (e uma vez afastada a hipótese do benefício particular), muitas vezes podem existir interesses contrapostos (ou seja, o conflito de interesses propriamente dito). Nem por isso há, aí, ilicitude. Entendo que equiparar o interesse existente em caso de conflito de interesses a interesse ilícito, assim, gera uma dificuldade insolúvel. Tanto assim que, para mim, o que a Lei cria, ao lidar com os conflitos de interesses, é um regime protetivo da integridade da formação de vontade da sociedade. Ilicitude, reitero, decorreria apenas da abusividade do voto propriamente dita, da obtenção daqueles efeitos vedados por lei, estes sim muito provavelmente apenas apuráveis em momento posterior. Neste sentido, e apenas para fazer uma síntese, entendo que benefício particular e conflito de interesses distinguem-se porque, no primeiro caso, se está tratando de vantagens que diferenciam os acionistas exclusivamente na qualidade de acionistas. Já no segundo, os envolvidos podem figurar sob outro manto, como partes contratantes, por exemplo. A confusão entre as duas categorias talvez esteja relacionada não apenas aos debates acima referidos, mas também ao fato de que, em ambos os casos, no fundo, talvez se esteja falando em conflito de interesses em sentido amplo.Nas duas situações, porém, não vejo como se poderia falar, a priori, em ilicitude da vantagem perseguida em si - ilicitude está diretamente relacionada à abusividade do voto dado, não ao interesse que o acionista próprio do acionista, que esse gostaria de perseguir. De qualquer maneira, realço que não vejo, neste caso, benefício particular propriamente dito. 
somente como a vantagem obtida pelo acionista enquanto tal, que rompe a igualdade existente entre o acionista beneficiado e os demais, não podendo corresponder à contraprestação de um contrato.

No Caso Previ-Sistel, a Diretora Norma Parente adotou entendimento semelhante ao exposto pelo Diretor Luiz Antônio Sampaio Campos no Caso Tele Sul Participações, valendo consignar que, posteriormente, fez questão de assumir sua mudança de entendimento, passando a defender que o benefício particular deveria ter uma interpretação mais ampla ${ }^{190}$.

Por fim, no Caso Tractebel, a CVM, por meio de Sua Presidente Maria Helena de Santana e de seu Diretor Marcos Barbosa, volta a se apoiar na tese defendida pelo Diretor Marcelo Trindade no Caso Tele Sul Participações, com a discordância do Diretor Otávio Yazbek.

Essa instabilidade de posicionamento externada pela Autarquia não é nada salutar ao mercado, gerando grande insegurança jurídica aos operadores de direito: afinal, o benefício particular deve ou não ser aplicado em operações com partes relacionadas?

Não parece ser correta a aplicação. Isso porque, considerando os aspectos conceituais do instituto do benefício particular, conforme exposto no capitulo inaugural, não se pode afirmar que a vantagem eventualmente obtida pelo acionista em transações com partes relacionadas configura-se, tecnicamente, como um benefício particular.

De início, há que se constatar que não está presente na vantagem obtida pelo acionista nas transações com partes relacionadas o conceito de liberalidade, uma vez que a contraprestação ao acionista não advém gratuitamente, mas como decorrência do cumprimento da obrigação contratada. Em outras palavras, se o acionista firma um contrato de mútuo com sua sociedade, os juros por ele recebidos não podem ser considerados como prestação gratuita,

\footnotetext{
${ }^{190}$ Nas palavras da Diretora Norma Parente, "embora tenha admitido que benefício particular concernia apenas àqueles benefícios diretamente ligados à condição de acionista, hoje entendo, como o então Diretor Marcelo Trindade, atual Presidente desta CVM, que benefício particular deve ter uma extensão mais ampla".
} 
de caráter liberal, vez que decorrente da disponibilização dos recursos pelo acionista a sua sociedade.

E, como bem afirmado pela doutrina francesa, retirar parcela da riqueza social correspondente à prestação disponibilizada à companhia não é benefício particular, haja vista que não pode haver vantagem em relações equitativas, no qual uma parte não recebe mais do que dá: “Allors, Il n’y a pas avantage mais prestations équilibrées".

E mesmo que se admita que as taxas de juros contratadas não são comutativas, recebendo o acionista uma contraprestação superior em comparação àquilo que se disponibilizou à sociedade, ainda não se estaria diante do benefício particular, já que a vantagem obtida pelo acionista com a transação deixaria de ser lícita, por prejudicar a companhia. Nos dizeres da Lei Acionária Brasileira, nessas circunstâncias, restaria configurada a "vantagem a que não faz jus", justificando-se falar na existência de conflito de interesses ou exercício abusivo do voto, mas não em benefício particular, que apenas prevê a vantagem lícita.

No mais, a vantagem obtida pelo acionista com a contratação com sua sociedade não é inerente a sua qualidade de sócio, mas de credor, não sendo correto afirmar, por essa razão, que teria o condão de romper a igualdade existente entre os demais acionistas.

Assim, por restar ausente, no mínimo, os elementos concernentes à liberalidade e à vinculação ao status socci, não poderá a eventual vantagem obtida pelo acionista em transações com partes relacionadas ser considerada como benefício particular, nos termos do $\S 1^{\circ}$ do artigo 115 da Lei $n^{\circ} 6.404 / 76$. 


\subsection{Operações de Incorporação de Ações de Companhias Controladas ou sob Controle Comum e o Parecer de Orientação CVM n 34}

Antes de se abordar os aspectos necessários à compreensão das operações de incorporação de ações de companhias controladas, cumpre traçar algumas linhas sobre as operações de incorporação de sociedades.

A incorporação de sociedades, de um modo geral, é uma das técnicas de reorganização societária previstas pelo ordenamento jurídico. Pode ser definida, nos termos do artigo 227 da Lei $n^{\circ}$ 6.404/76, como a operação pela qual uma ou mais sociedades são absorvidas por outra, que lhes sucede em todos os direitos e obrigações.

O procedimento da incorporação envolve a negociação, pelas sociedades incorporadora e incorporada, dos termos e condições da operação, os quais ficarão consignados no instrumento denominado protocolo de incorporação. No protocolo de incorporação estará definido, inclusive, os critérios de avaliação do patrimônio da incorporada e a relação de substituição das ações a que ficarão sujeitos seus acionistas. Adicionalmente, conterá também os motivos e as justificativas da operação, nos termos do artigo 225 da Lei $6.404 / 76$.

Aprovado o laudo de avaliação e o protocolo de incorporação pela assembleia geral de acionistas da companhia incorporadora, será autorizado, por esse mesmo conclave, a realização do aumento de capital da companhia incorporadora, o qual será integralizado com a versão do patrimônio da incorporada, caso os acionistas dessa última também aprovem os termos do protocolo de incorporação.

Por conseguinte, os acionistas da companhia incorporada receberão ações da companhia incorporadora, em substituição às suas antigas ações da companhia incorporada, na proporção definida pela relação de troca celebrada pelas partes no protocolo de incorporação. Como resultado, opera-se a extinção da companhia incorporada e a sub-rogação da incorporadora em todos seus direitos e obrigações. 
A incorporação de ações, em termos procedimentais, é bastante semelhante com a incorporação de sociedades, conforme disposto no artigo 252 da Lei $n^{\circ}$ 6.404/76: as companhias têm que celebrar e aprovar, por meio de seus acionistas, os termos e condições do protoloco de incorporação, cabendo também à sociedade incorporadora aprovar o laudo de avaliação da companhia cujas ações serão incorporadas, para que as partes possam avençar a relação de substituição das ações.

A diferença consiste no fato de que na incorporação de ações não se opera a sucessão pela companhia incorporadora dos direitos e obrigações da companhia cujas ações serão incorporadas, simplesmente porque tal companhia não se extingue, tal como ocorre na incorporação de sociedades.

O principal efeito da incorporação de ações é a criação do que se denomina subsidiária integral $^{191}$, por meio da conferência compulsória de todas as ações emitidas pela companhia ao patrimônio da sociedade incorporadora, passando a ser, assim, a única titular das ações da companhia. Da mesma forma, os acionistas da companhia cujas ações foram incorporadas receberão, em substituição às suas antigas ações, novas ações emitidas pela companhia incorporadora, na proporção definida pela relação de troca celebrada pelas partes no protocolo de incorporação.

A incorporação de ações pode se dar no âmbito de sociedades controladas ou sob controle comum, conforme disposição do artigo 264 da Lei $n^{\circ}$ 6.404/76. Nesse caso, conforme exposto pela própria Exposição de Motivos da Lei $n^{\circ}$ 6.404/76, o legislador previu regras especiais para tal modalidade de incorporação em razão de inexistir duas maiorias distintas e independentes que pudessem defender de forma equitativa e os interesses das companhias envolvidas.

\footnotetext{
191 Segundo EIZIRIK, "A incorporação de ações constitui operação pela qual uma sociedade anônima é convertida em subsidiária integral de outra companhia brasileira, estando expressamente prevista no art. 252 da Lei 6.404/76". Incorporação de Ações: Aspectos Polêmicos. In: Ward Jr. Walfrido Jorge (Coord.). Fusão, Cisão, Incorporação e Temas Correlatos. São Paulo: Quartier Latin, 2009, p. 78. Por sua vez, entende-se por subsidiária integral a sociedade anônima cujas ações são detidas integralmente por outra companhia brasileira.
} 
Com efeito, na incorporação de ações de companhia controlada ou sob controle comum, o mesmo acionista controlador (que controla direta ou indiretamente a companhia incorporadora e direta ou indiretamente a companhia cujas ações serão incorporadas) tem o poder de decidir os termos e condições da incorporação, inclusive a relação de substituição das ações, o que poderia prejudicar interesses de acionistas minoritários. Para contornar esse potencial problema, o artigo 264 da Lei $\mathrm{n}^{\circ}$ 6.404/76 determina que os patrimônios de ambas as companhias envolvidas sejam avaliados a preços de mercado ou, no caso de companhias abertas, qualquer outro critério definido pela Comissão de Valores Mobiliários ${ }^{192}$.

Importante ressaltar, todavia, que a avaliação obrigatória prevista no mencionado artigo 264 não tem por função vincular a relação de substituição de ações a que os acionistas minoritários estarão submetidos ${ }^{193}$, mas somente fornecer um parâmetro de comparação com a avaliação definida no protocolo de incorporações e fixar o valor por ação para fins de eventual exercício do direito de recesso dos acionistas minoritários que não concordarem com a operação.

Deste modo, nos últimos anos tem sido bastante comum o questionamento de acionistas minoritários perante a CVM, pleiteando o impedimento de voto do acionista controlador em operação de incorporação de ações, mormente nos casos em que a relação de substituição definida implique em uma diluição de suas participações societárias. Nessas circunstâncias, os acionistas minoritários defendem que o aumento de participação do acionista controlador decorrente da incorporação de ações configura um benefício particular, à luz do artigo $115, \S 1^{\circ}$, da Lei $n^{\circ} 6.404 / 76$.

\footnotetext{
${ }^{192}$ No entender de ARAGÃO e LIMA, trata-se de mecanismo criado pelo legislador para "assegurar, de um lado, a prevalência do princípio majoritário e, de outro, tratamento equitativo aos acionistas minoritários". (cf. Incorporação de Controlada: a disciplina do art. 264 da Lei 6.404/76. In: Perin Jr., Écio et alli (Coord.). Direito Empresarial: aspectos atuais do direito empresarial brasileiro e comparado. São Paulo: Método, 2005, p. 349. 193 De fato, no entender de LEÃES, "a deliberação sobre a conveniência da operação continua a ser de competência discricionária da maioria acionária e, como tal, é inquestionável pela minoria" (cf. Incorporação de companhia controlada. Revista de Direito Mercantil, São Paulo: RT, v.94, abr-jun 1994, p.87-96.
} 
Diversos foram os casos discutidos na CVM que tratavam da existência do benefício particular em operação de incorporação de ações, culminando, inclusive, com a publicação de um parecer de orientação por essa autarquia, o Parecer de Orientação $n^{\circ}$ 34/2006, com vistas a impor maior segurança jurídica à questão.

O primeiro caso que se tem notícia a abordar o instituto do benefício particular em incorporação de ações foi o CASO AMBEV (Processo Administrativo Sancionador CVM RJ $n^{\circ}$ 2004/5494), consubstanciado em uma reestruturação societária envolvendo quatro sociedades: a Companhia de Bebidas das Américas S/A (“Ambev”), a sociedade Braco, holding controladora da Ambev, e a Labatt Brewing Canadá Holding Ltd. ("Labatt"), controlada pela Interbrew S/A ("Interbrew”).

Inicialmente foram emitidas 141.700 .000 (cento e quarenta e um milhões e setecentas mil) de ações da Interbrew, totalmente subscritas pela Braco, em troca da integralidade das ações de sua emissão. Dessa forma, os antigos controladores diretos da Interbrew passaram a controlar diretamente a Braco e, por conseguinte, indiretamente a Interbrew e a Ambev, por meio da Braco, constituindo-se, assim, no novo controlador do grupo. Posteriormente, a Labatt, até então controlada diretamente pela Interbrew, foi incorporada ao patrimônio da Ambev, resultando no aumento da participação societária indireta do novo controlador na Ambev, em detrimento dos acionistas minoritários.

Os acionistas minoritários alegam que a incorporação da Labatt pela Ambev fez parte do preço do negócio envolvendo a permuta de ações dos antigos controladores da Braco, servindo para compensar o valor a maior que foi atribuído às suas ações pelos antigos controladores da Interbrew. Em outras palavras, para compensar tal valor a maior, ficou acertado que a incorporação da Labatt ocorreria com a finalidade de aumentar a participação societária dos novos controladores na Ambev. 
Por essa razão, no entender dos acionistas minoritários, dentre outras irregularidades aventadas ${ }^{194}$, a incorporação de ações trouxe uma vantagem exclusiva aos controladores, decorrente do referido aumento de suas participações no capital social da Ambev, em detrimento dos demais acionistas.

Entretanto, pela análise dos votos proferidos pelos membros do colegiado da CVM à época, percebe-se que se deu muito mais ênfase à discussão da existência do conflito de interesses ${ }^{195}$, pouco se abordando acerca da aplicação do benefício particular em operações de incorporação de ações.

Apenas a Diretora Norma Parente consignou que a situação analisada no caso em discussão poderia ser considerada tanto como benefício particular como conflito de interesses. Interessante notar, nesse giro, que a julgadora demonstra que, no tocante ao instituto do benefício particular, alterou novamente seu ponto de vista a respeito da conceituação do instituto, voltando a defender que o benefício particular não pode ser entendido apenas como aquela vantagem auferida pelo acionista na qualidade de acionista, devendo possuir uma concepção mais ampla ${ }^{196}$.

Outro caso que provocou grandes discussões no âmbito da CVM foi a reestruturação do Grupo Telemar, noticiada ao mercado via fato relevante publicado em 17 de abril de 2006 (CASO TELEMAR - Processo Administrativo CVM RJ n. 2006/6785).

194 Alegam, ainda a existência de conflito de interesses do acionista e dos administradores e abuso de pode de controle.

195 O voto vencedor do relator Diretor Wladimir Castelo Branco, acompanhado pelo Diretor Marcelo Trindade, reconheceu a inaplicação da regra do artigo $115, \S 1^{\circ}$, da Lei $\mathrm{n}^{\circ}$ 6.404/76 frente à sistemática específica trazida pelo artigo 264 do mesmo Diploma Legal. Na visão do relator, "nas hipóteses de incorporação de sociedades sob controle comum, a lei das sociedades anônimas reconhece a submissão do interesse da companhia ao interesse do grupo, afastando, por conseguinte, a aplicação da regra sobre conflito de interesses nas deliberações assembleares (cf. art. 264, caput, e $\$ 4^{\circ}$ da Lei $n^{\circ}$ 6.404/76). Não se indaga se o acionista controlador exerceu seu direito de voto em conflito de interesses com a companhia, sendo sempre permitida a sua participação na formação da vontade social. A contrapartida para os minoritários consiste na garantia de uma equânime relação de substituição de ações [...]"

${ }^{196}$ Nas palavras da Diretora Norma Parente, "embora tenha admitido que benefício particular concernia apenas àqueles benefícios diretamente ligados à condição de acionista, hoje entendo, como o então Diretor Marcelo Trindade, atual Presidente desta CVM, que benefício particular deve ter uma extensão mais ampla". 
De acordo com o referido fato relevante, tal reestruturação tinha por objetivo simplificar a estrutura acionária das empresas do Grupo Telemar e reunir seus acionistas, distribuídos em três sociedades com seis diferentes classes e espécies de ações, em uma única companhia, com o capital dividido exclusivamente em ações ordinárias.

Para tanto, a reorganização societária previa a incorporação de ações da Tele Norte Leste Participações S/A por sua controladora Telemar Participações S/A, a conversão de ações preferenciais da Telemar Norte Leste S/A (controlada pela Tele Norte Leste Participações S/A) em ações ordinárias da mesma sociedade (seguido de resgate das ações não convertidas), bem como a futura migração dos acionistas ordinários da Telemar Norte Leste S/A para a Telemar Participações S/A, cujas ações passariam a ser negociadas no Novo Mercado, segmento especial de negociação de ações da BM\&F Bovespa.

Ademais, o fato relevante consignava que as ações ordinárias de emissão da Tele Norte Leste Participações S/A de propriedade da Telemar Participações S/A, bem como as ações ordinárias de emissão da Telemar Norte Leste S/A de propriedade da Tele Norte Leste Participações S/A, ou seja, as ações pertencentes, direta ou indiretamente, ao acionista controlador, teriam valor superior ao das demais ações ordinárias e preferenciais de emissão daquelas companhias. Deste modo, às ações não ligadas ao controle seria atribuído, para fins de determinação da relação de troca, valor equivalente a $80 \%$ (oitenta por cento) do valor atribuído às ações do acionista controlador.

Paralelamente, no curso da reorganização societária do Grupo Telemar, a CVM, em 18 de agosto de 2006, publicou o Parecer de Orientação $n^{\circ} 34$, com o objetivo de regrar a aplicação do artigo $115, \S 1^{\circ}$, da Lei $n^{\circ} 6.404 / 76$ às operações de incorporação e incorporação de ações.

O Parecer de Orientação $n^{\circ} 34$ foi publicado em um momento de efervescência do mercado de capitais, no qual se tornava bastante comum a realização de operações societárias, tais como intentada pelo Grupo Telemar, buscando a migração de ações de companhias 
abertas para segmentos especiais de negociação de ações por meio de uma incorporação de ações.

De acordo com o Parecer, muito embora tais movimentos sejam salutares, porque tais segmentos especiais de listagem proporcionam uma melhor governança corporativa das companhias abertas neles listadas, os mecanismos utilizados para tanto devem ser observados, de modo a não contrariar a legislação.

A preocupação da CVM ao publicar referido Parecer foi regrar a aplicação do instituto do benefício particular em operações de incorporação de ações nas quais fosse atribuído um valor maior às ações de emissão da companhia aberta pertencentes à sociedade controladora, ainda que o único ativo de tal sociedade controladora fosse essa mesma companhia. Vale dizer, situações nas quais o valor maior atribuído às ações do controlador não poderia ser justificado por um critério objetivamente verificável.

Na visão da CVM, esta relação de troca mais favorecida para a sociedade controladora, independentemente das espécies e classes existentes, sem que ela tenha ativos outros que justifiquem essa diferenciação de tratamento, pode ser considerada como o benefício particular de que trata o $\S 1^{\circ}$ do art. 115 da Lei $6.404 / 76^{197}$

Da mesma forma, a CVM entende como benefício particular a relação de troca mais favorável concedida aos demais acionistas detentores de direito de voto (não ligados ao

197 Nos termos do Parecer CVM 34, o fundamento utilizado para justificar a relação mais vantajosa tem sido o reconhecimento, com base no art. 254-A da Lei 6.404/76, de que as ações detidas pelo acionista controlador têm valor maior que as ações não integrantes do bloco de controle, na medida em que a alienação de controle não obriga a realização de uma oferta pública de aquisição para os titulares de ações da espécie preferencial sem voto, e obriga uma oferta pública de aquisição para os acionistas titulares de ações com direito a voto com desconto de $20 \%$ em relação ao preço pago ao acionista controlador. Ainda de acordo com o Parecer, a CVM entende que tal justificativa é válida no âmbito de uma OPA por alienação de controle, porque a lei assim o determina, mas não é suficiente para afastar o impedimento de voto por benefício particular quando, ao invés de uma parte independente (como é o terceiro adquirente do controle), quem confirma o sobre-preço às ações de titularidade da sociedade controladora é o próprio acionista beneficiado, ao votar na assembleia de incorporação. A CVM entende, entretanto, que tais mecanismos somente seriam eficazes para afastar a discussão sobre o impedimento de voto da sociedade controladora nas operações descritas caso a incorporação, ou a incorporação de ações, somente fosse aprovada pelo voto afirmativo de acionistas não beneficiados que completassem isoladamente o quorum legal. 
controle), em comparação aos acionistas não titulares de tal direito, salvo se a diferença de relação de troca basear-se em critérios objetivamente verificáveis (como o fluxo futuro de caixa descontado, ou as diversas cotações em mercados organizados).

Segundo o Parecer de Orientação no 34, em tais situações, o acionista beneficiado particularmente estaria impedido de votar, nos termos do $\S 1^{\circ}$ do art. 115 da Lei 6.404/76. Ainda de acordo com o Parecer, o mesmo impedimento de voto deve incidir se a operação for realizada de modo a conferir o mesmo número de ações da sociedade controladora a todas as espécies e classes de ações de emissão da Companhia, mas o número de ações emitidas pela sociedade controladora antes da operação for proporcionalmente superior ao número de ações da Companhia de que ela seja titular antes do negócio, resultando, na prática, na mesma desproporção que determina a existência do benefício particular das hipóteses anteriores.

Tendo em vista a publicação do Parecer de Orientação $n^{\circ} 34$, Luiz Leonardo Cantidiano, advogado atuante na reorganização societária do Grupo Telemar, endereçou consulta à CVM, tecendo algumas críticas ao Parecer de Orientação $n^{\circ} 34^{198}$ e fazendo duas perguntas em relação à sua aplicação à reestruturação societária anunciada pelo Grupo Telemar: (i) "Se ficar demonstrado que a relação de troca estabelecida na citada operação está compatível com preços recentemente praticados em nosso país em transações de alienação de controle de empresas que atuam no mesmo setor em que atua a Telemar, a CVM considerará tal aspecto como sendo um critério objetivo para determinação da aludida relação?" (ii) "Na eventualidade de as cotações de Telemar convergirem para a relação de troca anunciada - o que demonstraria uma aceitação dos agentes de mercado à proposta formulada pelos acionistas controladores - entenderia a CVM, neste caso, estar caracterizado um critério objetivo pelo fato de o mercado ter aceitado dita relação de troca?"

\footnotetext{
${ }^{198}$ No âmbito da CVM, as críticas abordaram os seguintes aspectos: (i) inconveniência da publicação de parecer para tratar em tese sobre incorporação de ações ou de sociedades, haja vista que questões dessa natureza devam ser objeto de análise caso a caso; (ii) súbita mudança de posicionamento acerca do assunto (vide Caso Petrobrás BR - Processos RJ2000/6117 e Caso Bunge Processo RJ2001/11663); (iii) benefício particular não configura impedimento de voto; (iv) desconsideração do art. 264 da Lei 6.404/76; (v) interrupção do processo de migração de companhias com controle concentrado para o Novo Mercado; (vi) não reconhecimento da mais valia do controle e perda do direito de venda conjunta dos acionistas ordinários não controladores (Art. 254-A); (vii) discriminação com relação ao direito dos acionistas ordinários não controladores.
} 
Em face de tal consulta, o então Diretor Pedro Oliva Marcilio de Sousa, em 17 de outubro de 2006, proferiu voto abordando as estratégias regulatórias aplicáveis para uma adequada administração dos mercados de valores mobiliários ${ }^{199}$, bem como o histórico de atuação da CVM em situações que deixaram transparecer a existência de um tratamento não equitativo entre os participantes do mercado ${ }^{200}$, tudo com o objetivo de justificar a publicação e o conteúdo do Parecer de Orientação nº 34.

199 Segundo o voto do Diretor Pedro Marcílio, "as normas de direito societário, normalmente, utilizam-se de três estratégias de intervenção, no que se refere ao seu conteúdo: (i) estratégia de proibição, (ii) estratégia de saída, e (iii) estratégia de legitimação(10). Essas estratégias podem ser assim descritas: (i) Estratégia de Proibição. Consiste na proibição de operações concretas ou na estipulação de termos e condições obrigatórios ou proibidos para certos negócios e operações. A Lei 6.404/76 utiliza pouco essa estratégia, especialmente em seu texto original. Após as reformas sofridas, ela foi utilizada, por exemplo, na proibição de emissão de partes beneficiárias pelas companhias abertas. A CVM utilizou essa estratégia quando editou a Instrução $319 / 99$ e decidiu o Caso Manah e o Caso TCP TCO. A estratégia de proibição tem, como maior problema, o fato de que pode impedir a implementação de negócios e operações benéficas, ou, ainda, fazer com que o acionista controlador procure obter a vantagem proibida por meio de outras operações em que os efeitos sejam mascarados ou que, simplesmente, impeçam a atuação da CVM; (ii) Estratégia de Saída. Consiste no oferecimento de um direito de saída ao acionista não controlador face a uma decisão unilateral do acionista controlador. Essa é a estratégia que foi utilizada de modo preferencial na Lei 6.404/76, no seu texto original, e mesmo após as reformas legislativas. Por exemplo, direito de venda conjunta em caso de alienação onerosa de controle (art. 254 e 255 originais e atual 254-A), necessidade de oferta pública em caso de cancelamento de registro de companhia aberta $\left(\right.$ art. $4^{\circ}, \S 4^{\circ}$ ) e aumento de participação de acionista controlador (art. $\left.4^{\circ}, \S 5^{\circ}\right), e$, também, nas hipóteses de direito de retirada (art. 137). A CVM utilizou essa estratégia no Caso Petrobras BR. O defeito da estratégia de saída é que impõe ao acionista que sofre os efeitos da decisão o ônus da saída em troca de um valor que, nem sempre, é adequado. Ela é, no entanto, a melhor estratégia para algumas situações em que não se pode falar em prejuízo (mesmo utilizando essa palavra em sentido amplo) aos acionistas ou benefício do acionista controlador, mas, apenas, em mudança de situação (como no caso da alienação de controle e aumento de participação); (iii) Estratégia de Legitimação. Consiste em conferir, aos afetados (ou a conselheiros independentes do acionista controlador ou da diretoria), o direito de aprovarem ou rejeitarem a operação que pode ser benéfica ao acionista controlador (ou ao grupo de acionistas com direito de voto ou aos diretores). Na Lei 6.404/76, essa estratégia é normalmente combinada com a estratégia de saída. Por exemplo, a alteração prejudicial dos direitos das ações preferenciais está sujeita à aprovação dessa própria espécie de acionistas e é seguida de direito de retirada pelos acionistas que não tenham aprovado as alterações (art. 137, $\$ 2^{\circ}$ ). A própria disciplina do direito de retirada vai nesse sentido, pois as matérias que ensejam a retirada estão sujeitas à aprovação de uma maioria qualificada (art. 136). Com a Lei 10.303/01, essa estratégia ganhou mais corpo, sempre combinada com a estratégia de saída. Um bom exemplo dessa combinação de estratégias é o processo de revisão de preço pelos acionistas destinatários da oferta de cancelamento de registro e de aumento de participação (art. $4^{\circ}$-A). A grande vantagem dessa estratégia é que permite que os próprios acionistas que incorrem os custos da decisão (ou administradores incumbidos de zelar por seus interesses) decidam sobre a sua pertinência".

${ }^{200}$ De acordo com o voto proferido pelo Diretor Pedro Marcílio, dos quatro casos selecionados (Caso Instrução CVM 319, Caso Manah, Caso BR Distribuidora e Caso TCO TCP), em três deles a CVM fez uso da estratégia de proibição (conforme nota de rodapé 142) e em apenas um caso (BR Distribuidora) se utilizou a estratégia de saída. 
Segundo o Diretor Pedro Marcílio, “a estratégia regulatória adotada no Parecer de Orientação 34/06 é a de legitimação, em seu estado puro. Entendeu a CVM não ser a melhor opção impedir a realização de uma operação que pode ser benéfica para a Companhia e, também, para todos os seus acionistas, a depender de seus termos. ${ }^{201,}$

Assim sendo, utilizando-se da estratégia da legitimação, o Parecer de Orientação no 34, reconhecendo a existência de benefício particular a determinados acionistas, no caso, aos acionistas titulares de ações ordinárias, conferiu legitimidade apenas aos demais acionistas não detentores dessa espécie de ações para aprovar ou reprovar operações societárias dessa natureza ${ }^{202}$, estando, segundo sustenta o Diretor Pedro Marcílio, baseado na própria interpretação do $\S 1^{\circ}$ do artigo 115 da Lei $n^{\circ} 6.404 / 76^{203}$.

Feitos os esclarecimentos acima, o Diretor Pedro Marcílio respondeu as indagações do consulente da seguinte forma:

"Pergunta $n^{o} 1$ 'Se ficar demonstrado que a relação de troca estabelecida na citada operação está compatível com preços recentemente praticados em nosso país em transações de alienação de controle de empresas que atuam no mesmo setor em que atua a Telemar, a CVM considerará tal aspecto como sendo um critério objetivo para determinação da aludida relação?' A resposta a essa questão é negativa. Incorporações nos moldes da proposta pela Companhia não são comparáveis a aquisições de controle. A primeira diferença que elimina a possibilidade de comparação é o fato de, na incorporação, inexistir um adquirente de controle. Daí decorre a segunda diferença, quando um proponente à aquisição de controle faz uma

\footnotetext{
201 Ainda segundo o Diretor Pedro Marcílio: $O$ desenvolvimento recente do mercado acionário brasileiro, o melhor aparelhamento dos investidores institucionais, o desenvolvimento da mídia financeira e empresarial, o reforço dos departamentos de análise dos bancos de investimento e das corretoras e o aumento da efetividade da atuação da CVM permitem a migração da estratégia de proibição para a estratégia de legitimação, em casos como o enfrentado pelo Parecer de Orientação 34/06, com ganhos para o sistema.

${ }^{202}$ Nesse sentido, esclarece o Diretor Pedro Marcílio: “Quanto à implementação da estratégia de legitimação, creio que a CVM poderia ter adotado uma qualquer de três posturas distintas: (i) voto apenas para os acionistas preferenciais que não fossem titulares de ações ordinárias; (ii) voto apenas para os acionistas preferenciais que não fossem beneficiados pela deliberação; e (iii) voto para todo e qualquer acionista preferencial". Como se verá adiante, o Colegiado da CVM, nos autos do Processo $n^{\circ}$ 2006/6785, acabou optando pela alternativa (iii), ficando vencido o Diretor Pedro Marcílio, que defendia a opção (ii).

${ }^{203}$ Conforme o Diretor Pedro Marcílio: "Acho importante, no entanto, reafirmar que, quanto à retirada do direito de voto de ações votantes, quem retira tal direito é a própria lei (art. $115, \$ 1^{\circ}$ ) e não o Parecer de Orientação 34/06."
} 
aquisição, ele fixa o preço levando em consideração o incremento de valor que poderá gerar na empresa, com sua administração (que julga, normalmente, melhor), e, também, as sinergias (com corte de custos, acesso a novos mercados para os produtos da sociedade adquirida e da adquirente, etc.). Nada disso está presente na incorporação descrita."

"Pergunta $n^{\circ} 2$ 'Na eventualidade de as cotações de Telemar convergirem para a relação de troca anunciada - o que demonstraria uma aceitação dos agentes de mercado à proposta formulada pelos acionistas controladores entenderia a CVM, neste caso, estar caracterizado um critério objetivo pelo fato de o mercado ter aceitado dita relação de troca?' Como se sabe, após o anúncio de uma reestruturação societária, as cotações das ações passam a convergir para a relação de substituição, variando dentro dela com relação à expectativa do mercado quanto à conclusão da operação e quanto à melhoria do preço. $O$ preço não se liga à aceitação da relação de substituição desejável, mas apenas à plausibilidade da conclusão da operação".

Paralelamente à consulta apresentada pelo advogado Luiz Cantidiano, o Grupo Telemar apresentou à CVM, em 06 de setembro de 2006, consulta para saber se acionistas titulares de ações ordinárias e preferenciais poderiam participar da votação, na assembleia de acionistas relativa à reestruturação societária anunciada pela companhia em abril de 2006, tendo em vista que essa reestruturação se enquadraria na espécie de reestruturação societária tratada pelo Parecer de Orientação nº 34 (Processo CVM 2006/6785).

O Diretor Pedro Marcílio foi designado relator do caso, pelo fato de já ter sido o relator da consulta anterior, construindo seu voto no sentido de que o Parecer de Orientação ${ }^{\circ}$ 34 respeitou o conceito de benefício particular que vem sendo repetido pela doutrina e legislação brasileira, qual seja, "benefício usufruível na qualidade de acionista (usualmente maior participação no capital social ou no direito ao recebimento de dividendos)".

Expõe ainda que o Parecer de Orientação $n^{\circ} 34$ trata exatamente da hipótese prevista na reorganização societária do Grupo Telemar, "na qual o benefício particular adviria de atribuição, ao acionista controlador, de uma participação maior no capital da sociedade resultante (ou remanescente) da Reestruturação Societária do que o percentual entregue por esse acionista". 
Conforme ainda o relator, o "custo desses benefícios seria suportado pelos acionistas preferenciais que receberiam uma participação no capital social da sociedade resultante inferior à que ele teria entregue. Tudo isso sem que um critério objetivo conseguisse conferir valores diferentes à participação de cada um desses acionistas e, portanto, transformar o que seria 'benefício particular' em atribuição correta de valor"

Segundo o entendimento do Diretor Pedro Marcílio, "se o 'benefício' recebido em decorrência da titularidade do conjunto de suas ações ordinárias for inferior (ou igual) ao 'custo' incorrido em decorrência da titularidade do conjunto de suas ações preferenciais, o acionista não terá 'benefício particular', pois terá suportado, ele próprio o 'custo' de seu 'benefício'. Caso, no entanto, o 'benefício' recebido seja superior ao 'custo' (e, portanto, ele venha a possuir, após a Reestruturação Societária parcela maior do capital social da companhia resultante) tem-se que o acionista não poderá votar, pois está recebendo um 'benefício particular' em decorrência da deliberação assemblear’.

Por essa razão, conclui que "só poderão votar, na Assembleia, os titulares de ações preferenciais e ordinárias que, ao final da Reestruturação Societária venham a ser titulares de um percentual de ações igual ou inferior ao que já detenham quando da Assembleia, excluindo-se do processo de votação todos os acionistas que, sendo titulares de ações preferenciais e ordinárias, venham a aumentar sua participação no capital social, com a aprovação da Reestruturação Societária, pois isso lhes conferiria um benefício particular".

No entanto, os demais membros do Colegiado da CVM discordaram da posição do Diretor Pedro Marcílio. O Diretor Marcelo Trindade apresentou voto por escrito defendendo o conceito de que o benefício particular tratado pelo Parecer de Orientação n 34 estaria atrelado às espécies de ações detidas pelos acionistas e não propriamente à pessoa do acionista em si, pois a vantagem decorrente da relação de troca fixada, não aferível por critérios objetivamente 
verificáveis, seria atribuída àquela espécie de ações como um todo e não apenas a um acionista em específico. Estaria associado, assim, a um conceito de coletividade ${ }^{204}$.

Deste modo, a vinculação do conceito de benefício particular a uma coletividade, e não a uma pessoa determinável, resultaria, na visão do Diretor Marcelo Trindade, "que uma mesma pessoa possa estar impedida de votar como membro da coletividade (isto é, como titular de uma certa espécie ou classe de ações), mas não estar impedido de votar como titular de outra espécie ou classe de ações. ${ }^{205,}$

\begin{abstract}
204 Segundo o Diretor Marcelo Trindade, “O Parecer de Orientação 34 admite a existência de um impedimento de voto decorrente de um benefício particular que aproveite a um conjunto de acionistas, identificado pelas espécies ou classes de ações de que sejam titulares, e não a certas pessoas determinadas - como necessariamente são as pessoas a que se referem as duas primeiras hipóteses tratadas pelo $\$ 1^{o}$ do art. 115 da Lei das S.A., de aumento de capital em bens de propriedade de um acionista e de aprovação de contas de um acionista que seja administrador. Em outras palavras: o Parecer de Orientação 34 admite a existência de um beneficio particular geral”.
\end{abstract}

205

O posicionamento do Diretor Marcelo Trindade pode ser melhor compreendido a partir da análise do seguinte trecho de seu voto: Assim, quando o impedimento de voto decorrer de um benefício que seria obtido por força de uma situação subjetiva, isto é, ligada à pessoa do acionista, o impedimento será dessa pessoa, quaisquer que sejam as ações de sua titularidade, e com todas elas. Dessa natureza são as duas primeiras hipóteses mencionadas pelo $\S 1^{o}$ do art. 115 da Lei das S.A. De outro lado, quando o impedimento de voto decorrer de um benefício que objetivamente atinja a toda uma classe ou espécie de ações, isto é, a toda uma categoria de acionistas - como ocorre nas hipóteses do Parecer de Orientação 34 -, o impedimento não alcançará a pessoa do acionista, com as demais ações de que seja titular, de outra classe ou espécie não impedida de votar. Quando o impedimento de voto decorrer de benefício particular que se produz na esfera jurídica da pessoa do acionista - necessariamente decorrente de uma situação extrínseca a sua qualidade de acionista, por conta da proibição de tratamento personalíssimo —, tal benefício determinará a vedação pessoal ao voto daquele acionista. Nesse caso, portanto, o acionista não poderá votar com quaisquer ações que detenha. Este é o caso das duas primeiras hipóteses de impedimento de que trata o $\$ 1^{\circ}$ do art. 115 da Lei das S.A., nos quais é correto vincular o impedimento à pessoa do proprietário do bem avaliado, ou à pessoa do administrador, por que essa vinculação decorre de fatores estranhos à condição de acionista (quais sejam, a propriedade de um bem admitido em aumento de capital, cujo laudo de avaliação será submetido à assembléia, ou a condição de administrador, cujas contas serão examinadas).Quando, entretanto, o impedimento de voto alcançar uma categoria de acionistas, porque decorra de um benefício que se produz igualmente por toda essa categoria (como nos casos do Parecer de Orientação 34), ele não se estende à pessoa do acionista, que, portanto, poderá votar com as ações das espécies ou classes não impedidas de que for titular. Entenda-se: o Parecer de Orientação 34 não reconheceu a incidência do impedimento de voto apenas de alguns acionistas titulares da classe ou espécie de ações beneficiada, dependendo de sua situação específica. Reconheceu o impedimento de voto de toda a espécie ou classe, por força de sua situação genericamente considerada, ou da situação particular da classe ou espécie, como se queira. Assim, nos casos tratados pelo Parecer de Orientação 34, de incorporação de sociedades ou de ações, em que o impedimento de voto decorre de uma situação relativa a um grupo de pessoas na qualidade de titulares de uma determinada espécie ou classe de ações, e não a um acionista por razões extrínsecas a essa qualidade, não terá lugar a extensão do impedimento de voto às pessoas dos titulares daquela classe ou espécie de ações, sob pena de agredir-se a impessoalidade que deve vigorar nas sociedades anônimas." 
Essa posição em relação ao Parecer de Orientação n. 34 acabou por se pacificar no âmbito da CVM, sendo utilizada para afastar posteriores reclamações de acionistas minoritários em relação ao assunto ${ }^{206}$.

No ano de 2007, todavia, a CVM novamente foi chamada a se manifestar a respeito da aplicação do instituto do benefício particular em operação de incorporação de ações, no CASO FERTIFÓS-FOSFÉRTIL (Processo Administrativo CVM n. RJ 2007/3453).

Tal processo originou-se de requerimento protocolado, em 10 de abril 2007, pela Mosaic Fertilizantes do Brasil S.A. e Mosaic Fertilizantes Ltda., acionistas detentoras, à época, de aproximadamente 33\% (trinta e três por cento) do capital da Fertifos Administração e Participação S.A, a qual, por sua vez, é a acionista controladora da Fertilizantes Fosfatados S.A. - Fosfertil (Companhia).

A Fertifos consistia em uma companhia de capital fechado controlada diretamente pela Bunge Investimentos e Participações Ltda e, indiretamente, por sua holding, a Bunge Brasil Holding BV.

O Requerimento previa solicitação de interrupção do curso do prazo de antecedência de convocação de assembleia geral extraordinária e especial de preferencialistas da Fosfertil, que iria deliberar acerca de sua reorganização societária, a qual envolveria a incorporação das ações da Bunge Fertilizantes S.A, cujo 99,98\% (noventa e nove por cento e noventa e oito décimos) de seu capital era detido pela holding Bunge Brasil Holdings BV, pela Fosfertil, com a conseqüente transformação da Bunge Fertilizantes S.A em subsidiária integral da Fosfertil.

Dentre as diversas irregularidades apontadas e que seriam passíveis de verificação pela CVM, encontrava-se a existência do benefício particular ao acionista controlador (Grupo

\footnotetext{
${ }^{206}$ Vide Processo Administrativo CVM n. RJ/2006/7166 (Reclamação apresentada por Argúcia Income Fundo de Investimento em Ações); Processo Administrativo CVM n. RJ/2006/8165 (Reclamação apresentada por HedgingGriffo Corretora de Valores S.A.).
} 
Bunge), que, com a incorporação de ações, aumentaria sua participação societária direta na Fosfertil, em detrimento do Grupo Mozaic, que teria sua participação societária diluída ${ }^{207}$.

A diluição do Grupo Mozaic acabaria por influenciar a própria governança da Fosfétil, uma vez que o Grupo Bunge passaria a deter a maioria direta em seu capital social, excluindo o Grupo Mozaic dos processos de decisão, os quais, anteriormente, se davam no âmbito da Fertifós ${ }^{208}$.

$207 \mathrm{Na}$ visão dos acionistas reclamantes: "Esse benefício decorrerá não apenas da incorporação das açães através de uma relação de troca desfavorável, mas também, para culminar, porquanto através da conversão de ações, a Bunge alcançará um percentual de participação na Fosfertil que lhe dará a maioria do capital votante, sem precisar de nenhum voto da Fertifos; Resulta claro, portanto, o benefício particular da Bunge na deliberação da assembléia especial de preferencialistas que irá deliberar sobre a conversão dessas ações, o que acarreta o impedimento da Bunge de votar nesse conclave; Essa interpretação está condizente com a manifestação da CVM no Parecer de Orientação $n^{\circ} 34 / 06$, segundo o qual o impedimento de voto se dá à vista da particularidade dos efeitos da deliberação relativamente a um acionista, comparado com os demais. Não estará a CVM emitindo, quanto a este aspecto, um julgamento sobre a ilicitude da deliberação - que poderia, em tese, ser um benefício lícito, mas apenas constatando, em tese preliminar, que há um benefício particular na decisão assemblear cogitada, na medida em que está vinculada à incorporação de ações e que, se todas as medidas propostas forem aprovadas, a situação da Bunge resultará absolutamente diversa da anteriormente vigente, com predomínio de sua vontade exclusiva; $O$ fato de o Parecer de Orientação n ${ }^{\circ} 34 / 2006$ se referir expressamente às operações de incorporações de ações de sociedades holdings não retira a validade da menção feita pelos Requerentes ao referido Parecer, visto que o controle circunstancial que a Bunge passou a exercer, lhe permitiu direcionar a operação de forma a satisfazer seus interesses; e o reconhecimento do impedimento de voto não levará essa D.CVM a emitir um julgamento sobre a ilicitude da deliberação - que poderia, em tese, ser um benefício lícito, mas apenas constatando, em sede preliminar, que há um benefício particular na decisão assemblear cogitada, na medida em que está vinculada à incorporação de ações e que, se todas as medidas propostas forem aprovadas, a situação da Bunge resultará absolutamente diversa da anteriormente vigente, com predomínio de sua vontade exclusiva".

208 Para maior aclaramento, cite-se trecho do relatório de manifestação da área técnica da CVM: "A informação de fundamental importância, no presente caso, é a de que segundo o art. 21 do estatuto social da Fertifos, compete ao Conselho de Administração, com voto afirmativo de sete dos conselheiros efetivos, deliberar sobre "o exercício do direito de voto pela Sociedade, em qualquer matéria, na qualidade de acionista controlador da Fertilizantes Fosfatados S.A. - Fosfértil.Uma vez adotado o processo de voto múltiplo, na eleição dos conselheiros, a Bunge Fertilizantes elegeria 5 membros, a Mosaic poderia eleger 3 membros e a Fertibrás a 1 membro desse conselho. Desse modo, as decisões que implicassem na orientação de voto da Fertifos na Fosfertil deveriam contar, em tese, com a concordância de conselheiros eleitos por Bunge e por Mosaic. Ocorre que, na ultima eleição para o CA de Fertifos (AGE de 27.04.07), a Mosaic não requereu o procedimento de voto múltiplo e todos os conselheiros de administração teriam sido eleitos por BUNGE. Após a referida reestruturação, que envolve a incorporação da Bunge Fertilizantes S/A pela Fosfertil e a posterior conversão das ações preferenciais da Fosfertil em ordinárias, a estrutura societária da Companhia ficará, como se segue: a Bunge Brasil Holding BV, juntamente com a Bunge Investimentos e Participações S.A. passam a deter 50,3\% das ações de emissão da Fosfertil, independendo de composição no conselho de administração de Fertifos (sem a conversão a participação das 2 empresas na Fosfertil seria de 49,6\%)." 
A área técnica da CVM, no que foi acompanhada pelo Colegiado, com a relatoria do Diretor Pedro Marcílio, indeferiu o pedido de interrupção da assembleia geral extraordinária e especial de preferencialistas da Fosfertil, não enfrentando diretamente a questão do benefício particular, apenas fazendo poucas ponderações a respeito ${ }^{209}$.

Todavia, o Grupo Mozaic ingressou com pedido de reconsideração ao Colegiado que, desta vez, contou com a relatoria do Diretor Sérgio Wegelin. No que se refere à análise da aplicação do benefício particular, o Colegiado da CVM entendeu que o simples fato de o Grupo Bunge aumentar sua participação societária direta na Fosfértil por meio da operação de incorporação de ações, de per si, não é suficiente para a caracterização do benefício particular, uma vez que tal ocorrência seria consequência matemática natural da expressiva participação societária que o Grupo Bunge já detinha na sociedade cujas ações foram incorporadas ${ }^{210}$.

\footnotetext{
${ }^{209}$ Confira-se a manifestação da área técnica da CVM: "Entendemos que, se há beneficio particular, no caso concreto, seria do acionista BUNGE, que, com a realização da operação, passaria a deter o controle direto da Fosfertil, não mais o exercendo via Fertifos. Nesse caso, a Bunge Investimentos e Participações S.A. e Fertifos Adm. e Part. S.A., controladas da Bunge Brasil Holding BV, estariam impedidas de votar com ações ON e PN. Cabe destacar que apenas 7,5\% das ações ON estão em circulação, o que levaria que a decisão de aprovar a Operação fosse tomada por essa minoria. Caso se entenda que o benefício particular do acionista existe e, que esses acionistas estariam impedidos de votar nas assembléias, entendemos que tal posicionamento não justificaria a interrupção ora solicitada, podendo resultar em uma manifestação prévia da CVM ou ser apreciado a posteriori.",
}

210 Extra-se o seguinte trecho de seu voto: "Com relação ao alegado impedimento de voto dos acionistas ligados ao Grupo Bunge, por força de um possível benefício particular advindo da acolhida da operação posta em deliberação, creio que não existe tal impedimento. O benefício particular no caso seria o fato de que o Grupo Bunge passaria a ser titular de ações suficientes para exercer o controle da Fosfertil independentemente da Fertifos e, portanto, sem ter que compartilhá-lo com as Reclamantes. A atribuição de ações à Bunge é conseqüência natural e necessária da incorporação de ações da BFE pela Fosfertil. Os critérios utilizados para determinar a relação de troca foram os mesmos para todos os acionistas, de modo que a circunstância de um acionista resultar, ao final, com uma posição destacada em relação aos demais é apenas a decorrência matemática da participação expressiva que este acionista já detinha na incorporada. Pode-se até questionar o fato de que a operação tenha sido toda arquitetada para dar maior estabilidade ao controle que a Bunge aparentemente já exerce sobre a Fosfertil. Isto, se for o caso, poderá configurar outros ilícitos, como já dito, mas não autoriza concluir que a operação em si, que é o que se analisa aqui, tenha propiciado à Bunge um benefício particular." 
Ainda no ano de 2007, especificamente no mês de julho, iniciou-se outra discussão no âmbito da CVM, envolvendo novamente a aplicação do instituto do benefício particular em operação de incorporação de ações. Tratou-se do CASO MG POLIÉSTER (Processo Administrativo CVM RJ 2007/8844).

No caso em questão, a então acionista controladora da MG Poliester S/A, a Mossi \& Ghisolfi International Spa, decidiu, no ano de 2006, constituir uma subsidiária integral, a MG Polímeros S.A., que atuaria no mesmo segmento de atuação da MG Poliéster S/A, uma companhia de capital aberto.

Pouco tempo após a constituição da MG Polímeros S/A, a Mossi \& Ghisolfi International Spa decidiu convocar uma assembleia extraordinária da MG Poliéster para aprovar a incorporação de ações da MG Polímeros, bem como uma assembleia especial de acionistas preferencialistas para aprovar a conversão de ações preferenciais em ordinárias.

Da mesma forma que no Caso Bunge exposto acima, os acionistas minoritários da MG Poliéster ingressaram com reclamação perante a CVM, requerendo a interrupção da referida assembleia geral extraordinária e especial, de modo a se apurar, dentre outros pontos, o impedimento de voto do acionista controlador no âmbito dessa assembleia geral extraordinária em decorrência do benefício particular que obteria em função do aumento de sua participação societária da MG Poliéster, em detrimento dos demais acionistas.

O Colegiado da CVM, acompanhando posicionamento de sua área técnica, indeferiu o pedido de interrupção dos aludidos conclaves, expondo que "a verificação das hipóteses de benefício particular do acionista controlador também só poderia ocorrer posteriormente à assembleia".

Tendo em vista tal posicionamento, os acionistas minoritários interpuseram pedido de reconsideração ao Colegiado da CVM, expondo, dentre outras alegações, que a CVM teria confundido os institutos do conflito de interesses, do benefício particular e do voto abusivo, ao afirmar que "qualquer conclusão quanto a eventual conflito de interesses ou benefício 
particular do acionista controlador, assim como quanto ao exercício abusivo do poder de controle, somente poderá se dar a posteriori da deliberação".

Em resposta, o Colegiado da CVM acatou a posição dos acionistas minoritários, reconhecendo a distinção dos institutos e que o impedimento de voto do acionista por benefício particular se dá previamente à deliberação, assim como nas duas primeiras hipóteses do $\S 1^{\circ}$ do artigo 115 da Lei $\mathrm{n}^{\circ} 6.404 / 76$, e informando, ainda, que a análise específica relativa à existência do benefício particular se fará apartadamente pela área técnica, retificando, assim, o posicionamento do Colegiado quanto a esse ponto no acórdão recorrido.

Voltando os autos para a área técnica, a Superintendência de Relação com Empresas consignou a inexistência do benefício particular no Caso MG Poliéster, por entender que as operações de incorporação de ações são reguladas por normas específicas (art. 264 da Lei $\mathrm{n}^{\circ}$ 6.404/76), as quais admitem o voto do acionista controlador.

No ano de 2009, com o CASO DURATEX-SATIPEL (Processo Administrativo CVM n.2009/5811), a discussão a respeito da aplicação do benefício particular nas operações de incorporação revisitou a CVM.

Dessa vez, o cerne da discussão foi a aplicação do Parecer de Orientação CVM n. 34 às operações de incorporação realizadas entre companhias independentes, no caso a Duratex S/A, que seria incorporada pela Satipel Industrial S/A. atribuindo-se aos controladores da Duratex S/A uma relação de troca mais vantajosa em comparação com os acionistas não-controladores. De fato, os acionistas controladores da Duratex S/A receberiam 3,05360401 ações da Satipel Industrial S/A, enquanto os acionistas não controladores receberiam apenas 2,54467001 ações.

A encaminhou ofício à Duratex S/A solicitando informações a respeito da mencionada operação, no que a Duratex S/A afirmou que a relação de substituição das ações foi baseada em negociações realizadas entre partes independentes, com fulcro nas cotações das ações envolvidas, a partir da divulgação da operação, situação que, em seu entender, seria 
distinta daquela comentada no Parecer de Orientação CVM n. 34, envolvendo tratamento diferenciado entre ações de uma sociedade holding e dos acionistas minoritários da companhia controlada pela sociedade holding, mesmo a sociedade holding possuindo como único ativo a referida companhia.

O tema foi encaminhado ao Colegiado da CVM, o qual, por maioria de votos, nos termos do voto apresentado pelo Diretor Marcos Pinto, entendeu que os controladores da Duratex S/A não poderão votar na deliberação da assembléia geral relativa à incorporação pela Satipel Industrial S/A, uma vez que em operações em que se estabeleçam relações de troca distintas para ações de diferentes espécies ou classes ${ }^{211}$, independentemente se realizadas entre partes independentes ou não ${ }^{212}$, todos os acionistas beneficiados estarão impedidos de votar,

211 Cite-se trecho do voto proferido pelo Diretor Marcos Pinto Barbosa: "O art. 115, $\$ 1^{\circ}$, da Lei $n^{o}$ 6.404, de 1976, deixa claro que "o acionista não poderá votar nas deliberações que puderem beneficiá-lo de modo particular". É preciso determinar, portanto, se a incorporação da Duratex pela Satipel confere um benefício particular aos acionistas controladores. Em caso afirmativo, os controladores da Duratex estarão impedidos de votar. Como se viu acima, a relação de troca prevista para a incorporação é mais vantajosa para os acionistas controladores, pois confere a eles um prêmio em relação aos demais acionistas. É óbvio, portanto, que a incorporação beneficia o controlador de modo distinto dos demais acionistas, o que é suficiente para caracterizar o beneficio particular, de acordo com o art. $115, \$ 1^{\circ}$. Infelizmente, a clareza desse dispositivo legal vem sendo obscurecida por controvérsias jurídicas. É que muitos sustentam, com base no direito estrangeiro e investigações históricas, que a expressão benefício particular tem um significado bem mais restrito do que o texto legal deixa transparecer. Nessa concepção, benefícios particulares são apenas as vantagens atribuídas aos acionistas enquanto sócios da sociedade. Não constituem benefícios particulares, desse ponto de vista, vantagens que não decorram da relação societária propriamente dita, como as advindas de eventuais contratos celebrados entre o acionista e a companhia. Pessoalmente, não vejo como sustentar essa restrição diante do texto legal.De qualquer forma, o presente caso escapa dessa polêmica, pois a relação de troca mais favorável é, sem sombra de dúvida, uma vantagem atribuída aos controladores da Duratex enquanto acionistas da companhia. Portanto, há benefício particular até mesmo na interpretação mais restritiva do art. $115, \S 1^{\circ}$.Nem se diga, invertendo o raciocínio, que a lógica acima deveria levar ao impedimento de voto dos demais acionistas da Duratex, pois eles também são afetados pela relação de troca. Esse sofisma pode ser facilmente respondido: embora cada acionista tenha interesse em definir uma relação de troca mais favorável para si próprio, apenas o controlador está recebendo tratamento especial.Portanto, não tenho dúvida alguma de que o art. $115, \$ 1^{o}$, da Lei $n^{o} 6.404$, de 1976, é aplicável a este caso. Concordo, por conseguinte, com a análise da SEP: os controladores estão impedidos de votar na deliberação a ser tomada pela assembléia geral da Duratex acerca da incorporação pela Satipel."

212 A Duratex argumenta, em contrapartida, que o prêmio implícito na relação de troca foi objeto de uma negociação entre duas companhias independentes, com intervenção das respectivas administrações, o que asseguraria sua comutatividade. Esse argumento não me convence, por duas razões.Em primeiro lugar, eventual negociação independente não afasta a necessidade de aprovação da operação pela assembléia, nem elimina o benefício particular atribuído ao controlador. Se a operação for mesmo comutativa e o benefício particular for justificado, os demais acionistas certamente aprovarão a operação. Mas, em qualquer caso, o procedimento legal precisa ser realizado: a assembléia deve deliberar, sem o voto do acionista particularmente beneficiado.Em segundo lugar, a ausência de relação de controle entre a Duratex e a Satipel não significa que o prêmio implícito na relação de troca foi realmente negociado de maneira independente. Para a Satipel, 
em razão da configuração do benefício particular, sendo que caso todos os acionistas com direito a voto estejam impedidos de votar, a companhia poderá convocar assembleia especial dos acionistas detentores de ações preferenciais para deliberar sobre a operação.

Cumpre, por fim, destacar que, neste caso, o Diretor Eli Loria vai além, entendendo que, mais do que conter benefício particular, a operação apresentada, no que tange à diferenciação de relação de substituição entre acionistas detentores de ações ordinárias, configura uma ilegalidade, pela infração ao disposto no artigo $15, \S 1^{\circ}$, da Lei n. 6.404/76, que veda a existência de classes de ações ordinárias na companhia aberta, bem como pela infração ao disposto no art. $109, \S 1^{\circ}$, da mesma Lei, que determina direitos iguais aos titulares de ações de mesma classe ${ }^{213}$.

Situação bastante similiar se deu no CASO SADIA-BRFOODS, ocorrido também no ano de 2009 (Processo Administrativo CVM n. RJ 2009/4691).

importava apenas o valor total da contraprestação a ser oferecida aos acionistas da Duratex, não como esse valor virá a ser distribuído entre eles. O objeto da negociação independente foi o valor relativo das duas companhias ou a relação média de substituição, pois é isso o que determina a diluição percentual dos acionistas de Satipel. O prêmio conferido aos controladores de Duratex não foi submetido a uma verdadeira negociação: ele foi fixado com base no art. 254-A, o que é inadmissível. Diante desses fatos, não vejo como afastar a conclusão do relatório de análise da SEP, segundo o qual o controlador da Duratex está impedido de votar na assembléia geral relativa à incorporação da companhia pela Satipel. Essa é, sem dúvida, a conclusão correta à luz do art. 115, $\$ 1^{o}$, da Lei $n^{\circ}$ 6.404, de 1976 (Trecho do voto proferido pelo Diretor Marcos P. Barbosa).

213 A operação apresentada, entretanto, no que tange à diferenciação de relação de substituição entre acionistas detentores de ações ordinárias, no meu entender, mais do que configurar benefício particular ao acionista controlador da DURATEX, nos termos do art. 115, $\$ 1^{\circ}$ ) (1), da lei societária, configura uma ilegalidade.

Trata-se de infração ao disposto no art. $\left.15, \S 1^{\circ}\right)(2)$, que veda a existência de classes de ações ordinárias na companhia aberta, bem como de infração ao disposto no art. 109, $\$ 1^{\circ}$ ) (3), ambos da lei societária, que determina direitos iguais aos titulares de ações de mesma classe.A ação ordinária na companhia aberta é de classe única e, portanto, possui características únicas, não podendo existir classes diferentes de ações ordinárias tal como a lei societária permite às ações preferenciais.Desta forma, todas as ações ordinárias devem ser tratadas igualmente, não se admitindo que as ações dos acionistas não controladores tenham um tratamento diverso daquele dado às ações detidas pelos acionistas controladores, não sendo o tratamento não isonômico passível de legitimação nem mesmo em uma assembleia em que somente votem os ordinaristas minoritários. (Trecho do voto proferido pelo Diretor Eli Loria). Na mesma linha do Diretor Eli Loria, o Diretor Otavio Yazbek concluiu que, embora considere, nos termos do voto apresentado pelo Diretor Marcos Pinto, haver benefício particular na operação proposta, entende não ser possível a diferenciação entre as relações de troca proposta, sustentando que a operação em questão não poderia sequer ser realizada. 
A diferença entre o caso Duratex-Satipel é que no Caso Sadia-BRFoods, a operação estava organizada em duas etapas, ao fim das quais a integralidade do capital social da Sadia passaria a ser detido, direta ou indiretamente, pela BRFoods, nova denominação da Perdigão S.A.

$\mathrm{Na}$ primeira etapa, as ações pertencentes aos integrantes do bloco de controle da Sadia seriam conferidas ao capital social de uma sociedade veículo, a HFF, recebendo os acionistas controladores da Sadia, por cada ação ordinária, uma ação do capital social da HFF. Ato contínuo, as ações de HFF seriam incorporadas pela BRFoods, de acordo com uma relação de troca de 0,166247 ação da BRFoods para cada ação da HFF.

A segunda etapa envolvia a incorporação das ações pertencentes aos demais acionistas da Sadia diretamente pela BRFoods, segundo uma relação de troca de 0,132998 ação da BRFoods para cada ação (ordinária ou preferenciais) de emissão da Sadia, detidas pelos acionistas minoritários.

Assim, a operação contemplava relações de troca diferenciadas, beneficiando os acionistas controladores da Sadia. Deste modo, o Colegiado da CVM, mais uma vez, por maioria de votos, tomando como base o julgamento do Caso Duratex-Satipel, entendeu existir benefício particular em favor dos acionistas controladores da Sadia, o que os tornavam impedidos de votar na assembleia que deliberaria sobre a incorporação da Sadia ${ }^{214}$.

\footnotetext{
214 A operação que hoje apreciamos é bastante similar à operação objeto do Processo CVM RJ2009/5811, decidido por este Colegiado em 28 de julho de 2009, portanto há menos de duas semanas. Assim como na incorporação da Duratex S.A. pela Satipel S.A., o acordo de associação entre Perdigão S.A. e Sadia S.A. prevê uma relação de substituição mais favorável para os controladores da Sadia do que a relação aplicável aos demais acionistas da companhia. A diferença entre as duas operações é formal. A incorporação da Duratex pela Satipel foi feita em apenas uma etapa, mas com duas relações de substituição, uma aplicável aos controladores, outra aos demais acionistas. Neste caso, a operação se dá em duas etapas: primeiro, ações de uma holding dos controladores da Sadia foram incorporadas pela Perdigão; agora, ações dos demais acionistas da própria Sadia serão incorporadas, mas com uma relação de troca menos favorável.Na prática, essas duas incorporações configuram uma única operação, por meio da qual Perdigão e Sadia combinarão seus negócios e suas bases acionárias. Ambas as incorporações foram objeto de um único acordo de associação, negociado entre os administradores e controladores das duas companhias. É evidente, portanto, que eles devem ser apreciadas em conjunto, seja do ponto de vista econômico, seja do ponto de vista jurídico; de outro modo, o art. 166, VI, do Código Civil teria incidência.Analisando a operação como um todo, fica claro que ela confere um benefício particular aos antigos controladores de Sadia. Ao final da operação, cada ação dos acionistas controladores de Sadia será substituída por 0,166247 ação da Brasil Foods S.A., nova denominação da Perdigão. Porém, cada
} 
Por fim, um último caso identificado que discutiu a aplicação do benefício particular em operações de incorporação de ações foi o CASO VIVO-TELESP (Processo Administrativo CVM RJ 2011/4394) ${ }^{215}$.

Neste caso, acionistas minoritários da Telecomunicações de São Paulo S/A Telesp ("Telesp") e da Vivo Participações S.A. ("Vivo") ingressaram com pedidos de aumento e interrupção do prazo de antecedência de convocação das assembleias gerais extraordinárias da Telesp e da Vivo, sob o argumento de que, dentre outros pontos, pelo fato de a Vivo e a Telesp serem duas companhias abertas sob controle comum indireto da Telefónica S.A, os acionistas das Companhias que integrassem o grupo da Telefónica S.A. deveriam estar impedidos de exercer o direito de voto nas referidas assembleias, nos termos do disposto no $\S$ $1^{\circ}$ do art. 115 da Lei 6.404/76, uma vez que estariam incorrendo em flagrante conflito de interesses e benefício particular. Acrescentam ainda os acionistas minoritários que o artigo 264 da Lei n. 6.404/76 não desautoriza a aplicação do $§ 1^{\circ}$ do artigo 115 da mesma Lei às operações de incorporação de ações.

O Colegiado da CVM, nos termos do voto da Relatora Presidente Maria Helena de Santana, indeferiu os pedidos dos acionistas minoritários, justificando que já se pacificou na Autarquia o entendimento de que, por força do artigo 264 da Lei n. 6.404/76, o qual estabeleceu um procedimento diferenciado e específico para as operações de incorporação de

ação dos demais acionistas de Sadia S.A. será substituída por apenas 0,132998 ação da Brasil Foods. Esse benefício particular não torna a operação ilegal, mas impede os acionistas controladores da Sadia e seus sucessores legais de votar na assembléia que deliberar sobre a operação, conforme dispõe o art. 115, $\$ 1^{\circ}$, da Lei $n^{\circ}$ 6.404, de 15 de dezembro de 1976. Por esse motivo, concordo com a manifestação de entendimento proposta pela Superintendência de Relações com Empresas (Voto proferido pelo Diretor Marcos P. Barbosa).

215 O Caso Oi (Processo Administrativo CVM n. RJ 2011/9011) tratou da questão envolvendo a aplicação do conflito de interesses nas operações de incorporação de ações e, da mesma forma que o Caso Vivo-Telesp, não admitiu o impedimento de voto do acionista por entender pela aplicação específica no artigo 264 da Lei $\mathrm{n}$. 6.404/76. Tal caso será abordado posteriormente por conta de outra questão envolvendo benefício particular em específico. 
ações para companhias sob controle comum, não se admite a aplicação do $§ 1^{\circ}$ do artigo 115 da Lei n. $6.404 / 76^{216}$.

Ademais, a Relatora acrescentou que o Parecer de Orientação CVM n. 35, que estabelece recomendações de conduta nas operações de incorporação de ações, pressupõe o direito de voto do acionista controlador, o qual apenas se tornaria impedido na hipótese definida pelo Parecer de Orientação CVM n. 34, qual seja, relação de troca distinta para acionistas da mesma classe e espécie em operações de incorporação de ações, o que, no entender da Relatora, não ocorreria no Caso Vivo-Telesp ${ }^{217}$.

\footnotetext{
${ }^{216}$ Nos termos do voto da Relatora: Os pedidos de interrupção do prazo de antecedência de convocação das AGE foram motivados pelo fato de a Vivo e a Telesp serem duas companhias abertas sob controle comum indireto da Telefónica S.A. Assim, segundo a Tempo, os acionistas das Companhias que integram o grupo da Telefónica S.A. estariam impedidos de exercer o direito de voto nas AGE, nos termos do disposto no $\$ 1^{\circ}$ do art. 115 da Lei $n^{o}$ 6.404/76, uma vez que estariam incorrendo em flagrante conflito de interesses. Ainda de acordo com a Tempo, não há nada que justifique que o disposto no art. 264 da Lei $n^{\circ}$ 6.404/76, aplicável às operações de incorporação de ações de companhias abertas sob controle comum, seja interpretado no sentido de autorizar o exercício do direito de voto nas AGE pelos acionistas integrantes do grupo de controle, em derrogação à regra geral do conflito de interesses prevista no disposto no $\S 1^{o}$ do art. 115 da mesma Lei. No entanto, não vejo como os pedidos podem prosperar, pois a argumentação levada a cabo pela Tempo se choca ao entendimento pacificado nesta Autarquia. Com efeito, ao apreciar o Processo Administrativo Sancionador $n^{o}$ RJ-2004-5494, em reunião de 16.12.04, o Colegiado da CVM firmou orientação no sentido de que as disposições do $\S 1^{\circ}$ do art. 115 da Lei $n^{\circ}$ 6.404/76 relativas a conflito de interesses não são aplicáveis às assembleias gerais convocadas para deliberar acerca das operações compreendidas pelo art. 264 da mesma Lei, uma vez que esse dispositivo submeteu tais operações a regime jurídico específico, que admite o exercício do direito de voto pelo acionista controlador.
}

${ }^{217} \mathrm{Na}$ visão da Relatora, o Parecer de Orientação CVM n. 35 "parte do pressuposto que, nessas operações, o acionista controlador não está legalmente impedido de exercer o direito de voto nas assembleias gerais de acionistas das duas sociedades envolvidas. Aliás, o Parecer me parece bastante claro quando ressalta que "é pacífico na CVM o entendimento de que o art. 264 da Lei $n^{\circ} 6.404$, de 1976, criou um regime especial para as operações de fusão, incorporação e incorporação de ações envolvendo a sociedade controladora e suas controladas ou sociedades sob controle comum, deixando claro que o controlador pode, via de regra, exercer seu direito de voto nessas operações". Esclareço, por oportuno, que o fato de o Parecer empregar a expressão 'via de regra' não significa, a toda evidência, que o exercício do direito de voto pelo controlador é excepcional ou possa ser restringido a juízo da CVM. Significa ao reverso, como me parece de fácil compreensão, que tal situação traduz a regra geral que, somente em casos excepcionais devidamente justificados, pode ser afastada, como, por exemplo, nas hipóteses em que houver algum benefício particular em favor do acionista controlador, que foram abordadas no Parecer de Orientação CVM $n^{\circ} 34$, de 18 de agosto de 2004. Em suma, conforme o entendimento consolidado nesta Autarquia, considero que nenhum dispositivo legal ou regulamentar restaria violado caso os acionistas integrantes do grupo de controle venham a exercer o direito de voto nas AGE convocadas a fim de deliberar sobre operação de incorporação de ações de controlada por controladora. Nos termos do art. 264 da Lei $n^{\circ}$ 6.404/76, tais acionistas estão legalmente autorizados a exercer o direito de voto nas referidas AGE. Diante disso, entendo que os pedidos de interrupção do prazo de antecedência de convocação das AGE devem ser indeferidos, por falta de fundamentação legal." 
Relatados os casos que passaram pela CVM envolvendo a aplicação do benefício particular em operações de incorporação de ações, observa-se que a discussão gira em dois pontos:

1) Se, genericamente, a vantagem referente ao aumento de participação de um acionista decorrente do processo de incorporação de ações, mormente aquelas envolvendo sociedades sob controle comum, pode ser considerado como um benefício particular;

2) se a vantagem relativa à atribuição de uma relação de troca mais favorável a determinadas ações em detrimento de outras de mesma classe e espécie pode ser considerado como um benefício particular.

No primeiro caso, tem-se a situação clássica de incorporação de ações envolvendo sociedades do mesmo grupo, tal como no Caso MG Poliéster e Caso Telesp-Vivo, citados acima.

Em circunstâncias como essas, é bastante comum a reclamação de acionistas minoritários que alegam diluição de suas ações em decorrência do aumento da participação do acionista controlador, causada, em seu entender, por uma avaliação mais favorável das sociedades em que o acionista controlador tem maior participação.

Tomando como exemplo o Caso MG Poliéster, o acionista controlador era detentor de aproximadamente $90 \%$ (noventa por cento) das ações representativas do capital da M\&G Poliéster S/A, companhia de capital aberto, e ainda possuía uma subsidiária integral, a M\&G Polímeros. A assembleia geral de ambas as companhias aprovaram a incorporação de ações da M\&G Polímeros pela M\&G Poliéster. Segundo a reclamação apresentada pelos acionistas minoritários, como visto acima, a subsidiária integral do controlador teria sido superavaliada em relação à companhia aberta, o que teria traduzido em uma relação de troca de 1:24, ou seja, a cada uma ação da $M \& G$ Polímeros entregue à $M \& G$ Poliéster, o acionista controlador recebia 24 (vinte e quatro) ações de sua emissão. 
Nesses casos, a primeira pergunta que se faz é se, por existir um procedimento específico instituído pelo artigo 264 da Lei $n^{\circ}$ 6.404/76 para as incorporações de ações, haveria espaço para a aplicação do $\S 1^{\circ}$ do artigo 115 da mesma Lei?

Há forte corrente de pensamento, encabeçada por CARVALHOSA ${ }^{218}$, LAMY FILHO $^{219}$, ARAGÃO ${ }^{220}$, RIBEIRO ${ }^{221}$ e FRANÇA $^{222}$, dentre outros, que defende a

\begin{abstract}
218 Os princípios adaptados do direito norte-americano pela nossa lei de 1976, nesse particular, são os seguintes: não existe impedimento para os controladores deliberarem na assembleia da incorporada sobre o negócio da incorporação. O. pressuposto é que prevalece o interesse social nessa deliberação. Ademais, pela exigência de quorum qualificado para as deliberações sociais sobre os negócios de incorporação e de fusão, seria impossível decretar o impedimento do voto dos controladores. Se tal ocorresse, não poderia haver deliberação eficaz (Comentários à Lei de Sociedades Anônimas. São Paulo: Saraiva, 2003, vol. 4, t.2, p. 283/284).
\end{abstract}

Observa, no entanto, Santagata - numa longa e proficiente análise do problema - que a exclusão do voto do majoritário importaria em gravíssimas consequências, pois ficaria a cargo da minoria fixar a relação de troca de ações; e, mais ainda, se este majoritário tivesse o controle, a incorporação seria impossível por falta de quorum especial nas assembleias (op. cit., p. 271/12). O controlador, prossegue o Autor, não está impedido de votar a deliberação da incorporação, pois que tal deliberação da assembleia é discricionária e cabe à maioria representar o interesse da sociedade como num todo; [...] (A Lei das S/A, vol. 2. 2 ed.Rio de Janeiro: Renovar, p. 576.

220 Reconhece a lei, por outro lado, que, na hipótese de incorporação envolvendo sociedade controladora, controlada ou sob controle comum, há a submissão do interesse da companhia ao interesse majoritário, não cabendo condicionar a operação a·uma verificação da possibilidade de haver o acionista controlador exercido o direito de voto em conflito de interesses com a companhia (situação co-natural à própria operação), sendo sempre permitida a sua participação na.formação da vontade social. O preceito legal contido no art. 264 da Lei 6.404/1976 é, portanto, a solução de equilíbrio encontrada pelo legislador pátrio com vistas a afastar a pertinência da discussão sobre a existência ou não de conflito de interesses em operações de incorporação envolvendo sociedades controladora, controlada ou sob controle comum que, em certos casos, tal como na incorporação de subsidiária integral que não tem outros acionistas que não o controlador, ou mesmo nas hipóteses em que a participação societária do acionista minoritário não perfaz quorum de aprovação, não poderia consumar-se a ela fosse aplicada sem-temperamentos a restrição de voto constante do art. 115 da mesma lei. Isto levaria, em regra, à inadmissível distorção de transferir para a minoria a decisão acerca da oportunidade e conveniência da incorporação que, como se sabe, é prerrogativa legitima da maioria acionária (Incorporação de Controlada: A Disciplina do art. 264 da Lei n. 6.404/76. In.: Direito Empresarial: Aspectos Atuais do Direito Empresarial Brasileiro e Comparado - Coord. Ecio Perin Jr, Daniel Kalansky e Luis Peyser -, p. 350/351).

${ }^{221}$ No caso de incorporação de companhia controlada, a sociedade controladora é, concomitantemente, parte na operação e votante na assembleia geral da incorporada. Mesmo diante de tal situação, não há proibição de de direito de voto. Primeiro porque o direito pátrio admite o chamado negócio consigo mesmo (figura próxima do self dealing transaction do direito norte americano), desde que não haja vedação expressa. Ou seja, como regra geral é permitido, sendo proibido apenas quando há disposição legal estabelecendo vedação. No caso específico, além de não haver proibição expressa em lei, deflui-se do próprio texto legislativo a possibilidade do voto da controladora. Por lei, a deliberação de incorporação exige quórum qualificado, devendo ser aprovada por acionistas que representem metade, no mínimo, das ações com direito a voto (Lei 6.404/76, art. 136, caput, e inc. $I V)$. A própria Lei Societária, que exige quorum qualificado, traz previsão específica para a incorporação de 
impossibilidade de aplicação do $\S 1^{\circ}$ do artigo 115 da Lei $n^{\circ} 6.404 / 76$, ao argumento de que o artigo 264 não veda a participação de qualquer acionista no âmbito do procedimento de incorporação de ações. Tais doutrinadores defendem ainda que a não aplicação da regra prevista no artigo 115 decorre do procedimento especial previsto pelo artigo 264 que já serve como proteção aos acionistas não participantes do grupo de controle.

Tal procedimento consistiria na exigência de apresentação aos acionistas da avaliação dos patrimônios, tanto da incorporadora como da incorporada, com base no parâmetro de patrimônio líquido a preços de mercado, a fim de que eles possam analisar se a relação de troca estabelecida no Protocolo de Incorporação é ou não eqüitativa.

A Comissão de Valores Mobiliários, como acima se demonstrou, também vem pacificando o entendimento de que o comando previsto no $\S 1^{\circ}$ do artigo 115 da Lei $n^{\circ}$ 6.404/76 não deve ser aplicado nas operações do artigo 264 da mesma Lei ${ }^{223}$.

companhia controlada, no seu artigo 264. Portanto, admite o voto da controladora para a realização da operação. Se a incorporadora fosse impedida de votar não haveria a possibilidade de incorporação de companhia controlada, por falta de quorum legal para a aprovação da operação na assembleia geral da incorporadora. Porém, a disposição legal do art. 264, ao disciplinar a incorporação de companhia controlada, admite o voto da controladora.

${ }^{222}$ Mas, de qualquer forma, se nós temos, de um lado, o art. $115, \$ 1^{\circ}$, que cuida das hipóteses gerais, de outro lado, temos o art. 264 - que cuida especificamente de incorporação de controlada ou de ações de controlada e constitui 'lex specialis' sobre a matéria, que não pode ser postergada. Tais operações constituem, inegavelmente, atos de organização, como os qualifica a doutrina alemã, em que todos os acionistas, em princípio, devem votar, pois está em jogo o destino da companhia. Na incorporação de controlada, ou se ações de controlada, o controlador, evidentemente, pode votar, bastando ler o que diz o $\$ 3^{\circ}$ do art. 264: ' $\$ 3^{\circ}$. Se as relações de substituição das ações dos acionistas não controladores, previstas no protocolo de incorporação, forem menos vantajosas que as resultantes da comparação previstas neste artigo, os acionistas dissidentes da deliberação da assembleia geral da controlada que aprovar a operação poderão optar, no prazo previsto no art. 230, entre o valor do reembolso fixado nos termos do art. 45 e o valor apurado em conformidade com o disposto no caput, observado o disposto no art. 137, inciso II'. Se o controlador não votasse, não se atingiria o quorum previsto no art. 136, IV, para as operações de incorporação ('metade, no mínimo, das ações com direito a voto') e não se compreenderia, minimamente, a previsão do direito de recesso..." (O Conceito de Benefício Particular e o Parecer de Orientação 34 da CVM. In: Tema de Direito Societário, Falimentar e Teoria da Empresa. São Paulo: Malheiros, 2009, p. 580).

223 Tal foi o entendimento adotado no Caso AMBEV (Processo CVM RJ 2004/5494), Caso Fertifós-Fosfértil (Processo CVM RJ 2007/3453), Caso MG Poliéster (Processo CVM RJ 2007/8844) e Caso Telesp-Vivo (Processo CVM RJ 2011/4394). Vale salientar também o Parecer de Orientação CVM n. 35, de $1^{\circ}$ de setembro de 2008, o qual consignou que "É pacífico na CVM o entendimento de que o art. 264 da Lei $n^{\circ}$ 6.404, de 1976, criou um regime especial para as operações de fusão, incorporação e incorporação de ações envolvendo a sociedade controladora e suas controladas ou sociedades sob controle comum, deixando claro que o controlador pode, via de regra, exercer seu direito de voto nessas operações”. 
Interessante notar que a discussão sobre a cumulação dos procedimentos não ocorre apenas no Brasil. Na França, SCHMIDT defende a aplicação de regras tendentes a impedir a ocorrência de benefício particular em operações de fusões e incorporações ${ }^{224}$.

Entende o autor francês que constitui um benefício particular, no âmbito de uma operação de incorporação, o fato de o acionista controlador absorver todo o patrimônio de sua companhia investida enquanto que os demais acionistas terão que se contentar apenas com o recebimento de ações de emissão do acionista controlador. Assim, haveria, para aquele autor, uma quebra da igualdade entre os acionistas.

Nesse sentido, SCHMIDT critica precedentes jurisprudenciais da Corte de Apelação de Douai e do Tribunal de Comércio de Roubaix, os quais, ao não reconhecer a existência de benefício particular em operações de incorporações dessa natureza, sequer chegam a discutir se os procedimentos poderiam ou não ser cumulativos.

Tais precedentes não reconhecem o benefício particular por entender que, se por um lado o acionista controlador absorve todo o patrimônio da companhia investida, entrega, aos demais acionistas, ações representativas de seu capital equivalentes ao valor do patrimônio dos sócios que foi incorporado. Assim, por haver equilíbrio nas prestações, não haveria que se falar em qualquer vantagem ou liberalidade, pois o acionista controlador não está recebendo mais do que está dando.

E com razão os Tribunais Franceses pois, como se viu no capítulo inaugural deste trabalho, o elemento liberalidade, que efetivamente dá azo ao ganho, justificando a vantagem, é imprescindível para a configuração do benefício particular.

Independentemente das discussões relativas à cumulação ou não de procedimentos, mais importante é analisar casuisticamente cada operação para concluir se

\footnotetext{
${ }^{224}$ SCHIMIDT, D. Les Conflits D’Intérêts Dans La Société Anonyme. Paris: Joly, 2004, p. 106-107.
} 
eventual vantagem obtida por determinado acionista pode ou não ser entendida como benefício particular.

Nestes termos, não constitui benefício particular o eventual aumento de participação acionária do acionista controlador em operações de incorporação de ações.

Relembrando, o procedimento de incorporação de ações exige que o patrimônio da companhia cuja ações serão incorporadas seja avaliado por profissional competente, que, fixando seu valor, será tomado como parâmetro para relação de troca de ações entre os acionistas.

Assim, considerando o caso típico de incorporação de ações entre empresas do mesmo grupo, em que a companhia cujas ações serão incorporadas pertence ao acionista controlador da sociedade incorporadora, o aumento da participação deste último na companhia incorporadora é decorrente do fato de ter entregado a ela as suas próprias ações que possuía da sociedade incorporada.

Assim, tomando como premissa de que a avaliação está correta, não há que se falar em benefício particular, pois a vantagem decorrente do aumento de capital não se dá a título gratuito, não constituindo uma liberalidade, um ganho para o acionista controlador; pelo contrário, sua contrapartida é a transferência das ações de emissão da companhia incorporada que possuía.

E mesmo que se admita que o patrimônio da companhia do acionista controlador está superavaliado, de modo a justificar uma vantagem ao acionista controlador, que passa a receber mais do que dá, não se pode falar em benefício particular, pois o benefício, nessa hipótese, passa a não ser lícito e a licitude da vantagem, relembre-se, é um dos requisitos para a configuração do benefício particular. 
Nessa última circunstância, estaria configurado o voto abusivo, ou seja, aquele que atribui uma vantagem indevida ao acionista, em prejuízo dos demais, mas não o benefício $\operatorname{particular}^{225}$.

Situação que também merece atenção é aquela trazida pelo Parecer de Orientação CVM n. 34. Como se viu, o referido parecer trata da hipótese de atribuição de diferentes relações de troca para ações de mesma classe, sem que haja uma justificativa objetivamente verificável.

De fato, tomando como premissa que em operações de alienações de controle o artigo 254-A da Lei n. 6.404/76 estabelece que as ações não pertencentes ao acionista controlador deverão ser adquiridas por um valor, no mínimo, equivalente a $80 \%$ (oitenta por cento) do preço atribuído às ações de controle, passou-se a fixar, no âmbito de incorporações, a relação de troca para as ações de controle com um ágio de $20 \%$ (vinte por cento) em comparação à relação de troca das demais ações, mesmo se tais ações fossem da mesma classe das ações de controle.

Conforme já se relatou, o Parecer de Orientação CVM n. 34 e o próprio Colegiado da Comissão de Valores Mobiliários, em duas oportunidades, entenderam pela existência de benefício particular em situações como essas.

Entretanto, não se configuram como benefício particular as vantagens conferidas às ações de controle, nas circunstâncias acima aventadas, haja vista que a atribuição da referida vantagem é indevida, ilícita, não amparada por Lei, já que o mecanismo previsto no art. 254-A, fundamento da atribuição de tal vantagem, não pode ser aplicado às operações de incorporações.

\footnotetext{
${ }^{225}$ Vale ressaltar que também não há que se falar em conflito de interesses nessa hipótese pois, muito embora a vantagem seja ilícita, não fica configurado o embate de interesses entre acionista e companhia, pois, neste caso, a companhia não será prejudicada. O voto do acionista não terá o condão de lesionar a companhia, mas apenas os outros acionistas.
} 
Isso porque, em primeiro lugar, o objetivo do dispositivo em questão é assegurar aos acionistas minoritários o direito de deixar a companhia no caso de uma troca de controle, concedendo-lhes maior liquidez. Assim, utilizar tal norma para justificar um prêmio ao acionista controlador no âmbito da relação de substituição de ações decorrente de uma operação de incorporação de ações é desvirtuar totalmente a finalidade da norma ${ }^{226}$.

Ademais, o citado artigo é aplicável somente às hipóteses de alienações de controle de companhias abertas, isto é, quando o acionista controlador cede a outrem, de forma onerosa, direta ou indiretamente, as suas ações representativas do controle da sociedade $^{227}$. Nos casos analisados, não há alienação de ações, pois, mesmos nos casos em que a incorporação provocou alteração de controle, o antigo acionista controlador não cedeu, não transferiu suas ações, evento fundamental para a aplicação do artigo 254-A, nos termos de seu texto normativo.

Por fim, a aplicação do artigo 254-A da Lei n. 6.404/76 às incorporações de ações, para fins de realização de oferta pública aos acionistas minoritários, já foi afastada pela Comissão de Valores Mobiliários ${ }^{228}$, não fazendo sentido, pois, utilizar-se de seu fundamento

\footnotetext{
${ }^{226}$ Com efeito, como afirmou o Diretor Marcos Barbosa Pinto, tal raciocínio "converte um direito conferido pela lei ao acionista minoritário em um benefício para o controlador. O art. 254-A não diz que as ações do minoritário valem $20 \%$ menos do que as ações do controlador. Ele dá ao minoritário o direito de vender suas ações por esse preço.A interpretação proposta pela Duratex subverte toda a lógica do art. 254-A, convertendo o tag along dos minoritários em um drag along para o controlador. Em termos econômicos, o entendimento da companhia cria uma opção de compra para o acionista controlador, quando a lei prevê uma opção de venda para o acionista minoritário.Se levássemos o raciocínio proposto pela companhia ao limite, chegaríamos à conclusão absurda de que os titulares de ações sem direito a voto não deveriam receber nada na incorporação, pois o art. 254-A não lhes dá o direito de vender suas ações em caso de alienação de controle. Obviamente, essa interpretação não pode prosperar” (Processo CVM RJ 2009/5811).
}

227 "A alienação do controle expressa no art. 254-A , seja ela direta ou indireta, pressupõe a existência de um acionista ou grupo de acionistas que, efetivamente, detenham o controle da companhia emissora das ações de sua titularidade, possibilitando, assim, a transferência onerosa desse poder a outro acionista ou a terceiro, que se tornará, então, o novo acionista controlador "(Decisão do Colegiado da CVM nos autos do Processo n. RJ 2007/14099, Rel. Diretor Durval Soledade, 29/1/2008).

228 "Ninguém tem dúvidas, acredito eu, que a incorporação de uma companhia não equivale a uma alienação de controle. A Lei n. 6.404/76 não deixa margem para discussão a esse respeito, , pois trata essas operações por meio de dispositivos distintos e de maneira completamente diversa. Tampouco resta dúvida, acredito eu, de que a incorporação não gera a necessidade de oferta pública aos acionistas das companhias diretamente envolvidas, 
para justificar a atribuição de um valor maior às ações de controle em operações de incorporações.

Sendo, pois, o benefício indevido, ilícito, não pode ser entendido tecnicamente como benefício particular ${ }^{229}$.

\section{3 - Redução do Valor Nominal de Ações com Implicações no Recebimento do} Dividendo Mínimo Obrigatório e nas Condicões para Resgate de Acões

Um dos primeiros casos a abordar a questão do benefício particular no âmbito da CVM, no final do ano de 2001, foi o CASO EDN (Processo Administrativo CVM . RJ 2000/4912).

A Companhia EDN - Estireno do Nordeste S/A possuía o capital social dividido em duas espécies de ações, ordinárias e preferenciais, sendo que essas últimas eram divididas em duas classes, A e B. As ações preferenciais da Classe A detinham uma série de vantagens específicas definidas no estatuto social.

Ocorre que, em 27 de julho de 2000, foi realizada assembleia geral extraordinária e especial de preferencialistas da Classe A, que aprovou a redução do valor nominal das ações preferenciais da Classe A (de R \$ 0,03/ação para R \$ 0,01169/ação), sob o argumento de que tal redução beneficiaria os acionistas preferencialistas detentores dessa classe de ações, os quais poderiam exercer seu direito de preferência em posterior aumento de capital na companhia em

nem mesmo quando ocorre mudança do acionista controlador de uma das companhias" (Decisão do Colegiado da CVM nos autos do Processo n. RJ 2008/4156, Rel. Diretor Marcos Barbosa Pinto, 17/6/2008).

${ }^{229}$ FRANÇA compartilha desse entendimento, ao afirmar que "Não há, pois, como evitar a conclusão de que não se trata, nos casos mencionados, de benefício particular, mas sim de vantagens indevidas, caracterizadora de conflitos de interesses" (O Conceito de Benefício Particular e o Parecer de Orientação 34 da CVM. In: Tema de Direito Societário, Falimentar e Teoria da Empresa. São Paulo: Malheiros, 2009, p. 579). Entretanto, a vantagem indevida decorrente dessa circunstância, se convalidada na assembleia pelo voto do acionista beneficiado caracterizará abuso de voto e não conflito de interesses, como dito na nota acima. 
condições mais favoráveis, pois, como se sabe, a emissão de novas ações não pode ser feita por valor inferior ao nominal (art. 13 da Lei n. 6404/76).

No entanto, alguns acionistas preferencialistas da Classe A levaram o assunto à CVM, por duas razões: (i) existiam vantagens definidas no estatuto social aos acionistas preferencialistas da Classe A que eram vinculadas ao valor nominal das ações, como o pagamento de dividendo mínimo obrigatório, que correspondia a 8\% (oito por cento) sobre esse valor nominal, e o valor de eventual resgate a ser deliberado, o qual deveria ser equivalente ao valor nominal; (ii) os acionistas preferencialistas da Classe A que aprovaram a redução do valor nominal das ações preferenciais da Classe A faziam parte do grupo controlador.

Assim, com a redução do valor nominal, os acionistas preferencialistas da Classe A entendiam que teriam seus dividendos reduzidos, em benefício dos acionistas ordinaristas, que passariam a receber a diferença decorrente dessa redução. Entendiam também que a redução do valor nominal facilitaria um eventual resgate de suas ações, o que fazia parte dos planos do acionista controlador.

O Relator do caso, Diretor Marcelo Trindade, observou, primeiramente que, muito embora a redução do valor nominal da ações preferenciais da Classe A não tenha implicado na alteração das participações societárias, acabou por gerar uma diminuição da parcela do capital social, em termos monetários, representada por essas ações, pois, multiplicando-se o número de ações existente pelo novo valor nominal, essa parcela teria se reduzido aproximadamente em três vezes ${ }^{230}$.

\footnotetext{
${ }^{230}$ Nas palavras do Diretor Marcelo Trindade: Como se vê, aparentemente a alteração levada a efeito pela deliberação assemblear não teria introduzido qualquer modificação no capital social da companhia, e portanto sua fixidez, protegida pelo art. 12 da Lei 6.404/76, não teria sido atingida, estando assim preservada a garantia dos credores. Ocorre que a aparente ausência de alteração esconde uma alteração efetiva: a parcela do capital social representada pelas ações preferenciais foi diminuída, pois o produto da multiplicação do número das ações preferenciais pelo seu valor nominal, que atingia $R \$ 15.367 .274,58$, passou a resultar em $R \$$ 5.988.114,66.
} 
Entretanto, entendeu que tal fato não configuraria um benefício particular ao acionista controlador, pois não alteraria o direito de preferência dos acionistas preferencialistas da Classe A, o qual seria exercido com base na proporção de ações em relação ao capital social, e não em relação ao valor dessas ações em relação ao capital ${ }^{231}$.

No que se refere à redução do dividendo, o Diretor Marcelo Trindade também não entendeu caracterizado o benefício particular, pois o beneficiado dessa situação não seria o acionista controlador, mas a companhia, que teria seus dispêndios reduzidos ${ }^{232}$.

Todavia, em relação às alterações nas condições de resgate das ações preferenciais da Classe A, defendeu o Diretor Marcelo Trindade que a facilitação do resgate configuraria um benefício particular ao acionista controlador, o qual teria interesse próprio em realizá-lo, pois implicaria no aumento de sua participação societária e nos acervos sociais ${ }^{233}$.

\footnotetext{
${ }^{231}$ Trecho do voto do Diretor Marcelo Trindade: No que diz respeito ao conflito de interesses, que impedisse o voto do acionista controlador, é de relembrar-se que tal acionista detém $100 \%$ das ações preferenciais classe B, e mais de $50 \%$ das Ações Classe A, tendo votado na assembléia especial que aprovou a redução do valor nominal. Efetivamente poder-se-ia cogitar, a meu ver, da existência de benefício particular do acionista controlador, como previsto no $\S 1^{\circ}$ do art. 115 da Lei 6.404/76, com a deliberação de redução do valor nominal, à luz do fato de que o aumento de capital a ser realizado após a redução do valor nominal será subscrito com créditos do acionista controlador, e portanto poder-se-ia falar em impedimento do voto do acionista controlador na deliberação da assembléia geral que delibere a alteração do estatuto.Ocorre que a significativa alteração da relação entre as ações ordinárias e preferenciais na participação no capital social, não alterará o direito de preferência dos acionistas titulares de ações preferenciais, quando de aumento de capital, que será exercido na proporção do número de ações, e não na proporção de sua participação no capital a ser aumentado.
}

232 Trecho do voto do Diretor Marcelo Trindade: Quanto à redução do dividendo, e demais consequências da redução do valor nominal, não me parece que se possa falar em conflito de interesses ou interesse particular do acionista controlador, pois tais fatos não beneficiam o controlador de maneira particular, mas sim a companhia, que tem diminuídos seus encargos.Anote-se, ainda, que se a redução do valor nominal das ações preferenciais fez com que, como antes demonstrado, a participação dos acionistas titulares de ações ordinárias (basicamente o controlador) no capital social da companhia aumentasse significativamente, passando eles a deter, por simples intermédio da operação, maior parte daquele capital, a partilha do acervo social, em caso de liquidação, se dará considerando-se o número de ações, e portanto sem benefício particular para os acionistas titulares de ações ordinárias.

${ }^{233}$ Trecho do voto do Diretor Marcelo Trindade: Por fim, resta a questão do resgate das Ações Classe A, cuja possibilidade foi anunciada na assembléia especial. E este me parece, em verdade, o ponto nodal da controvérsia.Caso tal resgate venha a ser deliberado, o preço de resgate será, segundo o estatuto, o valor nominal das ações. Tal deliberação, a meu sentir, faria com que a redução do valor nominal redundasse em benefício particular ao acionista controlador, pois após o resgate as ações seriam retiradas definitivamente de circulação, levando ao aumento da participação do acionista no capital e no acervo sociais.Dessa maneira, a facilitação do resgate, pela diminuição do valor a pagar (idêntico ao nominal), implicaria em deliberação social 
O Diretor José Luiz Osório de Almeida Filho acompanhou o Diretor Marcelo Trindade, com exceção ao entendimento da inexistência do benefício particular ao acionista controlador na hipótese de redução do dividendo mínimo obrigatório aos acionistas preferencialistas da Classe A. Segundo o Diretor José Luiz Osório, a vantagem consistente no incremento do lucro atribuível ao acionista controlador, consequência da redução de tal dividendo mínimo obrigatório, configura um benefício particular ${ }^{234}$.

No caso em questão, tem-se que a aprovação da redução do valor nominal das ações preferenciais da Classe A se deu com o voto de preferencialistas pertencentes ao grupo controlador, o qual teria sido beneficiado pela redução do dividendo obrigatório devido a essa classe de ações.

A situação parece configurar benefício particular aos acionistas ordinaristas. Isso porque se trata de vantagem lícita, de cunho patrimonial, atribuída a sócio na qualidade de sócio, que rompe a igualdade entre eles e advinda de forma gratuita, sem contraprestação.

De fato, trata-se de uma vantagem lícita. A deliberação social para a redução do valor nominal das ações, que acabou por atribuir vantagens aos acionistas ordinaristas, não foi irregular, como reconhecido pela própria $\mathrm{CVM}^{235}$. Destarte, a vantagem decorrente de tal deliberação, qual seja, o aumento da parcela dos lucros passíveis de distribuição aos acionistas ordinaristas, deve ser entendida como lícita e devida.

que beneficiaria o acionista controlador de modo particular, cujo voto estaria assim impedido, segundo a leitura que faço do $\$ 1^{\circ}$ do art. 115 da Lei 6.404/76.

${ }^{234}$ Trecho do voto do Diretor José Luiz Osório: Acompanho a conclusão do voto do Diretor Marcelo Trindade, salvo pelo fato de que, segundo meu entendimento, também na deliberação de redução do valor nominal das ações, porque importa na redução do valor do dividendo das ações preferenciais Classe A, o acionista controlador está impedido de votar.Na verdade, considerando que o acionista controlador, no caso, detém a integralidade das ações ordinárias e das ações preferenciais classe B e mais de $50 \%$ das ações preferenciais classe A, ele seria beneficiado pela diminuição do valor dos dividendos devidos às ações preferenciais classe A, na medida em que remanesceria maior parcela de lucros a ser distribuído às demais classes de ações.

${ }^{235}$ Extrai-se do voto do Relator Marcelo Trindade: “A redução do valor nominal não poderia ser inquinada de ilegal, como quis a decisão recorrida, porque (a) o valor nominal das ações pode ser reduzido por deliberação da assembleia geral desde que tal redução se dê de acordo com o sentido do art. 12 da Lei 6.404/76, isto é sem fraude ao capital social, que não ocorreu no caso, dado que a parcela de valor do capital foi transferida das ações preferenciais às ações ordinárias; $e(b)$ a referida redução fica condicionada, quanto à sua eficácia, à aprovação dos acionistas prejudicados, em assembleia especial (art. 136 da Lei 6.404/76), o que ocorreu." 
Não há dúvidas também de que a vantagem decorrente da redução do valor nominal é de cunho patrimonial, pois implica em aumento de direito aos fundos sociais, na medida em que os acionistas ordinaristas passarão a receber uma parcela maior do lucro da sociedade.

Da mesma forma, está bastante claro que a vantagem em questão é relativa a qualidade de sócio, já que atrelada ao recebimento de dividendos, rompendo a igualdade entre eles, pois não são todos os acionistas que estão sendo beneficiados, mas apenas os ordinaristas e os preferencialistas da classe B.

Por fim, vale também constatar que os acionistas beneficiados não estarão obrigados, em contrapartida à vantagem obtida, a realizar qualquer prestação, não fazendo do ato, pois, um evento equitativo, ficando caracterizada a liberalidade, pois o acionista, neste caso, receberá mais e não dará nada em troca.

O mesmo se pode dizer da vantagem relativa à facilidade de se resgatar as ações preferenciais, embora o benefício particular ao acionista, nesse caso, ocorra de forma indireta.

Vale dizer, a vantagem direta relacionada à diminuição do valor necessário para se proceder ao resgate das ações é da companhia, que despenderá de menos recursos para tal finalidade. O acionista ordinarista, no caso, será beneficiado indiretamente, pois o resgate implicará no aumento de sua participação no capital social, elevando, consequentemente, seu acesso aos fundos sociais, o que faz tal vantagem ter natureza patrimonial.

Como no evento anterior, a vantagem obtida pelo acionista é lícita, pois decorrente de regular procedimento de redução do valor nominal das ações preferenciais, e decorrente de sua qualidade de sócio. Da mesma forma, também não requer qualquer prestação por parte do acionista, lembrando que os recursos necessários para se proceder ao resgate será da companhia (artigo 44 da Lei n. 6.404/76). 
Um terceiro evento mencionado pelo presente caso diz respeito à alteração no exercício do direito de preferência à aquisição de ações da companhia. O Colegiado da CVM entendeu que, por não impactar no exercício de preferência dos acionistas preferencialistas, não haveria benefício particular neste aspecto.

Uma questão, porém, que se coloca é se a alteração de eventuais regras fixadas no estatuto social de uma companhia que diga respeito ao exercício do direito de preferência poderia ser considerado como benefício particular.

SCHIMIDT explora essa questão a partir da análise de um julgado da Corte de Cassação Francesa de 6 de março de $1935^{236}$. Segundo o autor francês, a Corte Francesa não considerou como benefício particular a vantagem consistente na liberação de um determinado acionista em relação à restrição de venda de ações fixada no estatuto social.

Apesar de ser reconhecidamente uma vantagem ao acionista, que poderá imprimir uma maior liquidez às suas ações, não implica em um maior acesso aos fundos sociais e seus frutos, o que, tecnicamente, não faz de tal vantagem um benefício particular.

\section{4 - Redução do Deságio de Crédito de Acionista a ser Integralizado em Aumento de} Capital na Companhia

Trata-se de discussão travada no âmbito do CASO CEMAR (Processo Administrativo CVM n ${ }^{\circ}$ RJ 2004/5580). Um grupo de acionistas minoritários levou à CVM reclamação apontando diversas irregularidades no âmbito da alienação de controle da Companhia Energética no Maranhão (Cemar), dentre as quais o tratamento do crédito detido pelo acionista controlador contra a Cemar quando de sua capitalização.

Os reclamantes alegavam que a capitalização do crédito do acionista controlador por valor muito próximo ao original já seria, em si, uma irregularidade, pois enquanto este

\footnotetext{
${ }^{236}$ SCHIMIDT, D. Les Conflits D'Intérêts Dans La Société Anonyme. Paris: Joly, 2004, p. 99-100.
} 
crédito teria sofrido um deságio de apenas 7\% (sete por cento), outros credores envolvidos na renegociação das dívidas teriam suportado deságios de até $69 \%$ (sessenta e nove por cento). $\mathrm{Na}$ visão dos acionistas minoritários, o crédito deveria ter sido avaliado por peritos, pois, segundo eles, crédito não se confunde com dinheiro, devendo assim seguir o disposto no art. $8^{\circ}$ da Lei 6.404/76.

Além disto, segundo os acionistas minoritários, o preço de emissão das novas ações decorrentes da capitalização ( $\mathrm{R} \$ 0,01$ por lote de mil), seria inapropriado uma vez que embasado em relatórios de avaliação que não consideravam a perspectiva de rentabilidade da Cemar (art. 170, $\$ 1^{\circ}$, I da LSA), alegando, ainda, conflito de interesses do acionista controlador na medida em que os laudos acima referidos, usados para justificar o preço de emissão das ações, haviam sido por ele encomendados.

O Colegiado da CVM entendeu pela desnecessidade do crédito detido pelo acionista controlador ser submetido à avaliação, nos termos do artigo $8^{\circ}$ da Lei n. 6404/76, pelo fato de a Cemar estar obrigada a quitá-lo pelo seu valor nominal. Até mesmo por essa razão, o Colegiado da CVM afastou a hipótese de existência de impedimento de voto do acionista controlador, já que, por configurar como seu direito receber o crédito a valor de face, qualquer desconto concedido, antes de consistir uma vantagem ou benefício, representaria uma liberalidade conferida pelo acionista controlador à companhia ${ }^{237}$.

\footnotetext{
${ }^{237}$ Trecho do voto proferido pela Diretora Norma Parente: A meu ver, o crédito só precisa passar pelo processo de avaliação de bens descrito no art. $8^{\circ}$ da Lei 6.404/76 quando existem dúvidas sobre sua certeza, liquidez e exigibilidade, o que não é o caso do crédito detido em face da própria companhia, reconhecido nas demonstrações financeiras elaboradas por seus administradores e ratificado pelos auditores independentes.A subscrição através de crédito desta natureza equipara-se à subscrição em dinheiro, até porque o dinheiro já existia e estava "dentro" da companhia. Além disto, a eventual avaliação do crédito só poderia vir a refletir seu valor "de mercado". Mas, como já exposto, este não é um parâmetro relevante, pois a Cemar, como devedora que era, estava obrigada a pagar o valor "nominal" da dívida, não o valor "de mercado". Trecho do voto proferido pelo Diretor Sérgio Weguelin: Como disse no parágrafo anterior, o valor de uma dívida, para o devedor é o valor nominal dessa dívida. Eventual desconto é ato de liberalidade do credor em favor do devedor (remissão parcial de dívida). Isto posto, ao celebrar um contrato cujo objeto é o desconto, não há conflito de interesses entre administrador do devedor e credor, mesmo que ele fosse a mesma pessoa. Conflito poderia existir caso, além do desconto, fossem alteradas outras características do crédito em benefício do credor, dado que não mais estaríamos frente a um ato de liberalidade, mas de uma simples novação em que se pactuam novas condições para a divida existente anteriormente. Tendo em vista tratar-se de um ato de liberalidade, o fato de o crédito do controlador ser integralizado com um desconto inferior ao aplicado aos créditos dos demais credores é irrelevante, a não ser que não se tenha dado conhecimento aos demais credores dessa negociação. Não há, no
} 
Este caso parece realmente ser mais simples que os demais já analisados. O ponto é saber se o menor deságio sofrido pelo crédito detido pelo acionista contra sua sociedade, em relação aos créditos dos demais credores, poderia configurar um benefício particular.

Ora, em primeiro lugar, há que se definir se realmente se está diante de uma vantagem. O Colegiado da Comissão de Valores Mobiliários entendeu que não, como visto acima, por entender que, salvo por anuência das partes, uma obrigação contratada deve ser satisfeita pelo seu valor de face, ou seja, para o devedor, a dívida deve ser considerada pelo seu valor nominal. Assim, eventual desconto seria mera liberalidade do credor. Nestes termos, capitalizar uma dívida pelo seu valor de face não pode ser considerada uma vantagem do credor, mas um direito seu.

Observe que o credor, ao não realizar um deságio, não aplicar qualquer desconto à dívida, está tão somente mantendo suas condições originais. Se as condições originais estão mantidas, como falar em vantagem?

Diferente seria, realmente, se estivesse ocorrendo a novação da dívida, com efetiva alteração de suas condições. Neste caso, poderia se falar em vantagem, se as condições fossem alteradas em prol do crédito do acionista. No entanto, não se poderia falar em benefício particular, pois que a vantagem não seria auferida pelo acionista na qualidade de acionista, mas de credor.

Assim, se a novação se der um prol do acionista-credor, em detrimento da companhia, poderá se estar diante do conflito de interesses, pois as alterações das condições do crédito podem prejudicar a companhia, mas não do benefício particular.

caso, contestação sobre esse fato por qualquer credor da Cemar, mesmo após a divulgação de todos os termos da renegociação das dívidas da Cemar. 
Uma situação interessante envolvendo alterações nas condições de crédito de um acionista em relação à sociedade é a seguinte: sabendo que a situação econômico-financeira da companhia não é das melhores, configuraria benefício particular a antecipação da liquidação do crédito detido pelo acionista, até com um desconto em relação ao valor de face, em detrimento dos créditos dos demais credores (não acionistas)?

Não há dúvida de que tal evento pode ser visto como uma vantagem ao acionistacredor. Essa vantagem, a princípio, seria lícita, pois decorrente da livre negociação entre credor e devedor: o devedor aceitou pagar antecipadamente sua dívida em razão do desconto recebido.

Entretanto, não é benefício particular por duas razões: a vantagem não é obtida pelo acionista na qualidade de sócio; não há liberalidade envolvida, pois a vantagem concernente à antecipação do vencimento da dívida possui como contrapartida o desconto concedido.

Se não é benefício particular, pode-se falar em conflito de interesses? A princípio também não, pois o evento não se deu contrariamente aos interesses da companhia, que se aproveitou do desconto concedido. Vale dizer, conceitualmente, desde que se tome como premissa que os representantes da companhia avaliaram financeiramente a situação e entenderam que valeria a pena antecipar a liquidação pelo desconto concedido, não há que se falar em conflito de interesses.

Se não é benefício particular e não é conflito de interesses, poderia se dizer que a deliberação que aprovasse tal evento contaria com o voto abusivo do acionista? Relembrando a dicção legal, o voto abusivo é aquele proferido com o fim de causar dano á companhia e aos demais acionistas ou de obter vantagem que não faz jus, em detrimento da companhia e acionistas. 
Deste modo, não parece também que o instituto do abuso de direito de voto possa ser aplicado ao caso, pois não se está prejudicando a companhia ou os demais acionistas e a vantagem é lícita.

Portanto, em uma situação como essas, o acionista com a vantagem poderá votar normalmente na assembleia que tratar da novação de seu crédito nestes termos, cabendo a eventuais lesados se socorrer de outros institutos do direito para discutir a questão ${ }^{238}$.

\title{
3.5 - Cancelamento de Dívida de Acionista contra a Companhia
}

A presente discussão se deu no bojo do CASO SABIN (Processo Administrativo $n^{\circ}$ 2005/4505). Os acionistas controladores do Centro Hospitalar Albert Sabin S/A (Companhia) pretendiam proceder ao cancelamento de registro de companhia aberta do Centro Hospitalar Albert Sabin S/A. Todavia, a CVM indeferiu o cancelamento por entender que ainda restavam em circulação debêntures emitidas pela companhia ${ }^{239}$.

\begin{abstract}
238 A situação, a depender das circunstâncias, poderá se caracterizar como falta de dever de lealdade do acionista controlador, conforme art. 116, $\S$ único, da Lei n. 6.404/76. Tal dispositivo determina que o acionista controlador deve exercer sua função sempre observando o dever de lealdade para com a Companhia, com os demais acionistas, seus empregados e com a comunidade que com ela interage (credores, p. ex.). O poder de controle é concebido pela legislação, portanto, como um "poder-dever", conforme se pode aferir do texto da Exposição de Motivos da Lei n. ${ }^{\circ}$ 6.404/76 (Mensagem n. ${ }^{\circ}$ 204, de 1976, do Poder Executivo):“O art. 116 da (sic) 'status' próprio, no direito brasileiro à figura do 'acionista controlador'. Esta é a inovação em que a norma jurídica visa encontrar-se com a realidade econômica subjacente. Com efeito, é de todos sabido que as pessoas jurídicas têm o comportamento e a idoneidade de quem as controla, mas nem sempre o exercício desse poder é responsável, ou atingível pela lei, porque se oculta atrás do véu dos procuradores ou dos terceiros eleitos para administrar a sociedade. Ocorre que a empresa, sobretudo na escala que lhe impõe a economia moderna, tem poder e importância social de tal maneira relevantes na comunidade que os que a dirigem devem assumir a primeira cena na vida econômica, seja para fruir do justo reconhecimento pelos benefícios que geram, seja para responder pelos agravos a que dão causa. O tema cresce em importância quando se considera que o controlador, muitas vezes, é sociedade ou grupo estrangeiro, que fica, por força de sua origem, excluído até mesmo das sanções morais da comunidade. O princípio básico adotado pelo Projeto, e que constitui o padrão para apreciar o comportamento do acionista controlador, é o de que o exercício do poder de controle só é legítimo para fazer a companhia realizar seu objeto e cumprir sua função social, e enquanto respeita e atende lealmente aos direitos e interesses de todos aqueles vinculados à empresa - os que nela trabalham, os acionistas minoritários, os investidores do mercado e os membros da comunidade em que atua."
\end{abstract}

${ }^{239}$ Anteriormente à Instrução CVM 480/09, que instituiu duas categorias de companhias abertas, o art. 17 da Instrução CVM n. 361/02, condicionava o cancelamento de registro de companhias abertas ao prévio resgate de eventuais debêntures emitidas. 
A companhia se defendeu alegando que realizou assembleia geral de debenturistas e deliberou pelo cancelamento de tais debêntures com a aprovação de 97,25\% (noventa e sete inteiros e vinte e cinco décimos por cento) dos debenturistas. Com relação aos demais, representativos de $2,75 \%$ (dois inteiros e setenta e cinco décimos por dento) das debêntures em circulação, a companhia informou que lançou crédito equivalente em conta corrente de cada um deles.

Entretanto, conforme informações levantadas pela área técnica da CVM, os debenturistas que aprovaram o cancelamento das debêntures eram os próprios acionistas controladores da companhia.

Além das discussões relativas à regularidade do procedimento de cancelamento de tais debêntures, o Diretor Sérgio Weguelin apontou a existência de benefício particular do acionista controlador no cancelamento de tais debêntures, entendendo que estaria impedido de exercer seu direito de voto na assembleia de debenturistas, por força do artigo $115, \S 1^{\circ}$, da Lei n. 6.404/76, aplicado às assembleias de debenturistas por força do artigo $71, \S 2^{\circ}$, da mesma $\operatorname{Lei}^{240}$.

Não há dúvidas de que o cancelamento da dívida de um acionista perante à companhia pode ser caracterizada como uma vantagem a tal acionista. Entretanto, não se pode falar em benefício particular.

\footnotetext{
${ }^{240}$ Segundo o entendimento do Diretor Sérgio Weguelin: "Por força do art. 71, $\S 2^{\circ}$, aplicam-se às assembléias de debenturistas, quando possível, as disposições relativas às assembléias de acionistas. Entendo que este é o caso do art. $115, \S 1^{\circ}$, que versa sobre o impedimento de voto em matérias que beneficiem o acionista de modo particular. Assim, o debenturista também estará impedido de votar nestas situações. No caso concreto, os debenturistas que votaram pelo cancelamento das debêntures eram acionistas (controladores) da Companhia. $\mathrm{Na}$ prática, estavam, perdoando uma dívida de que eram indiretamente os próprios devedores, o que indubitavelmente caracteriza um benefício particular. Por esse motivo, entendo que apenas os demais debenturistas deveriam ter votado sobre a matéria". Em nota de rodapé: "Com o impedimento de voto dos acionistas em situação de benefício particular, poder-se-ia suscitar um problema prático: a impossibilidade de se atingir o quorum de deliberação exigido no art. $71, \S 5^{\circ}$, ou seja ao menos a metade das debêntures em circulação. Parece-me que, neste caso, dever-se-ia interpretar o quorum em questão como ao menos a metade das debêntures cujos titulares não estejam impedidos de votar. Permitir o voto dos debenturistas impedidos apenas para alcançar o quorum previsto no dispositivo mencionado seria, a meu juízo, inverter o sentido da norma, facilitando a mudança das condições da debênture (o que tende a ser particularmente perigoso para o pequeno debenturista, cujo consenso não é indispensável), justamente quando a norma quis resguardar a estabilidade do que fora originalmente pactuado".
} 
Isso porque, em primeiro lugar, a vantagem não é auferida pelo acionista enquanto acionista, mas enquanto titular da condição de devedor junto à sociedade.

Se, todavia, tal cancelamento ocorrer em prejuízo da sociedade, poderá se estar diante do conflito de interesses.

\section{$\underline{3.6 \text { - Concessão de Bonificacão a Acionistas no âmbito de Reorganização Societária }}$}

Discussão recente envolvendo a conceituação de benefício particular se deu no CASO OI (Processo Administrativo CVM n. RJ 2011/9011). O presente caso envolve a reorganização societária do Grupo Oi, conforme fato relevante publicado na data de 24 de maio de 2011.

Antes da reorganização societária, o Grupo Oi possuía a seguinte estrutura: a Telemar Participações S/A controlava a Tele Norte Leste Participações S/A (companhia de capital aberto) que, por sua vez, controlava a Telemar Norte Leste S/A (companhia de capital aberto), controladora de uma sociedade veículo chamada Coari que, por sua vez, controlava a Brasil Telecom S/A (companhia de capital aberto).

A reorganização societária pretendida compreendia conjuntamente a incorporação de ações da Telemar Norte Leste S/A pela Coari e as incorporações da Coari e da Tele Norte Leste Participações S/A pela Brasil Telecom S/A, companhia esta que concentraria todas as participações acionárias atuais sociedades do grupo Oi e seria a única sociedade do grupo listada em bolsa de valores, passando a ser denominada Oi S.A.

No âmbito de tal reorganização societária, estava prevista a concessão de bonificação aos acionistas da Brasil Telecom S/A, permitindo a eles receber em dinheiro parcela das ações a que teriam direito na nova companhia (Oi S.A.). 
Na visão de acionistas minoritários de Telemar Norte Leste S/A e Tele Norte Leste Participações S/A, a bonificação concedida aos acionistas da Brasil Telecom S/A buscaria, ao fim, assegurar a manutenção do controle acionário da Telemar Participações S/A sobre a nova companhia. Isso porque, recebendo parte em dinheiro, teriam menos ações a receber na nova companhia, representando, pois, um benefício particular para Telemar Participações S/A, em razão do correspondente aumento em participação societária, a qual, na qualidade de controladora da Brasil Telecom S/A, estaria impedida de votar na deliberação, nos termos do $\S 1^{\circ}$ do artigo 115 da Lei $n^{\circ} 6.404$.

O Relator do caso, Diretor Otávio Yazbek, entendeu que não haveria que se falar em benefício particular por que todos seriam beneficiados igualmente pela bonificação; no mais, consignou também que a bonificação, de per si, não teria efeitos expressivos no aumento de participação da Telemar Participações S/A ${ }^{241}$.

Com razão o Colegiado da Comissão de Valores Mobiliários. Pela análise da operação como um todo, percebe-se que a bonificação foi concedida aos acionistas da Brasil Telecom S/A antes da reestruturação, ou seja, à sociedade Coari (que posteriormente foi incorporada pela própria Brasil Telecom S/A) e a seus acionistas minoritários.

\footnotetext{
${ }^{241}$ Nos termos do voto do Relator: [...] o benefício particular é, usualmente, definido como aquela vantagem que diferencia um acionista dos demais, beneficiando-o na qualidade de acionista. Ou seja, existe benefício particular quando se subtrai, à coletividade dos acionistas, algo que seria direcionado para um outro acionista, que, assim, se diferenciaria dos demais. Não se trata de benefícios decorrentes de uma contratação privilegiada (hipótese de conflito de interesses), mas algo que diferencia os acionistas como tais. E no caso em tela não há que se falar propriamente em uma diferenciação decorrente da deliberação acerca da bonificação, no âmbito da BrT. Nesta, todos seriam igualmente beneficiados pela bonificação e pelo resgate. É bem verdade que o problema poderia aparecer na etapa subseqüente da reestruturação societária, uma vez que, com as participações dos minoritários da BrT reduzidas em razão do pagamento da bonificação, será mais fácil para a TmarPar consolidar sua posição de controladora daquela sociedade. E aqui se impõe, inicialmente, identificar se é de benefício particular que se estaria tratando aqui. Entendo que não, inclusive porque, por mais que se imponha a compreensão das operações como um todo, não é possível estender a hipótese de vedação de voto de maneira irrestrita, de modo a abranger operações sobre as quais não se está decidindo em um primeiro momento. Além disso, creio que as Companhias lograram, além disso, demonstrar que, para tais efeitos, a bonificação produziria efeito bastante reduzido, ou seja, mesmo caso ela não seja realizada, restará consolidada a posição de controladora da TmarPart. Daí porque afasto os questionamentos trazidos também neste ponto.
} 
$\mathrm{Na}$ visão dos reclamantes, a bonificação ensejou uma vantagem ao acionista controlador final (Telemar Participações S/A), consistente no aumento de sua participação ao término da operação, na medida em que implicou na monetização da participação dos acionistas da Brasil Telecom S/A, via distribuição de dinheiro pelo resgate das ações objeto da bonificação, interferindo na relação de troca das ações.

Ocorre que, como se observa da estrutura acionária do Grupo Telemar, não eram apenas os acionistas pertencentes ao grupo controlador que figuravam como acionistas indiretos da Brasil Telecom S/A, mas também acionistas detentores de ações negociadas na Bolsa de valores. Como eles não receberam a bonificação, todos esses acionistas, teoricamente, foram beneficiados com o aumento de suas participações societárias ao final da reestruturação societária.

Vale dizer, o efeito da bonificação não foi direcionado apenas à Telemar Participações S/A, mas a todos os acionistas de Telemar Norte Leste S/A e Tele Norte Leste Participações S/A, inclusive aqueles não pertencentes ao grupo de controle.

Isso significa que a vantagem em questão não foi exclusiva de um acionista ou grupo de acionistas, gerando efeitos para todos os acionistas indiretos da Brasil Telecom S/A, razão pela qual não há que se falar em benefício particular. 


\section{CONCLUSÃO}

O instituto do benefício particular, trazido pelo artigo $115, \S^{\circ}$, da Lei n. 6.404/76, tal como o conhecemos hoje no Brasil, tem origem no direito estrangeiro, sobretudo francês, que estabeleceu suas bases de conceituação.

Com efeito, por meio da análise da doutrina e legislação francesa, é possível traçar alguns contornos do instituto do benefício particular, além de compreender sua razão de ser, ou seja, os motivos que levaram o legislador pretérito a criá-lo. De fato, almejava-se, à época, afastar ou mitigar os abusos e inconveniências de o sócio aprovar, em sede de assembleia geral, a atribuição de vantagem especial e exclusiva em seu próprio favor. Assim, foi criado mecanismo segundo o qual o sócio beneficiado particularmente não participava da deliberação que aprovaria a concessão de tal vantagem.

Deste modo, desde os seus primórdios, a vantagem associada ao instituto do benefício particular não tinha as características de uma ilicitude, de algo contrário à lei, que pudesse prejudicar terceiros, mas sim de vantagem lícita, perfeitamente possível de ser concedida a alguém. A única restrição seria a proibição de voto do acionista beneficiado particularmente, demonstrando, assim, que o instituto esteve desde sempre fundamentado em preceito de ordem ética, segundo o qual ninguém poderia ser juiz de seus próprios atos (Nemo Iudex In Causa Propria).

Ademais, verifica-se também que as vantagens a que o legislador se preocupou em regrar quando criou o instituto do benefício particular eram vantagens de cunho social, que o acionista somente poderia obter na qualidade de acionista, sobretudo no momento da constituição da sociedade, não se referindo às vantagens extrassociais.

Vale também destacar que, muito embora o Direito Alemão, atualmente, não trate do instituto do benefício particular tal como a legislação brasileira vigente, o caráter da 
licitude da vantagem do benefício particular pode ser corroborado a partir da análise comparada da legislação alemã do final do século XIX e início do século XX.

Mas foi realmente na França que o conceito de benefício particular assumiu seus contornos atuais, por meio da construção doutrinária e jurisprudencial.

A doutrina francesa, desde o final do século XIX, também associava o benefício particular à vantagem especial e exclusiva que rompia a igualdade mantida entre os acionistas. Todavia, a partir da Lei Francesa de 24 de julho de 1966, o conceito de benefício particular foi estendido à vantagem concedida a sócios ou não sócios, de modo que o critério do rompimento da isonomia deixou de ser reconhecido como um critério seguro para sua conceituação, passando a ganhar força entendimento consignado em um antigo acórdão da Corte de Cassação de Paris, de 6 de março de 1935, segundo o qual não bastaria que a vantagem rompesse com a igualdade entre os acionistas, seria preciso, antes de tudo, que a vantagem concedesse ao beneficiado uma preferência sobre os fundos sociais e seus produtos.

Destarte, mesmo que a natureza do benefício particular não seja necessariamente pecuniária, sempre deverá ter impacto, ao menos de forma indireta, nos direitos dos demais acionistas sobre o patrimônio da companhia e seus frutos. Entretanto, sem desprezar o conceito de rompimento da isonomia entre os acionistas (relembrando-se que, no Brasil, o benefício particular só é regulado em relação ao sócio), pode-se afirmar que o benefício particular conceitua-se como toda vantagem lícita que tenha condições de causar um desequilíbrio entre os acionistas, relativamente as suas respectivas posições acionárias, no acesso aos fundos sociais.

Partindo da premissa de que o conceito de benefício particular poderia ser ligado à vantagem extra que determinado acionista retira do patrimônio social, a doutrina francesa passou a associá-lo também à liberalidade, gratuidade, favor, podendo ser entendido ainda como a vantagem lícita que tenha condições de causar um desequilíbrio entre os acionistas, relativamente as suas respectivas posições acionárias, no acesso aos fundos sociais, que lhe foi concedida gratuitamente. 
Todos esses elementos caracterizadores do instituto do benefício particular contribuem para traçar uma fronteira mais segura em relação ao instituto do conflito de interesses, evitando-se, assim, indesejáveis equívocos de interpretação pelos operadores do direito.

A doutrina nacional e estrangeira, de forma majoritária, consolidou-se no sentido de atribuir à vantagem perseguida pelo acionista conflitado duas principais características: a ilicitude e o caráter extrassocial, de tal sorte que não há como co-existir o benefício particular com o conflito de interesses, pois, em um caso a vantagem será ilícita e noutro, lícita, sendo o limite entre um caso e outro a possibilidade de violação do interesse social.

Não há como admitir, assim, a ideia de que o conceito de benefício particular esteja contido no conceito de conflito de interesses, pois a vantagem que o acionista conflitado com o da companhia experimenta não é uma vantagem lícita, ao contrário da vantagem associada ao benefício particular. Assumir, portanto, que o conceito de um está atrelado ao outro é não considerar a expressão "benefício particular" na acepção técnica do termo, desprezando toda a história de construção conceitual do instituto.

Conclui-se, assim que, apesar da aparente semelhança entre o benefício particular e o conflito de interesses, tratam-se de institutos distintos, criados para regular situações diversas.

Registre-se, por fim, que a distinção entre ambos os institutos faz-se necessária, pois vêm sendo utilizados de forma bastante recorrente pelos aplicadores do direito, discutindo-se a respeito de sua aplicação tanto em operações societárias, tais como nas incorporações, como em transações envolvendo partes relacionadas.

Ocorre que, a partir da análise de posicionamentos da Comissão de Valores Mobiliários a respeito do assunto, percebe-se que muitas vezes o instituto do benefício particular não é corretamente aplicado. 
Talvez no afã de conferir-lhe uma aplicação prática mais contundente, muitas vezes têm-se alargado indevidamente os contornos do instituto, a ponto de confundi-lo com o conflito de interesses ou mesmo com o voto abusivo.

A Lei n. 6.404/76, ao regrar as relações entre os acionistas no âmbito de uma assembleia geral, estabeleceu uma estrutura própria com o fim de regular cada situação em específico com um instituto próprio, esperando que cada um cumprisse com seu papel, de modo a evitar interferências indesejáveis.

O que o aplicador do direito muitas vezes vem fazendo, tal como observado pelos posicionamentos da Comissão de Valores Mobiliários, é alargar de tal forma o conceito do benefício particular como se ele fosse o único mecanismo hábil a disciplinar a relação entre sócios no bojo de uma assembleia geral, a ponto de invadir campos de atuação de outros institutos, gerando confusões conceituais desnecessárias.

Tal fato acaba por criar uma indesejável insegurança jurídica que, sem sombras de dúvidas, prejudica a dinâmica dos negócios sociais e contraria as próprias bases históricas e teleológicas do instituto.

De acordo com o que se apurou, o instituto do benefício particular deve ser interpretado de forma restrita, de modo que possa alcançar somente aqueles eventos que efetivamente se enquadram dentro de seus contornos conceituais e que inspiraram o legislador francês do século XIX a instituí-lo.

Portanto, o instituto do benefício particular merece ser observado com uma maior acuidade pelos aplicadores do direito, de forma a possibilitar sua correta aplicação, em prol do fortalecimento das instituições societárias e da segurança jurídica de uma forma geral. 


\section{BIBLIOGRAFIA}

ARAGÃO, Paulo Cezar e LIMA, Monique Mavignier. Incorporação de Controlada: a disciplina do art. 264 da Lei 6.404/76. In: Perin Jr., Écio et alli (Coord.). Direito Empresarial: aspectos atuais do direito empresarial brasileiro e comparado. São Paulo: Método, 2005.

ANGÉL, Jaime Giraldo. Hermenéutica Juridica: Homenaje al maestro Darío Echandía. Santa Fé de Bogotá: Rosaritas, 1997.

ANDRADE, André Martins. Anotações a Lei das Sociedades Anônimas. São Paulo: Atlas, 1977.

ASCARELLI, Tulio. Studi in Tema di Società. Milão: Giuffrè, 1952,

ASQUINI, Alberto. I Batelli del Reno. Rivista delle Società, n.4, 1959.

BARBOSA $\mathrm{F}^{\circ}$, Marcelo Fortes. Sociedade Anônima Atual: Comentários e anotações às inovações trazidas pela Lei ${ }^{\circ} 10.301$ ao texto da Lei $n^{\circ}$ 6.404/76. São Paulo: Atlas, 2004.

BATALHA, Wilson de Souza Campos. A nova Lei das S/A. São Paulo: LTr, 1998.

BETARELLO, Fábio Campos. Governança Corporativa: Fundamentos Jurídicos $e$ Regulação. São Paulo: Quartier Latin, 2009.

BORBA, José Edwaldo Tavares. Direito Societário, 9a Ed. Rio de Janeiro: Renovar, 2004.

BULGARELLI, Waldirio. Regime Jurídico de Proteção às Minorias nas S/A. Rio de Janeiro: Renovar, 1998. 
BULHÕES PEDREIRA, José Luiz. e LAMY Fo , Alfredo (Coord.). Direito das Companhias, v.I e II. Rio de Janeiro: Forense, 2009.

A Lei das S.A. 2a ed, v. I e II. Rio de Janeiro: Renovar, 1992.

CARNELUTTI, Francesco. Teoria Geral do Direito. Rio de Janeiro: Âmbito Cultural, 2006.

CANOtILHO, José Joaquim Gomes. Direito Constitucional e Teoria da Constituição. Coimbra: Almedina. 1995.

CARVALHO DE MENDONÇA, José Xavier. Tratado de Direito Comercial Brasileiro, v. IV. São Paulo: Freitas Bastos, 1946.

. Tratado de Direito Comercial Brasileiro, Vol.

II, atualizado por Ricardo Negrão. Campinas: Bookseller, 2000.

CARVALHOSA, Modesto; EIZIRIK, Nelson. A Nova Lei das S/A . São Paulo: Saraiva, 2002.

CARVALHOSA, Modesto. Comentários à Lei das Sociedades Anônimas. São Paulo: Saraiva, 2009.

COMESAÑA, Julio Costa. El dever de Abstención Del Socio em las Votaciones. Valencia: Tirant lo Blanch, 1999.

COMISSÃO DE VALORES MOBILIÁRIOS. Acórdão proferido nos autos do Processo Administrativo $n^{o}$ RJ 2000/4912, de 19 de março de 2002. Disponível em http://www.cvm.gov.br/port/descol/resp.asp?File=2002-012D19032002.htm. Acesso em 19/07/2011.

Acórdão proferido nos autos do processo administrativo RJ 2006/6785, na data de 25 de setembro de 2006 (Caso Telemar). Disponível 
em http://www.cvm.gov.br/port/descol/respdecis.asp?file=5264-0.htm. Acesso em 29 de maio de 2009.

Acórdão proferido nos autos do Inquérito Administrativo CVM $n^{\circ}$ TA-RJ 2002/1153, de 06 de novembro de 2002 (Caso Previ-Sistel) . Disponível em http://www.cvm.gov.br/port/inqueritos/2002/TARJ2002_1153.asp. Acesso em 28 de maio de 2009.

Acórdão proferido nos autos do Processo CVM RJ 2009/5811, de 28 de julho de 2009 (Caso Duratex-Satipel). Disponível em HTTP://www.cvm.gov.br/port/descol/resp.asp?File=2009-028D28072009.htm. Acesso em $06 / 11 / 2009$

Acórdão proferido nos autos do Processo CVM RJ 2009/4691, de 11 de agosto de 2009 (Caso Sadia-Perdigão). HTTP://www.cvm.gov.br/port/descol/resp.asp?File=2009-030D11082009.htm. Acesso em $06 / 11 / 2009$

Acórdão proferido nos autos do Processo Administrativo $n^{o}$ RJ 2009-13179, de 9 de setembro de 2010 (Caso Tractebel). Disponível em http://www.cvm.gov.br/port/descol/respdecis.asp?File=7190-4.HTM. Acesso em 19/07/2011.

Parecer de Orientação CVM $n^{\circ} 34$, de 18 de agosto de 2006 - Impedimento de voto em casos de benefício particular em operações de incorporação e incorporação de ações em que sejam atribuídos diferentes valores para as ações de emissão da companhia envolvida na operação, conforme sua espécie, classe ou titularidade. Interpretação do $\S^{\circ}$ do art. 115 da Lei 6404/76. Disponível em http://www.cvm.gov.br/asp/cvmwww/atos/exiato.asp?File=/pare/pare034.htm. Acesso em 19/07/2011. 
Acórdão proferido nos autos do Inquérito Administrativo $n^{\circ}$ RJ 2001/4977, de 19 de dezembro de 2001 (Caso Tele Sul Participações). Disponível em http://www.cvm.gov.br/port/inqueritos/2001/rordinario/inqueritos/4977.asp. Acesso em 19/07/2011.

Acórdão proferido nos autos do Processo Administrativo $n^{o}$ RJ 2004/5494, de 16 de dezembro de 2004 (Caso Ambev). Disponível em http://www.cvm.gov.br/port/descol/respdecis.asp?File=4483-0.HTM. Acesso em 19/07/2011.

Acórdão proferido nos autos do Processo Administrativo $n^{o}$ RJ 2007-3453, de 2 de outubro de 2007 (Caso Fertifós-Fosfértil)). Disponível em http://www.cvm.gov.br/port/descol/respdecis.asp?File=5471-3.HTM. Acesso em 19/07/2011.

. Acórdão proferido nos autos do Processo

Administrativo $n^{o}$ RJ 2007/8844, de 22 de julho de 2008 (Caso MG Poliéster). Disponível em http://www.cvm.gov.br/port/inqueritos/2009/rordinario/inqueritos/TA\%20RJ20081815\%20Mossi\%20\&\%20Chisolfi\%20Internacional.asp. Acesso em 19/07/2011.

Acórdão proferido nos autos do Processo Administrativo $n^{o}$ RJ 2011/4394, de 26 de abril de 2011 (Caso Vivo-Telesp). Disponível em http://www.cvm.gov.br/port/descol/respdecis.asp?File=7676-1.HTM. Acesso em 05/05/2012.

Acórdão proferido nos autos do Processo Administrativo $n^{\circ}$ RJ 2004/5580, de 17 de dezembro de 2005 (Caso Cemar). Disponível em http://www.cvm.gov.br/port/descol/respdecis.asp?File=4933-0.HTM Acesso em 19/07/2011.

Acórdão proferido nos autos do Processo Administrativo $n^{o}$ RJ 2005/4505, de 22 de julho de 2008 (Caso Sabin). Disponível 
emhttp://www.cvm.gov.br/port/descol/respdecis.asp?File=5151-2.HTM. Acesso em 19/07/2011.

Acórdão proferido nos autos do Processo Administrativo $n^{o}$ RJ 2011/9011, de 16 de fevereiro de 2012 (Caso Oi). Disponível em http://www.cvm.gov.br/port/descol/respdecis.asp?File=8111-0.HTM. Acesso em 05/05/2012.

COMPARATO, Fábio Konder. Controle Conjunto, Abuso no exercício do Voto Acionário e Alienação Indireta de Controle Empresarial In: Direito Empresarial: Estudos e Pareceres, $2^{\mathrm{a}}$ tiragem, São Paulo: Saraiva, 1995.

.O Poder de Controle na Sociedade Anônima. Rio de Janeiro:

Forense, 2008.

Aspectos Jurídicos da Macro Empresa. São Paulo, RT, 1970.

COZIAN, M., VIANDIER, A. e DEBOISSY, F. Droit des Sociétés, 15 ed. Paris: LexisNexis, 2006.

COSTA, Philomeno J . Anotações às companhias. São Paulo: Revista dos Tribunais, 1980.

CUNHA, Rodrigo Ferraz Pimenta. Estrutura de Interesses nas Sociedades Anônimas. São Paulo, Quartier Latin, 2007.

CUNHA PEIXOTO, Carlos Fulgêncio da. Sociedades por Ações, v. III, São Paulo: Saraiva, 1973.

DYCK, Alexander e ZINGALES, Luigi. Private Benefits of Control: An International Comparison. The Journal of Finance, v. LIX, n. 2, p. 1-45, abril/2004. 
EIZIRIK, Nelson. Incorporação de Ações: Aspectos Polêmicos. In: Ward Jr. Walfrido Jorge (Coord.). Fusão, Cisão, Incorporação e Temas Correlatos. São Paulo: Quartier Latin, 2009.

FIUZA, Ricardo (Coord). Novo Código Civil Comentado, $5^{\mathrm{a}}$ ed. São Paulo: Saraiva, 2006.

FERRAZ JR. Tércio Sampaio. Introdução ao Estudo do Direito: Técnica, Decisão, Dominação, 3 ed. São Paulo: Atlas, 2001.

FERRI, Giuseppe. La Tutella della Minoranze Nella Società per Azioni. Padova: CEDAM, 1932.

FRANÇA, Erasmo Valladão e Novaes. O Conceito de Benefício Particular e o Parecer de Orientação 34 da CVM In.: Temas de Direito Societário, Falimentar e Teoria da Empresa. São Paulo: Malheiros, 2009.

Ainda o conceito de benefício particular: anotações ao julgamento do processo CVM n. RJ 2009/5811. Revista de Direito Mercantil, Industrial, Econômico e Financeiro n. 149/150, ano XLVII (Nova Série), p. 293-322, jan/dez 2008.

. Acionista Controlador- impedimento ao direito de voto. Revista de Direito Mercantil, n. 125, São Paulo, Ano XLI (Nova Série), p. 139/172, jan/mar 2002. . Conflito de Interesse: Formal ou Substancial? Nova Decisão da CVM sobre a questão. Revista de Direito Mercantil, n. 128, São Paulo, Ano XLI (Nova Série), p. 225/262, out/dez 2002.

Assembléias das S/A. São Paulo: Malheiros, 1999. 
Conflito de Interesses nas Assembléias de Sociedades Anônimas.São Paulo: Malheiros, 1993.

Lineamento da Reforma do Direito Societário Italiano em Matéria de Invalidade das Deliberações Assembleares. Revista de Direito Mercantil, n. 134, São Paulo, Ano XLIII (Nova Série), p. 12/24 abr/jun 2004.

FREITAS, Juarez. A interpretação sistemática do direito. São Paulo: Malheiros, 2002.

GALGANO, Francesco.; GENGHINI, Ricardo. Il Nuovo Diritto Societario: Le nouve società di capitalli e cooperative, tomo I, Milão: CEDAM, 2006

GUERREIRO, José Alexandre Tavares. Conflitos de Interesse entre Sociedade Controladora e Controlada e entre Coligadas no Exercício do Voto em Assembleias Gerais e Reuniões Sociais. Revista de Direito Mercantil, n. 51, p. 29-32, jul-set/83.

Sociedade Anônima: Poder e Dominação. Revista de Direito Mercantil, Industrial, Econômico e Financeiro, n. 53, p. 72-80, jan-mar de 1984.

Sociologia do Poder nas Sociedades Anônimas. Revista de Direito Mercantil, Industrial, Econômico e Financeiro, n. 77, p. 50-56, jan-mar de 1990.

GOMES, Orlando. Introdução ao Código Civil, 12a ed. Rio de Janeiro: Forense, 1996.

HERZFELDER, F. La protection de la société anonyme contre des abus de vote en cas de conflits d'intérêts en droit allemand. Tradução para o francês de Jean Escarra e Roger Houin. Revue Trimestrielle de Droit Commercial, tomo XXI, Paris: Librairie Sirey, 1968. 
HWANG, Joo Ho. Whose Private Benefits of Control? Owners or Managers? Agosto de 2004, disponível em www.fdic.gov/bank/analytical/CFR/2004/sept/CFRCP_2004-03hwang.pdf.

HOLMEN, Martin e KNOPF, John. D. Minority Shareholder Protections and the Private Benefits of Control for Swedish Mergers. Journal of Financial and Comparative Analysis, v. 39, n. 1, p. 167-191, março/2004.

IHERING, Rudolph. Law as a Means to na End. Boston: The Boston G.C., 1913.

JAEGER, Pier Giusto.; DENOZZA, Francesco. Appunti di Diritto Commerciale: Impresa e Società. Milano: Giufré, 2000.

JAEGER, P.G. L’Interesse Sociale, Milano: Giuffré, 1972

KELSEN, Hans. Teoria Pura do Direito. São Paulo: Martins, 2000

LEÃES, Luiz Gastão Paes de Barros. Proibição de Voto e Conflito de Interesses nas Assembléias Gerais. In.: Pareceres. São Paulo: Singular, 2004.

Conflito de Interesses In.: Estudos e Pareceres sobre

Sociedades Anônimas. São Paulo: RT, 1989.

Incorporação de companhia controlada. Revista de

Direito Mercantil, São Paulo: RT, v.94, p.87-96, abr-jun 1994.

LODI, João Bosco. Governança Corporativa: O Governo da Empresa e o Conselho de Administração. Rio de Janeiro: Campus, 2000.

MAGALHÃES, Roberto Barcellos. A Nova Lei das Sociedades por Ações Comentada. v. II e III Rio de Janeiro: Freitas Bastos, 1977. 
MARTINS, Fran. Comentários à Lei das S/A, v. II, Tomo 1, $2^{\mathrm{a}}$ Ed. Rio de Janeiro: Forense, 1984.

Comentários à Lei das Sociedades Anônimas: Artigo por artigo, $4^{\mathrm{a}}$ Ed.

Rio de Janeiro: Forense, 2010.

MENGONI, Luigi. Appunti per uma revisione della teoria sul conflitto di interessi nelle deliberazioni di assemblea della società per azioni. Rivista Delle Società, ano I, p. 434-464, 1956

MIRANDA VALVERDE, Trajano de Miranda. Sociedade por Ações, v. I e II, 2. ed. Rio de Janeiro: Forense, 1953.

MUNHOZ, Eduardo Secchi. Contribuições para Revisão do Modelo Societário, 2002. Tese apresentada à Universidade de São Paulo para a obtenção do título de Doutor em Direito Comercial.

NASCIMENTO, João Paulo Barroso. Conflito de Interesses no Exercício do Direito de Voto nas Sociedades Anônimas (2 ${ }^{\mathrm{a}}$ parte). Revista de Direito Bancário, do Mercado de Capitais, n. 25, ano 7, p. 82-103, jul-set 2004.

NUNES, Mercês da Silva. Abuso do Direito de Voto e Conflito de Interesses. In: VIDIGAL, Geraldo de Camargo; MARTINS, Ives Gandra da Silva (Coords). Comentários à Lei das Sociedades por ações: Lei 6404/76. São Paulo: Resenha Universitária: Instituto dos Advogados de São Paulo, 1978.

NUSDEO, F. Curso de Economia - Introdução ao estudo do direito econômico. $2^{\mathrm{a}}$ Ed. São Paulo: RT, 2000.

PAPINI, Roberto. Sociedade Anônima e mercado de valores mobiliários. Rio de Janeiro: Forense, 1987. 
PONTES, Aloysio Lopes. Sociedades Anônimas, 3. ed. Rio de Janeiro: Forense, 1954.

PENTEADO, Mauro Rodrigues. Aumento de Capitais nas Sociedades por Ações. Tese apresentada ao Departamento de Direito Comercail da Universidade de São Paulo para obtenção do título de Doutor em Direito, 1896.

PENTEADO JR., Cássio. A disciplina da abstenção do voto ma legislação das S.A. In: Vidigal, Geraldo de Camargo e Martins, Ives Gandra (Coords). Sociedade por Ações - Estudo n. 20. São Paulo: Resenha Universitária, 1981.

PONTES DE MIRANDA, Francisco Cavalcanti. Tratado de Direito Privado, V. I. São Paulo: RT, 1983.

RIBEIRO, Renato Ventura. Direito de Voto nas Sociedades Anônimas. São Paulo: Quartier Latin, 2009.

RIVIÈRE, Hippolyte Féréol. Commentaires sur la Loi 24 de juillet de 1867 sur las Sociétes. Paris: A.Marescq Ainé, 1868.

ROJAS JR, Luis Manuel. El Derecho de Voto em La Sociedad Anônima. México: Ed Jus, 1945.

SALOMÃO Fo, Calixto. O Novo Direito Societário, $4^{\mathrm{a}}$ ed. São Paulo: Malheiros, 2011.

SCHMIDT, Dominique. Le Conflits d'Intérêts dans La Société Anonyme. Paris: Joly, 1999. Le Droits de La Minorité das La Société Anonymme. Paris: Sirey, 1970. 
SENA, Giuseppe. Il Voto nella Assemblea della Societá per Azioni. Milano: Dott.A.Giuffre Editore, 1958.

SILVA, De Plácido e. Vocabulário Jurídico. V.III. Rio de Janeiro: Forense. 1989.

TEIXEIRA, Egberto Lacerda.; GUERREIRO, José Alexandre Tavares. Das Sociedades Anônimas no Direito Brasileiro. São Paulo, Bushatsky, 1979.

URÍA, Rodrigo. Derecho Mercantil. Madrid : Marcial Pons, 1995.

VIVANTE, Cesare. Tratatto di Diritto Commerciale, v. III, $3^{\text {a }}$ Milano: Francesco Vallardi, ano $\mathrm{n} / \mathrm{d}$.

WALD, Arnold. A Evolução do regime legal do Conselho de Administração, os Acordos de Acionistas e os Impedimentos de Votos dos Conselheiros decorrentes de Conflitos de Interesses. Revista de Direito Bancário, do Mercado de Capitais e da Arbitragem n ${ }^{\circ} 11, \mathrm{p}-13-$ 30, 2001. 